VOLUMINA JURASSICA, 2020, XVIII (2): 161-234

DOI: $10.7306 /$ NJ.18.8

\title{
The Kimmeridgian of the south-western margin of the Holy Cross Mts., central Poland: stratigraphy and facies development. Part I. From deep-neritic sponge megafacies to shallow water carbonates
}

\author{
Andrzej WIERZBOWSKI ${ }^{1}$
}

Key words: Upper Jurassic, shallow-water carbonates, history of sedimentation, climatic and tectonic factors, lithostratigraphic scheme, comparison with Jura Mts., ammonite phylogeny.

\begin{abstract}
The stratigraphical interval of the Kimmeridgian between the Bimammatum and the Hypselocylum zones in the SW margin of the Holy Cross Mts. shows a transition from the open shelf deep-neritic sponge megafacies to the shallow-water carbonate platform, including its development and decline. The uniform progradation of the shallow-water carbonate platform occurred at the end of the Planula Chron. Development of the shallow-water carbonate platform was controlled by climatic and tectonic factors. The former induced by orbital cyclicity resulted in changes of sea-level, revealed i.a. by the incoming of open-marine ammonite faunas, the latter were related to the synsedimentary activity of faults which resulted in contrasted facies changes. The episodically occurring strong influx of siliciclastic material was at least partly controlled by the tectonic activity. The newly elaborated formal lithostratigraphic subdivision takes into account the facies development of the succession in relation to climatically and tectonically induced changes. Such is e.g. the Małogoszcz Oolite Formation, corresponding to a single 100-kyr eccentricity cycle from the late Platynota Chron to the earliest Hypselocyclum Chron, bordered from the base and top by two transgressive climatically-controlled levels. The final stage of the shallow-water platform development at the end of the Hypselocyclum Chron was marked by the successive limitation of restricted environments, and the appearance of more openmarine conditions related to tectonic subsidence of the area of study. Comparison between the carbonate platform development of the Holy Cross Mts. in central Poland, and the coeval shallow-water carbonates of the Jura Mts. in northern Switzerland and south-eastern France provides an opportunity to consider similarities in the successions which can be attributed to the climatically-controlled sedimentary cyclicity and/or the wide-ranged tectonic phenomena. The palaeontological part of the study gives comments on the classification and phylogeny of ammonites of the families Ataxioceratidae and Aulacostephanidae.
\end{abstract}

\section{INTRODUCTION}

The Kimmeridgian deposits occurring at the margins of the Holy Cross Mountains represent remnants of the Jurassic cover developed originally over the whole area of the mountains, including its Palaeozoic core, but subsequently partly removed due to Neo-Cimmerian (pre-Albian), and especially Laramian tectonic movements at the end of the
Maastrichtian and during the Palaeocene (Kutek, Głazek, 1972). The Jurassic actually preserved, including the Kimmeridgian deposits which are discussed here, in the southwestern, the north-western and the north-eastern margins of the Holy Cross Mts., differs partly in the completeness of its succession, and in type of its facies (see e.g. Kutek, 1968, 1969, 1994; Gutowski, 1992, 1998; Matyja, 2011; Matyja, Wierzbowski, 2014). There are also regional differences in

\footnotetext{
${ }^{1}$ University of Warsaw, Faculty of Geology, Żwirki i Wigury 93, PL 02-089 Warszawa, Poland; andrzej.wierzbowski@uw.edu.pl.
} 
the style of the tectonic deformations (Kutek, Głazek, 1972). The Jurassic deposits in the south-western margin are folded and usually dip gently at a few up to $20^{\circ}$, but are locally steeply inclined or even vertical, at the limbs of the relatively densely spaced anticlines and synclines generally stretching in a NW-SE direction (see e.g. Kutek, 1968, fig. 1).

The aim of this study is to present a general outline of the stratigraphy, facies development and history of sedimentation of the Kimmeridgian in the south-western margin of the Holy Cross Mountains. The first attempt to classify lithostratigraphically the Kimmeridgian deposits (referred at that time to the "Astartian" and "Kimmeridgian") in the area was made by Świdziński (1962). The "facies-lithological complexes" described by him roughly correspond to the herein distinguished formations. The classical study of the Kimmeridgian deposits of the south-western margin of the Holy Cross Mts., their stratigraphy and palaeogeography, was presented by Kutek $(1968,1969)$ with lithofacies descriptions supplemented by Pszczółkowski (1970). Although becoming the most comprehensive description of these rocks in the area, some of the interpretations given therein nowadays need modification. This results from general progress in detailed ammonite stratigraphy, such as the appearance of the new stratigraphical subdivisions of the Kimmeridgian based on the evolution of the ammonite family Ataxioceratidae (Atrops, 1982), but also because of the opening of new extensive quarries, including e.g. the cement-works quarry at Małogoszcz, which have provided large collections of ammonites and offered new data on the facies development and interpretation of the palaeogeography (see e.g. Matyja et al., 2006a).

The Kimmeridgian, as treated herein, corresponds to the stratigraphical interval from the base of the ammonite Baylei Zone in the Subboreal zonal scheme (and the corresponding Bauhini Zone in the Boreal scheme), which is the base of the uniform Kimmeridgian Stage as proposed by the Kimmeridgian Working Group and recently accepted by the International Subcommision on Jurassic Stratigraphy of the International Union of Geological Sciences. This boundary, corresponding to the base of the ammonite Bimammatum Zone (and the base of the Bimammatum Subzone) in the Submediterranean zonal scheme, runs markedly lower than the formerly accepted lower boundary of this stage in the area of study (and in the Submediterranean Province as a whole). In consequence of such a stratigraphical interpretation, the deposits of the Submediterranean Planula Zone, and the Bimammatum Zone, previously correlated with the Upper Oxfordian, become included in the Kimmeridgian Stage (see Matyja et al., 2006b; Wierzbowski A. et al., 2016, 2018). The present study thus treats the Kimmeridgian Stage according to the actually proposed uniform European (and world-wide) definition with the base of the stage ranging stratigraphically markedly below the base of the Kimmeridgian as interpreted formerly, and thus below the uppermost Oxfordian correlated with a part of the Planula Zone, as interpreted in the south-western margin of the Holy Cross Mts. by Kutek (1968). The Kimmeridgian, as accepted herein, includes also a part of the older deposits occurring in the south-western margin of the Holy Cross Mts., correlated with the Planula Zone and the Bimammatum Zone (down to the base of the Bimammatum Subzone) described by Matyja (1977) and Matyja et al. (1989). On the other hand, the succession of the youngest deposits of the Kimmeridgian in the south-western margin of the Holy Cross Mts. is not complete, although it ranges through the Mutabilis Zone and at least a part of the Eudoxus Zone of the lower part of the Upper Kimmeridgian. This is because of the pre-Albian erosion of the youngest Jurassic (and the oldest Early Cretaceous deposits) due to the Neo-Cimmerian tectonic movements in that area (Kutek, 1968, 1994).

This paper is devoted to the Lower Kimmeridgian deposits from the open shelf deep-neritic sponge megafacies to the succeeding shallow-water carbonate facies in the southwestern margin of the Holy Cross Mountains. These represent the fragments of the transgressive-regressive sequence recognized in the territory of Poland by Kutek (1994) as the COK (Callovian-Oxfordian-Kimmeridgian) sequence. The shallow-water carbonate deposits of the regressive part of the sequence are considered as representative of the shallowwater carbonate platform, which is regarded herein as a zone of shelf covered by carbonate deposits formed above or close to wave base (cf. Matyja et al., 1989, p. 34). When compared with holistic problematics of the carbonate platform deposits in south-eastern Poland, including the stratigraphical interval from Middle Oxfordian to Lower Kimmeridgian, the subject of this study as related to the Lower Kimmeridgian from the Bimammatum Zone to the Hypselocyclum Zone in the south-western margin of the Holy Cross Mts. only, is limited in its extent. Nevertheless, because of good exposures, long history of investigation and fairly abundant ammonites, the studied Lower Kimmeridgian succession provides an ideal opportunity to discuss also some general concepts concerning the development of the discussed shallow-water carbonate platform. The overlying uppermost Lower and lowermost Upper Kimmeridgian deposits formed after the decline of the shallow-water platform, mark the beginning of the next transgressive-regressive sequence LUK (LowerUpper Kimmeridgian) (Kutek, 1994), and will be described separately, in the second part of the study, published elsewhere.

The present study includes the area from the southernmost occurrences of the Kimmeridgian deposits at Korytnica and Celiny, and north-eastwards up to Bukowa quarry, Gruszczyn, Rogalin and Oleszno (see Kutek, 1968; Pszczółkowski, 1970; see also Figs. 1, 2). This area repre- 


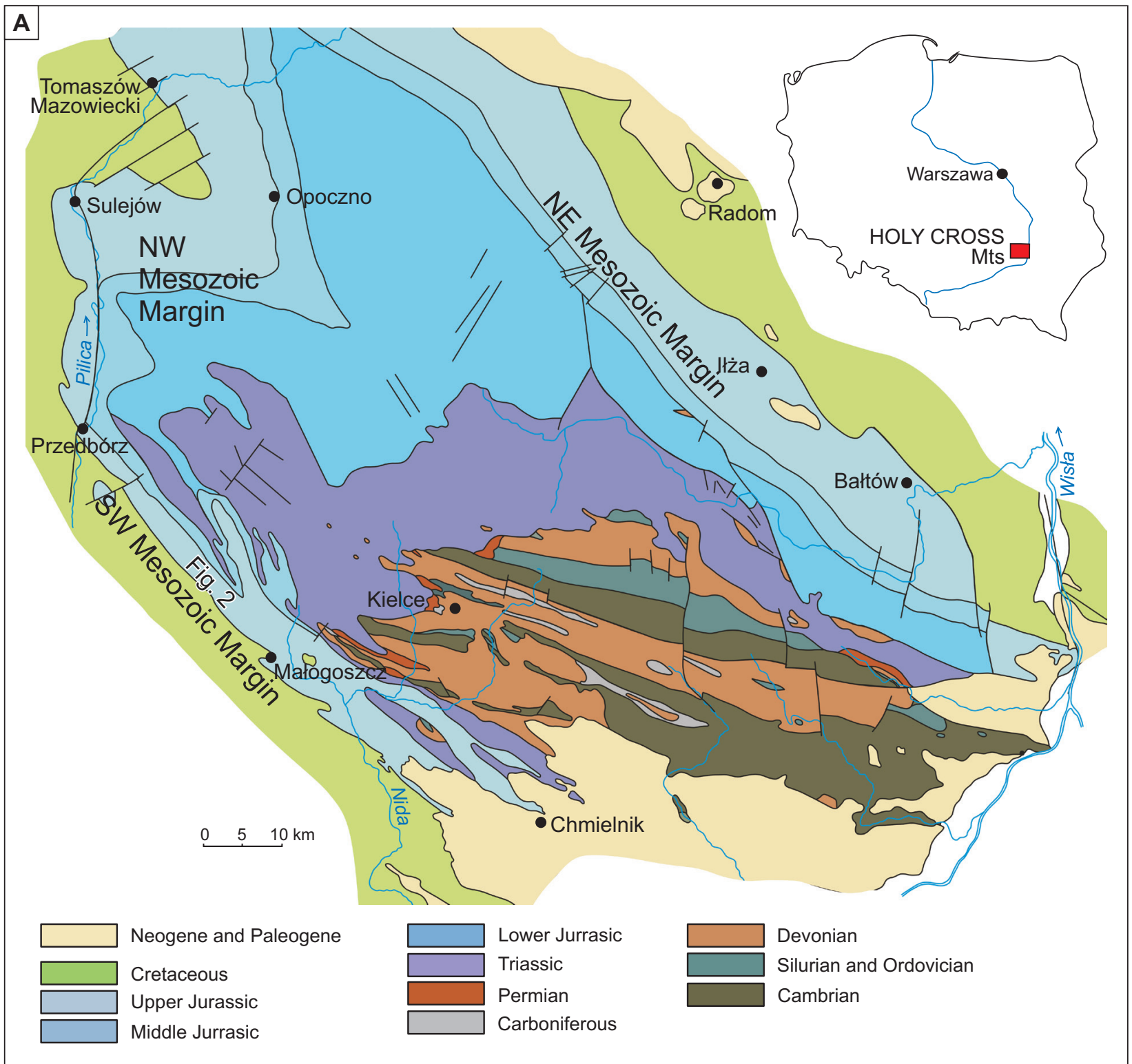

Fig. 1. Geological sketch-map of the Holy Cross Mts. (after Samsonowicz in: Książkiewicz, Samsonowicz, 1953; somewhat modified), showing the main tectonic units and the study area

sents the fairly uniform development of the succession typical of the south-western margin of the Holy Cross Mts., which differs in some aspects of that recognized between Dobromierz and Przedbórz to the north-west (Świdziński, 1962; Kutek, 1968). The latter area together with the nearby area of Sulejów and Tomaszów Mazowiecki of the northwestern margin of the Holy Cross Mts. corresponds already to another facies region and will be described elsewhere.

There exist a number of papers discussing facies and faunal approaches to selected carbonate deposits making up the succession studied in the south-western margin of the Holy Cross Mts. The bulk of them were published after the appearance of the studies of Kutek $(1968,1969)$ and Pszczółkowski (1970). They provide some new observation on the facies development of the succession, but mostly lack detailed new age-correlation based on the analysis of ammonite assemblages important for chronostratigraphy, except the studies of Matyja (1977) and Matyja et al. (1989). The interpretations given therein are commented on below, both when they have supplemented the general knowledge of the succession and 


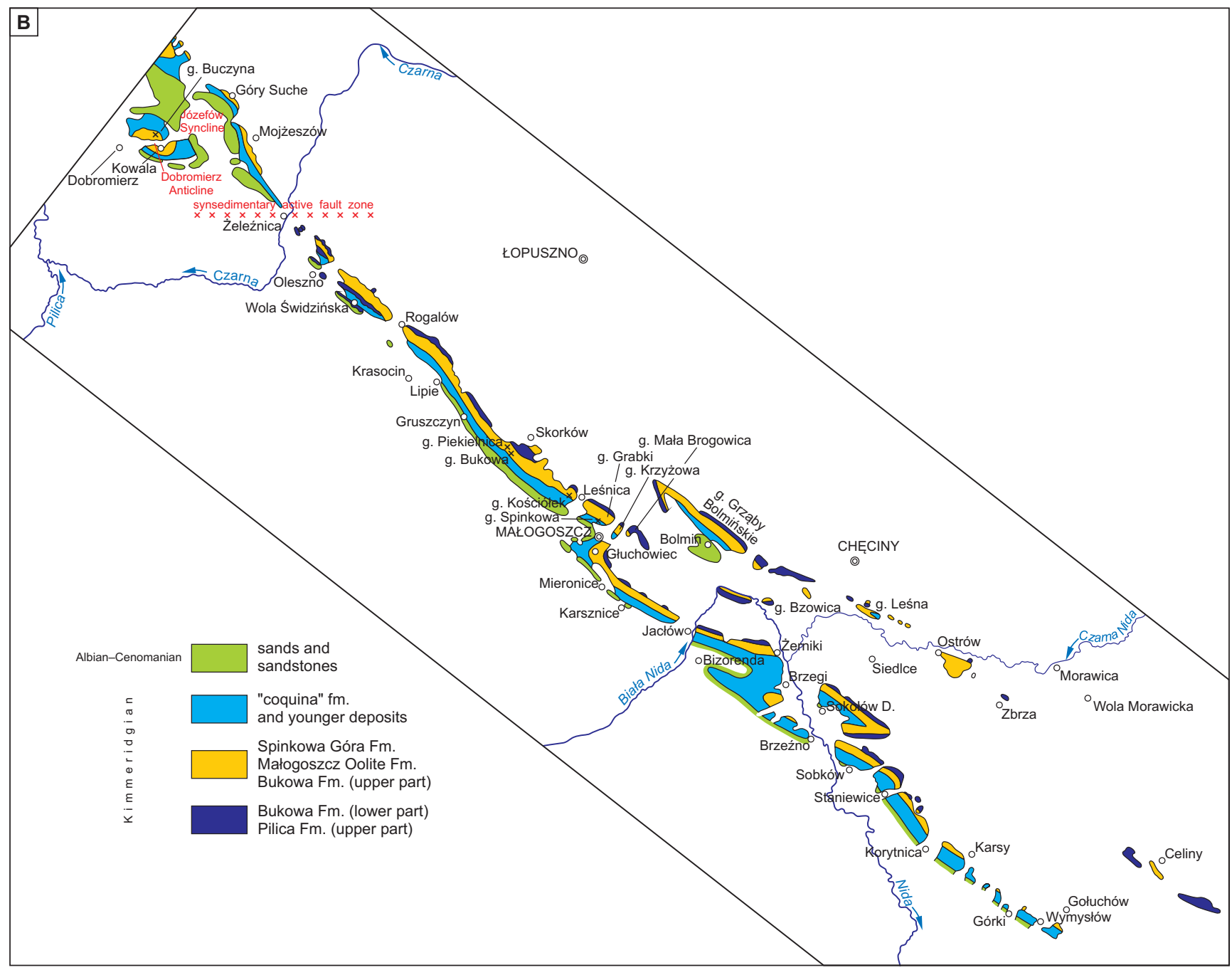

Fig. 2. Map of occurrences of the Kimmeridgian deposits in the south-western margin of the Holy Cross Mts. (after Kutek, 1968, somewhat modified and stratigraphically revised)

The lithostratigraphical units of the Kimmeridgian are reinterpreted according to the classification given herein as follows, with the original names of Kutek (1968) in brackets: "coquina" formation and younger marly units ("marly-lumachelle deposits"); Spinkowa Góra Fm., Małogoszcz Oolite Fm., and upper part of Bukowa Fm. ("oolite-platy deposits"); lower part of Bukowa Fm. and upper part of Pilica Fm. ("chalky limestone member"). The tectonic features discussed in the text are marked in red. Abbreviations: g. (góra in Polish) - hill

facies development, but also in cases when they differ markedly from the opinion of the present author.

The description of the lithostratigraphical succession as given herein needs formal recognition of new lithostratigraphic units, both of formation rank, as well as of a lower category rank (like members and beds). The lithostratigraphical subdivision of the deposits takes into account older informal units - such as those proposed (or repeated from older publications) by Świdziński (1962), Kutek (1968), Matyja $(1977,2011)$ and Matyja et al. (1989) - but it is also based on proposals given in other papers - by Dembowska (1979), Matyja, Wierzbowski $(2004,2014)$ and Wierzbowski (2017a) - all of them coming from regions placed west and north-west of the area of study. The new lithostratigraphical units are described in detail in Appendix 1 attached to this study.

Although the palaeontology of ammonites has not been the main subject of this study, some comments on the palaeontological interpretation of the ammonites as well as their classification and phylogeny are given in Appendix 2. 


\section{FACIES SUCCESSION AND ITS LITHOSTRATIGRAPHICAL AND BIOCHRONOSTRATIGRAPHICAL INTERPRETATION}

Deposits of the sponge megafacies underlying the Kimmeridgian. The oldest Late Jurassic deposits of the south-western margin of the Holy Cross Mts. belong to the so called sponge megafacies and are represented by carbonates (limestones, less commonly marls) rich in siliceous sponges (preserved as sponge mummies) - Lithistida and Hyalospongea (Hexactinosa and Lychnicosa), and other benthic (brachiopods, bryozoans, serpulids) as well as nektonic fossils (ammonites, belemnites). These deposits, mostly correlated with the Oxfordian Stage, are developed as well-bedded limestones (subordinately also marls) with cherts (called the Morawica limestones) laterally replacing massive biohermal limestones, both corresponding to the Częstochowa Sponge Limestone Formation (Matyja, 1977; Matyja, Wierzbowski, 2004). This facies pattern has resulted in a highly diversified original relief of the sea bottom ranging up to about 150-200 meters between the top of the sponge-cyanobacteria bioherms (or bioherm complexes) composed of massive limestones and the bottom of the interbiohermal basins, where the bedded deposits were formed (Matyja, Wierzbowski, 1996; see also Matyja, 1977).

Pilica Formation (micritic limestones with grainstone intercalations): Hypselum to Planula zones. Youngest are well-bedded micritic limestones with a poor benthic fauna (only locally does their lowermost part still contain some fauna), showing enormous development within basinal areas when resting on the well-bedded sponge limestones, and attaining there more than $450 \mathrm{~m}$ (Matyja, 1977) and even up to $535 \mathrm{~m}$ in thickness (Matyja et al., 1989; Fig. 3). These micritic limestones crop out in several quarries like WolicaSiedlce quarry and Wierzbica-Sobków quarry in the western margin of the Holy Cross Mts. area, and were called the Siedlce limestones (Matyja, 1977) and recognized later (Matyja et al., 1989) as the Siedlce Limestone Member. They are placed in the Pilica Formation as distinguished formally in the area of the Polish Jura by Matyja and Wierzbowski (2004).

A very characteristic set of deposits, composed of three distinct marly layers (from some tens of centimeters to about $1.50 \mathrm{~m}$ in thickness) occurring within a limestone succession in a lower part of the Siedlce Limestone Member, and ranging up to about 15 meters in thickness, can be recognized in the south-western margin of the Holy Cross Mts. It is distinguished herein as the Wolica Bed (Fig. 3; see Appendix 1). This lithostratigraphic unit occurs about 190$205 \mathrm{~m}$ above the base of the Upper Jurassic deposits in the

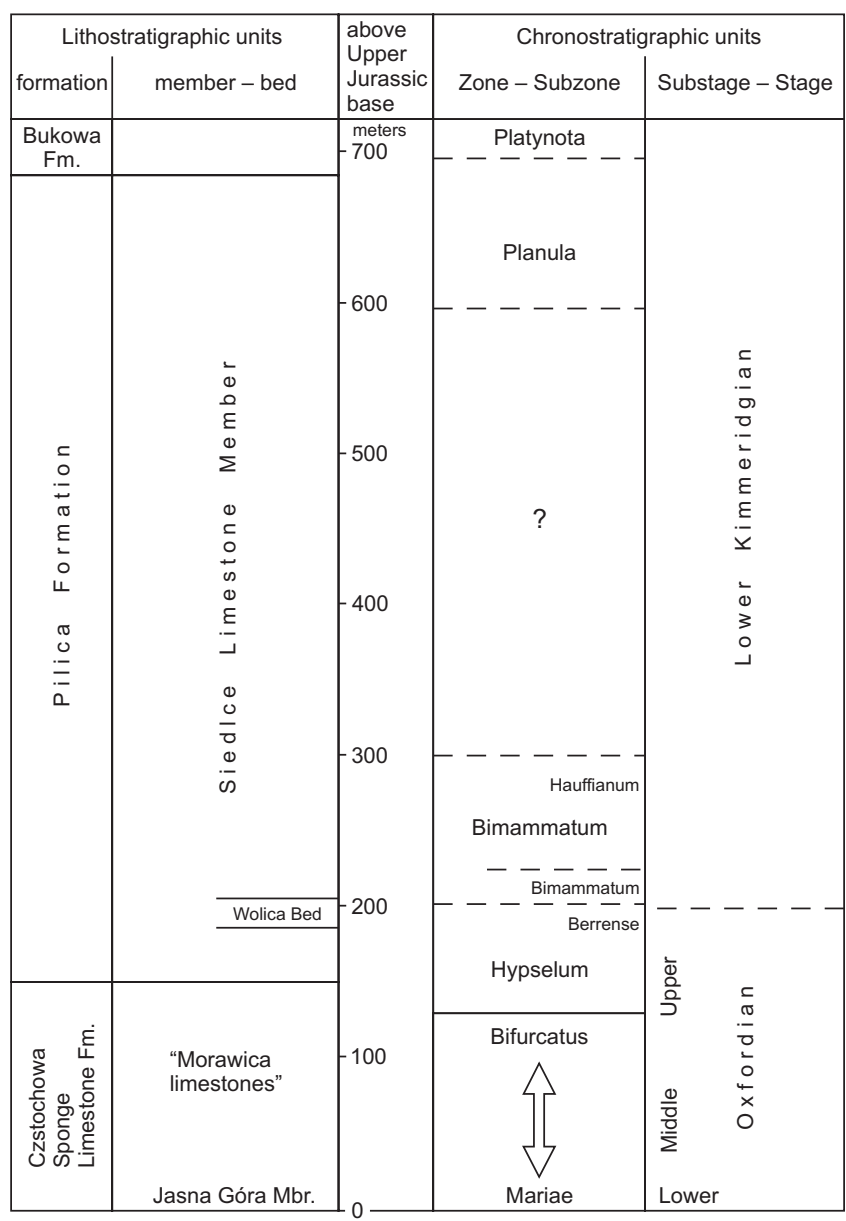

Fig. 3. Stratigraphy of the Oxfordian and lowest Kimmeridgian at the transition from deep-neritic sponge magafacies to shallow-water carbonate platform deposits in the Siedlce to Sobków-Wierzbica area in the south-western margin of the Holy Cross Mountains (after Matyja, 1977 and Matyja et al., 1989; somewhat modified)

basinal areas (such as the Wolica-Siedlce, the Wolica, and the Morawica sections), and climbs up to about $390 \mathrm{~m}$ above the same level in the bioherm complexes, including sections at Krasnowicka hill, and Nida-Brzeziny - thus, its position differs about $200 \mathrm{~m}$ in height between the two areas and corresponds to the original relief of the sea-bottom (Matyja, 1977, fig. 4; cf. Matyja, Wierzbowski, 1996).

The ammonite fauna composed of small-sized ammonites was found mostly in the rubble close to the Wolica Bed. It includes (Matyja, 1977, 2011; see also Matyja et al., 1989, fig. 4) very common oppeliids, constituting about $80 \%$ of the whole assemblage; some of them may be grouped in dimorphic pairs (see Wierzbowski et al., 2010), such as Taramelliceras (Taramelliceras) costatum (Quenstedt) (see Matyja, 1977, pl. 3: 14-18) and Glochiceras (Lin- 
gulaticeras) bobrownikiense Wierzbowski et Głowniak (originally interpreted by Matyja, 1977 as G. lingulatum); but also not strictly related - Ochetoceras (Ochetoceras) marantianum (d'Orbigny) (see Matyja, 1977, pl. 2: 4-6); Glochiceras (Coryceras) canale (Oppel). Additionally, some ammonites belonging to other groups were also found here. These include phylloceratids, such as Sowerbyceras tortisulcatum (d'Orbigny) (see Matyja, 1977, pl. 1: 1) and small aulacostephanids originally interpreted as "Ringsteadia flexuoides (Quenstedt)" (see Matyja, 1977, pl. 8: 6), which are similar to the later founded genus Vielunia (see Wierzbowski et al., 2010). The whole assemblage is very remarkable, because it is close in composition to that described from the Bobrowniki section in the Wielun Upland, having a well-established stratigraphical position near the Oxfordian/Kimmeridgian boundary (see Wierzbowski et al., 2010, 2016; Wierzbowski, Matyja, 2014). The occurrence of the oppeliids as mentioned above, including the presence of the subspecies Taramelliceras (Taramelliceras) costatum laterinodosum Karvé-Corvinus, which possibly includes some of the specimens of $T$. costatum illustrated by Matyja (1977, pl. 3: 14-16), the occurrence of $O$. marantianum showing a high point of rib furcation, but also the presence of aulacostephanids, possibly related to Vielunia dzalosinensis Wierzbowski et Głowniak ( $c f$. immature specimen of the species illustrated in: Wierzbowski et al., 2010, pl. 9: 4 with that illustrated by Matyja, 1977, pl. 8: 6) strongly suggest the correlation of the discussed fauna (or at least a part of it) with that of the lowermost Kimmeridgian in the Bobrowniki section. Moreover, the marly deposits occur in the Bobrowniki section commonly below the Oxfordian/Kimmeridgian boundary, near the boundary between the Berrense Subzone of the topmost part of the Hypselum Zone, and the Bimammatum Subzone of the Bimammatum Zone ( $c f$. Wierzbowski, Matyja, 2014; Wierzbowski et al., 2016), thus showing some lithological similarity to the Wolica Bed. All these data indicate that the base of the Kimmeridgian Stage as interpreted according to the proposal of the International Subcommission on Jurassic Stratigraphy (see Wierzbowski A. et al., 2016, 2018) runs within or directly above the Wolica Bed in the lower part of the Siedlce Limestone Member of the Pilica Formation (Fig. 3) in the south-western margin of the Holy Cross Mts.

A younger faunal assemblage found about 20 meters above the Wolica Bed in the Wolica and Wolica-Siedlce sections is also composed of several oppeliids, which are partly similar to those mentioned above: Taramelliceras $(T$.) costatum (Quenstedt), Glochiceras (Lingulaticeras) bobrownikiense Wierzbowski et Głowniak, but some are new: Glochiceras (G.) cf. tectum Ziegler, Glochiceras (Coryceras) modestiforme (Oppel) and Taramelliceras (Richeiceras) pichleri (Oppel) (see Matyja, 1977, pl. 1: 4, 5; pl. 3: 19; see also Matyja et al., 1989, fig. 4). This assemblage is indicative of the Bimammatum Subzone, especially because of the occurrence of T. (T.) costatum (Quenstedt) and T. (R.) pichleri which are both unknown from younger deposits (see Wierzbowski et al., 2010). The only problem is with the ammonite coming from this assemblage and originally (Matyja, 1977, pl. 8: 1) referred to as "? Idoceras aff. minutum Dieterich". It was interpreted as a forerunner of the genus Subnebrodites and was compared with some forms occurring in the Hauffianum Subzone, representing the upper part of the Bimammatum Zone, i.e. in somewhat younger beds that the discussed oppeliid assemblage (Matyja et al., 1989). Moreover, the ammonite in question looks similar to the oldest species of Subnebrodites - S. matyjai Wierzbowski et Głowniak (see Wierzbowski et al., 2010, p. 74, pl. 12: 1, 2) which occurs in the lowermost part of the Planula Zone, differing mostly in lacking a ventral smooth band. The co-occurrence of the discussed form with oppeliids indicative of the Bimammatum Subzone, however, strongly suggests that its stratigraphical position, similar to that of the whole ammonite assemblage, corresponds to the topmost part of the subzone, near the base of the overlying Hauffianum Subzone.

The youngest deposits of the Siedlce Limestone Member of the Pilica Formation show a marked lateral facies differentiation in the western margin of the Holy Cross Mts. The differences are expressed by the local occurrence of layers of oolitic-onkolitic-bioclastic grainstones of shallow-water origin with an abundant benthic fauna, in contrast to the bulk of micritic limestones of the succession being generally very poor in fauna. The study of Sobków-Wierzbica quarry reveals that the succession of the deposits is placed generally outside the main area of inflow of detrital material (grainstone intercalations are recognized in boreholes in the neighboring area), but showing levels with episodic development of rich benthic assemblages, which flourished due to temporary slowing down of carbonate mud sedimentation (Matyja et al., 1989). All these deposits about 100 meters in thickness yielded also abundant ammonites. The most important ones for stratigraphy are representatives of the genus Subnebrodites indicative of the Planula Zone, such as Subnebrodites laxevolutum (Fontannes) (Matyja et al., 1989, pl. 1: 4-7; pl. 2: 1, 2) and S. planula (Hehl) (Matyja et al., 1989, pl. 2: $3,4)$ both indicative of the planula horizon of the upper part of the zone, but also $S$. cf. schroederi (Wegele) (Matyja et al., 1989, pl. 2: 5-7), occurring somewhat above, and suggesting the presence of the minutum $=$ schroederi horizon of the uppermost part of this zone (cf. Schweigert, Callomon, 1997; Wierzbowski et al., 2010; Wierzbowski, 2017a). The occurrences of Orthosphinctes $(O$.) polygyratus (Reinecke) and $O$. (O.) cf. freybergi (Geyer) (Matyja et al., 1989, pl. 1: 1-3) additionally confirms such a stratigraphical interpretation. The deposits representing the uppermost part of the 
Siedlce Limestone Member in Sobków-Wierzbica quarry show a marked discontinuity surface at their top covered with bioclastic-onkolitic-calcirudite grainstones formed in a much shallower environment. The stratigraphical interpretation of these youngest deposits belonging to the newly erected Bukowa Formation is discussed below.

Another development of the upper part of the Siedlce Limestone Member is present in the succession of the large Bukowa quarry near Skorków village. The section of the old part of the quarry was described in several papers (Kutek, 1968; Roniewicz, Roniewicz, 1971; Alexandrowicz, Barwicz-Piskorz, 1974), but the younger part of the succession cropping out in a new part of the quarry was interpreted more recently by Gutowski et al. (2006) and Matyja (2011). The section begins with a 10 meters thick oolite unit (base not exposed) covered by soft, thick-bedded micritic limestone 12 metres thick. The latter represents the typical deposit of the Siedlce Limestone Member, the former possibly a grainstone lens-shaped body embedded within the micritic limestones of this member. The banded chert level occurs in the topmost part of the micritic limestones, while the top of the Siedlce Limestone Member, in a similar manner to the situation in Sobków-Wierzbica quarry, is cut by the discontinuity surface. The overlaying organogenic chalky limestones with a shallow-water benthic fauna rest unconformably (Gutowski et al., 2006) and belong already to the Bukowa Formation (Figs. 3, 4).

It should be remembered that the distinction of the micritic, friable limestones with intercalations of grainstones of the Siedlce Limestone Member of the Pilica Fm. from the friable grainstones rich in shallow-water fauna of the $\mathrm{Bu}-$ kowa Formation, as interpreted herein, was not always possible in the past, when the general succession of these deposits was not studied in detail, and especially when the succession was not fully exposed, being partly observed in the rubble ( $c f$. Kutek, 1968), or interpreted using aerial photographs (cf. Pszczółkowski, 1970). All these deposits were lumped by Kutek (1968) into his "chalky limestone member" attaining locally at least about $100-130 \mathrm{~m}$ in thickness, whose upper and lower boundaries were treated as "obviously heterochronous". A few ammonites from the lower part of this unit included: Subnebrodites sp. [close to S. laxevolutum (Font.) described as Idoceras sp. (Kutek, 1968, p. 514, pl. 8: 2)] and coming from the micritic limestone intercalation in the Żerniki section, as well as Orthosphinctes (Orthosphinctes) polygyratus (Reinecke) referred originally to as "Perisphinctes (Orthosphinctes) cf. pseudobreviceps Wegele" and coming from a "lower part of the chalky limestone member" of the Mała Brogowica section (Kutek, 1968 , p. 514). These ammonites undoubtedly indicate the presence of the Planula Zone and are strictly comparable to the ammonite assemblage from the upper part of the Siedlce
Limestone Member as described from Sobków-Wierzbica quarry by Matyja et al. (1989).

Bukowa Formation (chalky limestones with corals, grainstones, micritic limestones and marls): uppermost Planula to lower/middle Platynota zones. A more detailed subdivision of the "chalky limestone member" sensu Kutek (1968) was proposed by Pszczółkowski (1970, fig. 3), who recognized a horizon placed about $30-35 \mathrm{~m}$ below the top of the "chalky limestones" which is easily traceable in the aerial photographs between Staniewice and Rogalów in the whole studied area of the south-western margin of the Holy Cross Mts. This horizon, called herein "the basal unit", is from a few up to several meters in thickness and shows large differences in its lithological development. It consists (Pszczółkowski, 1970, fig. 3) of marly limestones and micritic limestones at Staniewice, which are replaced by organodetrital limestones, locally with colonies of Codiaceae (Marinella) between Staniewice and the Biała Nida river valley (i.e. at Sobków-Wierzbica quarry) from the south, and then by micritic limestones, locally with corals, and marly limestones and/or marls towards the west (at Mieronice, Leśnica and Skorków - i.e. at Bukowa quarry), and successively by oolitic limestones towards the north-west (at Gruszczyn and Lipie). The position of this lithological unit within the studied successions of Sobków-Wierzbica quarry and Bukowa quarry is directly above the Siedlce Limestone Member of the Pilica Formation, already in the overlying newly established Bukowa Formation. The base of this unit is marked by the prominent discontinuity surface, having a wide geographical distribution, being the boundary of the two formations as treated herein ( $c f$. also Kaźmierczak, Pszczółkowski, 1968, fig. 2; see also Fig. 4).

The regional data suggest eustatic and/or tectonic control of the discussed discontinuity surface and the related origin of the overlying deposits which resulted from "a sudden progradation of the carbonate platform facies on the whole SW area of the Holy Cross Mts. region" (Matyja et al., 1989, p. 41). This phenomenon took part at the end of the Planula Chron as evidenced by the ammonite fauna in the underlying deposits of the Siedlce Limestone Member. It is in full agreement with the local occurrence of micritic limestones with intercalations of marls and/or marly limestones in "the basal unit" as recognized between Mieronice and Skorków and in the Bukowa quarry section (see Pszczółkowski, 1970, fig. 3; Matyja, 2011, fig. 3) as well as in the boreholes at Leśnica (denoted as "mA" by Barwicz-Piskorz, 1995). These deposits may be treated as the fragmentarily preserved equivalents of the Latosówka Marl Member ("lower marly unit" as interpreted in older papers, e.g. Wierzbowski, 1966; see also Matyja, Wierzbowski, 2004), which is completely developed in the Polish Jura, especially the Wieluń Upland, where its stratigraphical positon corre- 


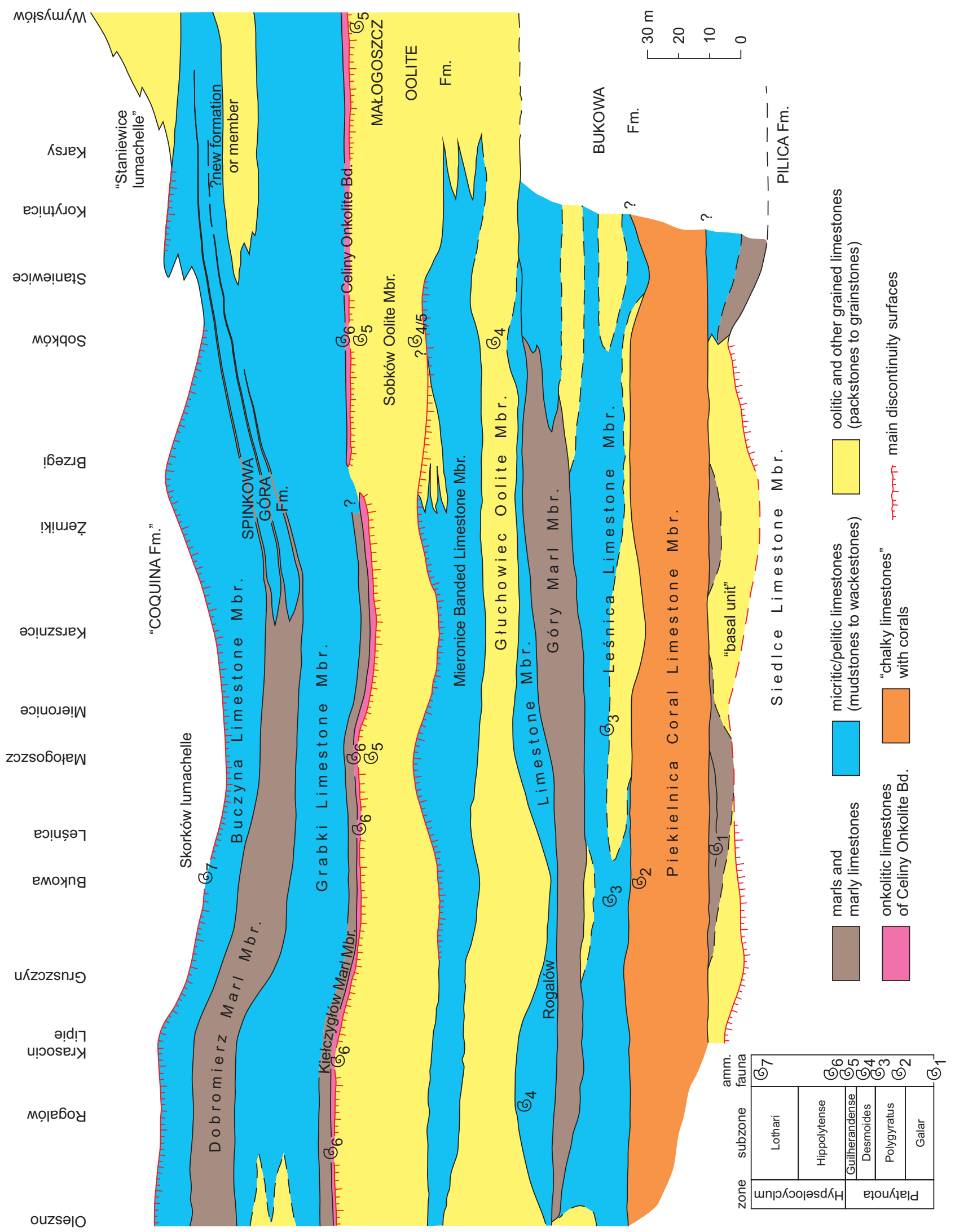


Fig. 4. Lithostratigraphical subdivision and sketch of main facies assemblages of the shallow-water carbonate platform deposits of the Lower Kimmeridgian (uppermost Planula to upper Hypselocyclum zones) in the south-western margin of the Holy Cross Mountains [based on log descriptions of Kutek (1968), Pszczółkowski (1970), Matyja (2011), and other papers cited in the text]

sponds to the topmost part of the Planula Zone (Wierzbowski, 2017a). The ammonites found in the micritic limestones with marly intercalations in the "basal unit" at Bukowa quarry, although not unequivocal in their stratigraphical interpretation, are not contradictory with the suggested stratigraphical correlation of these deposits. They include: (1) "Perisphinctes (Orthosphinctes) sp." (three specimens), localized in the section but not illustrated and lost specimens of Orthosphinctes; they came from "a hard limestone bed between the two chalky limestone units", corresponding to lithostratigraphic unit B6 characterized by the occurrence of bedded limestones with corals and with a marly intercalation (see Kutek, 1968, p. 514, tab. 2, fig. 7); (2) a large specimen (about $280 \mathrm{~mm}$ in diameter) of a nearly smooth aulacostephanid representing either Vineta, or a weakly ornamented Vielunia found by the author and photographed in the field.

The Bukowa Formation as recognized herein (Fig. 4; see Appendix 1) consists of three members. The lower one is the newly established Piekielnica Coral Limestone Member. It includes: (1) the discussed above grainstones, limestones with corals and micritic limestones with marly intercalations of the "basal unit" (this is conditionally attributed to the member herein, but possibly should be treated as a separate formal rock unit in the future), and (2) the overlying chalky limestones with commonly occurring hermatypic corals, corresponding to the upper part of the "chalky limestone member" of Kutek (1968). The middle part of the Bukowa Formation is the newly established Leśnica Limestone Member, including various limestones described by Kutek (1968; see also Pszczółkowski, 1970) as "the deposits overlying chalky limestones"; the upper member of the formation is composed mostly of marls and marly limestones of the "lowermost marly horizon" as distinguished by Kutek (1968) in the south-western margin of the Holy Cross Mts., being strictly comparable with the Góry Marl Member ("middle marly unit") recognized in the Wielun Upland (Wierzbowski, 2017a).

The bulk of the Piekielnica Coral Limestone Member (see Fig. 4 and Appendix 1) consists of bedded chalky limestones containing an abundant and diversified benthic shallow-water fauna including hermatypic corals - mostly found sparsely placed in beds, but forming also flat biostromes of the patch-reef type (Roniewicz, 1966; Roniewicz, Roniewicz, 1971), solenoporoids, bivalves (diceratids and various oysters), gastropods (nerineids), and others. The total thickness of the Piekielnica Coral Limestone Member (together with micritic limestones and grainstones of the "basal unit" treated as the lowermost part of the member) attains about 35 meters at Bukowa quarry (Matyja, 2011). Ammonites have been found here very rarely. A single giant specimen referred to as "Ringsteadia (Ringsteadia) sp." by Kutek (1968, pl. 14) from the upper part of this member is a strongly ornamented Vielunia very close to $V$. tenuiplexa (Quenstedt). This species is known from the lower part of the Platynota Zone (Geyer, 1961; Wierzbowski, 1970, 2017a).

The Leśnica Limestone Member as defined herein (Fig. 4; see Appendix 1) consists of micritic limestones and organodetrital-oolitic limestones containing bioclasts, intraclasts and ooids in various amounts, and some benthic fauna (Roniewicz, 1967; Kutek, 1968; Pszczółkowski, 1970). This member is well exposed in Bukowa quarry (Matyja, 2011), where it consists (from the bottom) of thick-bedded micritic limestones (about $6 \mathrm{~m}$ in thickness), which are overlain by thin-bedded limestones with marly intercalations (about $4 \mathrm{~m}$ in thickness), being successively covered by oolitic limestones (a few meters thick) locally showing cross-bedding and ripple-marks; these are overlain by thin-bedded micritic limestones with marly intercalations already belonging to the Góry Marly Member ("lowermost marly horizon" of Kutek, 1968). According to Pszczółkowski (1970), a marked regional difference in the development of the deposits referred herein to the Leśnica Limestone Member is observed in the south-western margin of the Holy Cross Mts. In the southern part of the area, between Staniewice and Leśnica, the deposits are dominated by oolitic-organodetrital limestones, which are sandwiched by micritic limestones, whereas towards the north and north-west micritic limestones become more common (Pszczółkowski, 1970, figs 1, 3; Fig. 4, herein). In detail, the distribution of these main lithological types is even more complicated, being related to occurrence of the discontinuity surfaces, and the possible sedimentary and/or erosionally reduced thickness of the beds. Such situation occurs e.g. in the upper part of the Leśnica Limestone Member. The Gruszczyn, Bukowa and Kościółek sections are more complete and show the presence of organodetritaloolitic limestones below the discontinuity surface (see also Kutek, 1968, fig. 7: where unit L3, representing possibly the same organodetrital limestones as mentioned above from the Kościółek-Leśnica section, should be attributed rather to the Leśnica Limestone Member, i.e. "the deposits overlying chalky limestones", than to the "chalky limestone member" as indicated therein). On the other hand, in the nearby Krzyżowa Góra section these younger deposits are missing, and the older micritic limestones occur directly below the discussed discontinuity surface (see Kaźmierczak, Pszczół- 
kowski, 1968, fig. 6B). The presence of stratigraphical gaps in the succession (including that occurring at least in some areas at the top of the unit), together with facies changes, thus makes a detailed correlation between the particular sections of the member difficult.

Ammonites are found only in the lower and middle, somewhat marly parts of the Leśnica Limestone Member. From Bukowa quarry (see Gutowski et al., 2006) came Orthosphinctes (Orthosphinctes) polygyratus (Reinecke) (Pl. 3: 1) and O. (Lithacosphinctes) gidoni Atrops (Pl. 2). Some additional fragmentary specimens were found in Głuchowiec quarry and studied by Kutek (1962a, 1968). These include fragments of a large specimen, which can be attributed to $O$. (Lithacosphinctes) sp. (as interpreted herein), and a fragment of Pictonia (Pomerania) originally referred to as "Pomerania schmidti (Dohm)" by Kutek (1962a, p. 379) - but later treated as specifically undeterminable (Kutek, 1968, p. 563). A well-preserved large specimen of Pictonia (Pomerania) dohmi (Arkell) described by Kutek (1968, p. 561-563, pl. 9; see also Pl. 4, herein) was found at the Krzyżowa Góra section (in subunit K4, see Kutek, 1968, fig. 7) - this specimen was originally referred also to Pomerania schmidti (Dohm) by Kutek (1962a, p. 379; 1962b). The whole assemblage of ammonites is undoubtedly indicative of the Platynota Zone (Kutek, 1968). Moreover, it should be remembered that the discussed ammonites of the genus Orthosphinctes do not occur above the lower part of the Platynota Zone (Atrops, 1982). The deposits of the lower-middle parts of the Leśnica Limestone Member should be thus correlated with the Polygyratus Subzone, representing the lower part of the Platynota Zone. The younger deposits of this member, as well as the overlying marly deposits of the Góry Marl Member ("lowermost marly horizon" of Kutek, 1968; see also Fig. 4) of the uppermost part of the Bukowa Formation have not yielded any ammonites and their stratigraphical position is considered below in a wider stratigraphical and geographical context. These marly deposits up to about 10-15 meters in thickness are best developed between Krasocin and Brzegi, but towards the north and the south they successively disappear, and are replaced by micritic limestones (Kutek, 1968; Pszczółkowski, 1970).

The "lowermost marly horizon" has been commonly treated as an easily recognizable unit, having additionally a large correlation potential in the Kimmeridgian of the south-western margin of the Holy Cross Mts. It was originally correlated (see Kutek, 1968, p. 533, 534, 545, tab. 3) with the "middle marly unit" of Wierzbowski (1966, see also Kutek et al., 1977) in the Wielun Upland and placed in a higher part of the Platynota Zone. This opinion was subsequently modified by Kutek (1994, p. 183, although without closer discussion), who located both the "lowermost marly horizon" as well as the "middle marly unit", together with their marly equivalents in central Poland, "low in the Platynota Zone". Moreover, all these marly deposits considered as isochronous were recognized by him as representing an important stratigraphical marker horizon B in the Upper Jurassic succession. This enabled the distinguishing of the two stratigraphical intervals I and II in the Upper Jurassic COK succession of central Poland by Kutek (1994), with their boundary placed at horizon B, located near the Planula/Platynota zone boundary (which was treated at that time as the Oxfordian/Kimmeridgian boundary in the Submediterranean Province). Such an opinion on the stratigraphical position of the discussed marly deposits was recently followed by some Polish authors (Krajewski et al., 2016, 2017; Olchowy et al., 2019), who additionally correlated the top of this marly horizon with the third-order sequence boundary Kim.1 of Hardenbol et al. (1998). The sedimentological aspects of such a correlation will be criticized below in the chapter "History of sedimentation"; here only some comments on the stratigraphical premises of this interpretation are considered. The "lowermost marly horizon" in the south-western margin of the Holy Cross Mts. occurs undoubtedly in the Platynota Zone, and it is placed well above its lower part as shown by ammonite findings. Although no ammonites have been found within the horizon itself, those occurring in the deposits occurring directly above indicate some higher levels of the Platynota Zone (see below). The Góry Marl Member in the Wielun Upland (="middle marly unit") which was treated always as the stratigraphical equivalent of the "lowermost marly horizon" did not yield any ammonites either, but some coming from the directly underlying deposits have suggested also a rather high stratigraphical position in the Platynota Zone (Wierzbowski, 2017a). Thus, the top of the discussed marly unit - the Góry Marl Member as interpreted herein, cannot be placed at the sequence boundary of Kim.1 of Hardenbol et al. (1998), as corresponding approximately to the boundary between the Planula and Platynota ammonites zones (but see also comments below on the difficulties in the precise interpretation of this sequence boundary level), because it is evidently younger.

Another stratigraphical correlation which has to be considered is that between the Góry Marl Member ("lowermost marly horizon" = "middle marly unit") and the marly deposits from the "Łódź Depression", including the Bełchatów and Złoczew areas, proposed by Olchowy et al. (2019, p. 678) as " a key to stratigraphic correlation of Upper Jurassic deposits in central and southern Poland". The marly unit of the Kiełczygłów-Szczerców-Belchatów areas which has been correlated with the "lowermost marly horizon" by Olchowy et al. (2019), corresponds to the Kiełczygłów Marl Member, however, and thus it is younger as shown by ammonites indicative of the lowermost part of the Hypselocyclum Zone occurring directly below it (Wierzbowski, 2017a). 
This erroneous correlation resulted mostly from the acceptance by Olchowy et al. (2019, and in some earlier papers cited therein) of a similar age for the oolites overlying the "lowermost marly horizon" in the south-western margin of the Holy Cross Mts. (i.e. the Małogoszcz Oolite Fm. as distinguished herein), and the "oolitic" formation sensu Wierzbowski (2017a, units C, D in figs. 5, 6), overlying the Kiełczygłów Marl Member in the Kiełczygłów-Szczerców area. In fact, as shown by ammonite faunas, the oolites in south-western margin of the Holy Cross Mts. correspond mostly to the upper parts of the Platynota Zone and range up into the basal part of the Hypselocyclum Zone only (see below, herein), whereas those of the Kiełczygłów-Szczerców area correspond to the upper Hippolytense Subzone - lower Lothari Subzone boundary interval of the Hypselocyclum Zone (Wierzbowski, 2017a).

Malogoszcz Oolite Formation (oolites and micritic limestones): upper Platynota to lowermost Hypselocyclum zones. The "oolite formation" sensu Dembowska (1979), although originally defined in a very general way, corresponds but partly to this well-defined lithostratigraphical unit in the south-western margin of the Holy Cross Mts. composed of oolites and associated organodetrital and micritic limestones ( $c f$. Matyja, 2011). The formation formally recognized herein (see Appendix 1) is the Małogoszcz Oolite Formation, and includes four newly established members, corresponding to informal lithostratigraphical units commonly recognized before, which names are given below in brackets (see Kutek, 1968, and earlier papers cited therein; see also Fig. 4): (1) Rogalów Limestone Member ("underlying pelitic limestones"); (2) Głuchowiec Oolite Member ("lower oolite"); (3) Mieronice Banded Limestone Member ("banded limestone member"); (4) Sobków Oolite Member ("upper oolite"). At the top of the formation occurs a very characteristic "onkolite horizon" distinguished herein as the Celiny Onkolite Bed. These lithostratigraphic units may be traced over the whole discussed area of the south-western margin of the Holy Cross Mts., although they show some differences in facies development (Kutek, 1968, 1969; Pszczółkowski, 1970).

The Rogalów Limestone Member is developed as micritic limestones up to about 10-15 meters in thickness, partly replaced by oolites with intercalations of micritic limestones, but the member may locally attain a very small thickness (Kutek, 1968; Matyja, 2011). The Głuchowiec Oolite Member consists of cross-bedded oolites, which dominate in the central part of the study area, between Skorków, Małogoszcz and Mieronice, attaining from 10 to 20 meters in thickness, but in other areas these deposits are partly replaced by oolites lacking cross-bedding, or even by micritic limestones. The Mieronice Banded Limestone Member, up to about 20 meters in thickness, consists of bands of micritic and very fine-grained organodetrital-oolite limestones with a very poor macrofauna, and show the presence of cherts at some levels. Its lithology was studied in detail in the Mieronice section (Kutek, 1962a). The deposits of this unit are locally developed as micritic limestones without organodetrital material, but also as oolites. The latter situation is observed near Żerniki and Brzegi, where the member passes laterally into oolites corresponding to the Sobków Oolite Member, attaining even about 35 meters in thickness (Kutek, 1968, tab. 2; 1969, fig. 6). On the other hand, the intercalations of oolites within micritic limestones, attributed to the Mieronice Banded Limestone Member at Bolmin (Pszczółkowski, 1970), suggest the complete lateral replacing of this unit by oolites. The Sobków Oolite Member, about 20-30 m in thickness, is mostly composed of oolites rich in micritic matrix and not showing any distinct bedding. Cross-bedded oolites occur mostly in a lower part of the unit, between Sobków in the south and Krasocin to the north, but some cross-bedded layers are recognized in its upper part as well (Kutek, 1968, p. 509 , tab. 2 , fig. 6 ; 1969 , p. 252 , fig. 6). Micritic limestone beds are recognized in some sections (Sokołów, Bolmin, Krzyżowa Góra near Małogoszcz) in the upper part of the Sobków Oolite Member (Pszczółkowski, 1970). The Celiny Onkolite Bed occurs at the top of the Małogoszcz Oolite Formation. It consists of a few layers of onkolite limestones, from several tens of centimeters to about 3 meters in thickness (Kutek, Radwański, 1965, 1967; Kutek, 1968). The onkolite layers can be recognized over a large distance in south-western margin of the Holy Cross Mts. Two main bodies of onkolite limestones can be recognized: one stretching from Rogalów to Brzegi in the northern and central part of the studied area, and another one placed a few meters higher in the succession, and occurring in its southern part, from Brzegi to Gołuchów and Celiny (Kutek, 1968, tab. 2; see also Fig. 4).

Ammonite findings are not common in the older deposits of the Małogoszcz Oolite Formation, in the Rogalów Member and the Gluchowiec Oolite Member, but they are fairly common in the upper part of the formation - in the Sobków Oolite Member, and especially in the Celiny Onkolite Bed. No ammonites have been ever found in the Mieronice Banded Limestone Member. The formation thus shows scattered ammonite findings in a few localities, mostly in its lower part, and this, in relation to the marked facies changes present, means that special caution is needed in chronostratigraphical correlation of the deposits. Of some help are the recognized discontinuity surfaces, a few of them having a larger regional continuity and representing horizons of the correlative value (see Kaźmierczak, Pszczółkowski, 1968).

The oldest ammonite assemblage of the Małogoszcz Oolite Formation comes from the micritic, partly grained (mostly oolitic) limestones of the Rogalów Limestone Mem- 
ber cropping out at Rogalów. They are possibly the lateral equivalent of the older deposits of the Gluchowiec Oolite Member ( $c f$. Kutek, 1968, tab. 2), and are directly underlain by the marly deposits of the Góry Marl Member (as discussed above). Three ammonite species of marked stratigraphical value are recognized and commented on as follow:

1. Orthosphinctes (Lithacosphinctes) aff. stromeri (Wegele) described originally as "Lithacoceras (Lithacoceras) evolutum (Quenstedt)" =O. (L.) evolutus (Quenstedt) by Kutek (1968, p. 550-551, pl. 3; see also Pl. 1, herein); see Appendix 2; it should be mentioned that $O$. stromeri occurs in the uppermost part of the Platynota Zone (in the Guilherandense Subzone), and is younger than O. evolutus known only from the lower part of this zone (Polygyratus Subzone) (see Atrops, 1982); the discussed form $O$. aff. stromeri is possibly somewhat older than $O$. stromeri, showing also some features of the older $O$. evolutus; thus, its occurrence inbetween the middle part of the Platynota Zone (Desmoides Subzone) and its upper part seems highly probable;

2. Rasenia inconstans Spath, originally described by Kutek (1968, p. 555, p. 11; see also Pl. 6, herein) as "Rasenia (Eurasenia) pendula Schneid", is a rather surprising discovery, because this ammonite does not belong to the Submediterranean genus/subgenus Eurasenia, showing a coiling and ornamentation very close to the earliest representative of Subboreal Rasenia as treated by Birkelund and Callomon (1985; $c f$. also Spath, 1935; see also Appendix 2, herein); the occurrence of this ammonite (which is indicative of the basal part of the Subboreal Cymodoce Zone) in the Submediterranean succession of central Poland has important palaeogeographical implications, but independently suggests correlation with some higher (middle-upper) parts of the Submediterranean Platynota Zone as usually shown in correlation charts (cf. Comment et al., 2015; Wierzbowski, Smelror, 2020);

3. Pictonia (Pomerania) cf. dohmi (Arkell) as indicated by Kutek (1968, pp. 511, 563, where this specimen was referred to as "Pomerania (Pomerania) cf. dohmi"; see Pl. 5: 1, herein); this species is known from the assemblage of Pomerania ammonites (originally referred to Pictonia by Dohm, 1925) from the Czarnogłowy = Zarnglaff quarry in western Pomerania (see Appendix 2), and when co-occurring with Rasenia it suggests a stratigraphical position near the boundary between the Subboreal Baylei and Cymodoce zones, i.e. near the middle-upper parts of the Platynota Zone, as discussed above.

The Głuchowiec Oolite Member has yielded a few ammonites, all of them found at Sobków quarry. These are large specimens of Pictonia (Pomerania) albinea (Oppel) [see Kutek, 1968, p. 514, 564, 565, pl. 8: 3, described as
Pomerania (Pachypictonia) albinea (Oppel)], and Pictonia (Pomerania) cf. dohmi (Arkell). These forms are still in part like Pictonia in their inner whorls, but resemble Rasenia on the outer whorls, being thus to some degree transitional between the two genera, although in a different evolutionary development, that of Pomerania-Pachypictonia (see Appendix 2, cf. also Birkelund, Callomon, 1985, p. 41; Wierzbowski, 2017b). Their occurrence is thus consistent with the stratigraphical interpretation of the ammonites from the Rogalów Limestone Member as discussed above.

A younger part of the Małogoszcz Oolite Formation corresponding to the Sobków Oolite Member has yielded a fairly rich and diversified assemblage of ammonites, mostly coming from Sobków quarry. Stratigraphically, the most important ones are representatives of the family Ataxioceratidae. The oldest of them is a large specimen of Orthosphinctes (Lithacosphinctes) pseudoachilles (Wegele), described by Kutek (1968, p. 509, 550, pl. 2) as "Lithacoceras (Lithacoceras) subachilles (Wegele)" (see Appendix 2). This species occurs in the middle part of the Platynota Zone, ranging upwards into the basal part of the topmost subzone (Guilherandense Subzone) of the zone. Although its detailed position in the Sobków Oolite Member was not indicated by Kutek (1968), who only mentioned that the bulk of specimens from Sobków quarry came from the upper part of the unit, this is the unique candidate to be ascribed to its lower part. Moreover, this part of the Sobków Oolite Member may be treated as the lateral facies equivalent of some upper parts of the Mieronice Banded Limestone Member. The rest of specimens of the family Ataxioceratidae indicate a somewhat higher stratigraphical position.

The occurrence of Ataxioceras (Parataxioceras) homalinum Schneid [ $=A$. ex. gr. discobolum (Font) in Kutek, 1968, p. 509, 553, pl. 4: 4], A. (P.) cf. hippolytense Atrops (Pl. 3: 4), and especially Ataxioceras (Schneidia) genuinum Schneid $[=$ Ataxioceras guentheri (Oppel) in Kutek, 1968, p. 509, 552, pl. 5: 1], and A. (Schneidia) sp. (=Ataxioceras involutum Geyer, in Kutek, 1968, p. 509, 552, pl. 5: 4a, b), all of them found at Sobków quarry, can be treated as indicative of the basal part of the Hypselocyclum Zone - corresponding mostly to the lussasense horizon of the lowermost part of the Hippolytense Subzone. The same stratigraphical position is indicated by Ataxioceras (Schneidia) lussasense Atrops (P1. 3: 2) found in the Sobków Oolite Member in the Małogoszcz cement-works quarry (see Atrops, 1982, also Wierzbowski, 2017a). Also the occurrence of "Ataxioceras ex gr. guentheri (Oppel)" in the younger part of the Małogoszcz Oolite Fm ("upper oolite") at Chmielnik, in the southernmost part of the south-western margin of the Holy Cross Mts. (Kutek, 1968, p. 528), which is possibly a representative of the subgenus Schneidia (see above), confirms such a stratigraphical interpretation of these deposits. 
The family Aulacostephanidae is represented in the Sobków Oolite Member by numerous specimens markedly dominating in number over Ataxioceratidae (after Kutek, 1968, p. 509, the proportion of ammonites of the two families is 14:5 in his collection from Sobków quarry). The most common ones are heavily ornamented raseniids represented both by very large specimens, which can be easily compared with Pachypictonia as interpreted herein (see Appendix 2), including such forms as Pachypictonia cf. peltata (Schneid) (see Kutek, 1968, p. 564, pl. 10) and P. cf. perornatula (Schneid) (Pl. 5: 2), and smaller specimens the interpretation of which needs some comments. The latter are mostly fragments of whorls or incomplete specimens with strong ribbing similar to that of Rasenia trifurcata (Reinecke) (Pl. 7: 1) - which is sometimes placed in the genus/subgenus Eurasenia (see Geyer, 1961), but whose relation to large Pachypictonia seems highly probable, especially when compared with larger specimens, showing a similar type of ornamentation (Pl. 7: 2). The stratigraphical value of these ammonites is not known in detail, because "the principal source of uncertainity is the lack of precise stratigraphy for almost all of the type specimens" of the German Pachypictonia (Birkelund, Callomon, 1985, p. 41). Nevertheless, the bulk of them is generally attributed to the Submediterranean Hypselocyclum Zone - mostly its lower and middle parts (e.g., Gygi, 2003), although some forms may appear possibly in the upper part of the Platynota Zone. Similarity in the evolutionary development between the Subboreal Rasenia lineage and the discussed Pachypictonia lineage (see Appendix 2) finds its spectacular confirmation in the occurrence of ammonites very close to Pachypictonia together with Rasenia inconstans in the lowermost part of the Cymodoce Zone in East Greenland (Birkelund, Callomon, 1985, p. 40-42, pls. 14: 5, $6 ; 15: 1 ; 16: 1)$. On the other hand, Rasenia balteata Schneid, which is very similar to $R$. trifurcata (see Gygi, 2003), has been discovered together with Pachypictonia in the lussasense horizon of the lowermost part of the Hypselocyclum Zone in the Radomsko elevation of central Poland (Wierzbowski, Głowniak, 2018). These data give the basis for a close correlation between the Subboreal and Submediterranean zonal schemes as based on material coming from central Poland, and additionally show the common occurrence of ammonites of Subboreal affinitity in the stratigraphical interval from upper part of the Platynota Zone to the lowermost part of the Hypselocyclum Zone.

Another group of Aulacostephanidae is represented by genera/subgenera of Submediterranean affinity. Here belong mostly species of Involuticeras such as I. limbatum (Schneid) (Pl. 9) and I. involutum (Quenstedt) (Pl. 8: 1) found in the upper part of the Sobków Oolite Member at Sobków quarry, and in the Leśnica (Kościółek hill) section (collected by Kutek, and from the author's collection). These ammonites are known from the Hypselocyclum Zone (see e.g., Geyer, 1961; Gygi, 2003). Also, a few specimens of Aspidoceratidae from the same unit were recorded, but not illustrated by Kutek [p. 509, 566 - placed in the genus Aspidoceras, and being close to Aspidoceras binodum (Oppel)] from Sobków quarry, and an additional specimen from the topmost part of the member from Celiny quarry. The discussed ammonites belonging to the Aulacostephanidae and Aspidoceratidae from the Sobków Oolite Member correspond to the Hypselocyclum Zone and have a smaller stratigraphical value than the above discussed Ataxioceratidae.

The discussed Aulacostephanidae of Submediterranean affinity become very common in the topmost part of the Małogoszcz Oolite Formation - in the Celiny Onkolite Bed. Here they constitute the bulk of the collected specimens (14 of 15 collected), being represented by Eurasenia such as E. vernacula (Schneid) (see Kutek, 1968, p. 556, pl.6: 1) and E. rolandi (Oppel) (see Kutek, 1968, p. 554, 555, pl. $6: 2$ ), Prorasenia quenstedti (Schindewolf) (see Kutek, 1968, p. 557, pl. 6: 4), and common Involuticeras - such as I. involutum (Quenstedt) (Kutek, 1968, p. 556, pl. 8: 1) and I. limbatum (Schneid) (Pl. 8: 2). These specimens were found in numerous outcrops by Kutek (1968, p. 509) and by the author: at Staniewice, Brzegi, Małogoszcz (including a large cement-works quarry), Leśnica (Kościółek hill), between Łopuszno and Krasocin, at Wola Świdzińska and Ostrów. All of them indicate the presence of the Hypselocyclum Zone. A single ataxioceratid ammonite coming from the Kościółek hill section (Kutek, 1968, p. 509) is Ataxioceras (Parataxioceras) (Pl. 3: 3a, b) which, although specifically difficult for determination, suggests the presence of the lower part of this zone.

The two discontinuity surfaces - one at the top of the Mieronice Banded Limestone Member (i.e. base of the Sobków Oolite Member) and another one at the top of the Sobków Oolite Member (i.e. base of the Celiny Onkolite Bed) were treated as having especially wide geographical distribution in the south-western margin of the Holy Cross Mts. (Kaźmierczak. Pszczółkowski, 1968; see also Fig. 4): the first one is traced over a distance of $28 \mathrm{~km}$, the second one over $57 \mathrm{~km}$ (and even $70 \mathrm{~km}$ as recorded by Kutek, Radwański, 1965); thus, they both can be treated as good stratigraphical markers. The possible nature of these sedimentary discontinuities will be discussed in detail in another part of this study. It may be mentioned only that in the case of the younger surface, the deposits underlying as well as those directly overlying the surface, show some features of stratigraphical condensation. This results in the fairly common occurrence of ammonite shells in the deposits directly adjoining the discontinuity surface in the upper part of the Sobków Oolite Member and in the Celiny Onkolite Bed, as discussed above. The ammonite assemblages can be subdi- 
vided into two different faunas. The older one, occurring in the upper part of the Sobków Oolite Member, is rather of an open marine character, being fairly diversified and composed of Aulacostephanidae (both of Subboreal and Submediterranean affinity), Ataxioceratidae and Aspidoceratidae. It is replaced in in the Celiny Onkolite Bed, at the top of the formation, by a fauna more restricted in its character, composed mostly of Aulacostephanidae of Submediterranean affinity - such as Eurasenia and Involuticeras, with the virtual absence of Pachypictonia - Rasenia, and very rare Ataxioceratidae. The overlying marly deposits of the Spinkowa Góra Formation (see below) are completely devoid of ammonites. All these records indicate that the development of the discussed discontinuity surface at the top of the Sobków Oolite Member was related to a decline of the sedimentation rate of the carbonates - before the subsequent input of detrital material drawn either by climatic or tectonic changes. It has been interpreted also as an effect of the drowning of the shallow-water carbonate platform deposits in the south-western margin of the Holy Cross Mts. (Matyja et al., 2006a). Features resulting from the slowing of the sedimentation rate of the carbonates were recognized also at the same stratigraphical level - i.e. in the lowermost part of the Hypselocyclum Zone (mostly the lussasense ammonite horizon) - in somewhat deeper marine deposits in other more distant areas, such as the Wielun Upland (Wierzbowski, 2017a) and the Radomsko elevation (Wierzbowski, Głowniak, 2018) of central Poland, which confirms that the reasons for the development of the discussed discontinuity surface and the resulting stratigraphical correlations were region-wide.

Spinkowa Góra Formation (micritic limestones and marls with intercalations of grained limestones): Hypselocyclum Zone. This newly established formation (see Appendix 1; see also Fig. 4) can be subdivided into four easily recognizable parts as seen in the large cement-works quarry at Małogoszcz (Matyja et al., 2006a, fig. B.2.30). A lowermost part is composed of marls with thin intercalations of micritic limestones, attaining about $5 \mathrm{~m}$ in thickness. It corresponds strictly to the Kiełczygłów Marl Member as recognized in the Wielun Upland and in the Radomsko elevation (see Wierzbowski, 2017a; Wierzbowski, Głowniak, 2018). A middle part, distinguished herein (see Appendix 1) as the Grabki Limestone Member, is composed of micritic limestones with layers of grained limestones (mostly of ooids, bioclasts and oncoids) with rare intercalations of oyster lumachelles. It attains about $12 \mathrm{~m}$ in thickness (Matyja et al., 2006a; Matyja, 2011). Both these lithostratigraphic units correspond to the "oolite-platy member", which is overlain in the northern and central part of the south-western margin of the Holy Cross Mts. by "the shaly limestones and underlying shales" as recognized by Kutek (1968, tab. 2).
These youngest deposits of the Spinkowa Góra Formation continue towards the north already outside the study area, at Dobromierz and Przedbórz (Kutek, 1968, tab. 2, fig. 11), and are distinguished herein as the Dobromierz Marl Member below, and the Buczyna Limestone Member above (see Appendix 1). These lithostratigraphic units are well-developed in the section of the cement-works quarry at Małogoszcz: the Dobromierz Marl Member consists here of marls (attaining about $12 \mathrm{~m}$ in thickness), whereas the overlying Buczyna Limestone Member consists of micritic "sublithographic" limestones (about $10 \mathrm{~m}$ in thickness), with an extremely rare and specific fauna, including the isopod Cyclosphaeroma and fragments of plesiosaur/pliosaur (Radwański, 1995; Matyja et al., 2006a). A discontinuity surface having a wide geographical distribution is developed at the top of the Buczyna Limestone Member in the whole south-western margin of the Holy Cross Mts. (see Kaźmierczak, Pszczółkowski, 1968; see also Fig. 4, herein).

The Kiełczygłów Marl Member showing a similar development to that described in Malogoszcz quarry is seen in nearly the whole south-western margin of the Holy Cross Mts., from Oleszno to Sobków, but towards the south at Staniewice, this unit disappears (cf. Pszczółkowski, 1970; see also Fig. 4, herein). The Grabki Limestone Member is recognized in its typical development in the middle part of the south-western margin of the Holy Cross Mts. from Lipie, Gruszczyn and Skorków, where it is composed mostly of micritic limestones, but with intercalations of fine-grained limestones, appearing near Leśnica and Małogoszcz. The deposits corresponding to the Grabki Member in the north show still another development between Oleszno and Rogalów, where oolitic limestones commonly appear (see Kutek, 1968; Pszczółkowski, 1970). This suggests an interfingering with another lithostratigraphic unit, mostly composed of oolites and formally not yet distinguished, occurring at the north-western border of the Holy Cross Mts. A markedly different development of the deposits corresponding at least partly to the Spinkowa Góra Formation is seen in the southernmost part of the south-western margin of the Holy Cross Mts. Here, beginning from the Bizorenda and Brzegi area towards the south, all the deposits of this formation were attributed by Kutek $(1968$, tab. 2$)$ to his "oolite-platy member" without any possibility of recognition of both marly deposits and the overlying "sublithographic" limestones (the Dobromierz Marl Mbr., and the Buczyna Limestone Mbr., as treated herein, respectively). On the other hand, large oolite bodies occurring within micritic limestones may attain here from a few up to about 10-20 meters in thickness, as it is the case in the Korytnica, Karsy and Gołuchów sections (Kutek, 1968; Pszczółkowski, 1970). Possibly a part of these oolites is the age equivalent of a younger Skorków lumachelle/"coquina" formation (see 
Pszczółkowski, 1970, cf. also Kutek, 1968, tab. 2; Kutek, 1994), and thus it is already younger than the deposits of the Spinkowa Góra Formation in the central and northern parts of the south-western margin of the Holy Cross Mts. It is an open question, whether all these deposits in the southernmost part of the south-western margin of the Holy Cross Mts. should be placed within the Grabki Limestone Member or distinguished as a separate member (or even formation) in the future (see Fig. 4).

No ammonites have ever been found in the Spinkowa Góra Formation. Taking into account the occurrence of ammonites indicative of the lowermost Hypselocyclum Zone directly below in the Celiny Onkolite Bed, as well as the ammonites of the topmost part of the Hypselocyclum Zone and the lowermost Divisum Zone directly above, in the basal deposits of the Skorków lumachelle/"coquina" formation (Kutek, 1968, 1994; Matyja, Wierzbowski, 2000; see also below), the deposits of the Spinkowa Góra Formation should be attributed to the Hypselocyclum Zone, including some parts of the Hippolytense Subzone as well as of the Lothari Subzone. The youngest deposits in the southern part of the area of study, attributed to the Spinkowa Góra Formation with reservation (see above), could possibly range up near the boundary of the Hypselocyclum and Divisum zones.

\section{HISTORY OF SEDIMENTATION}

General setting and modes of interpretation. During the Late Jurassic the large area of epicratonic Poland including the Holy Cross Mts. constituted a part of the northern Tethyan shelf covered from the Oxfordian up to the beginning of the Late Tithonian by epicontinental seas. Initially, in central and southern Poland the deep neritic sponge megafacies dominated, being replaced from the Middle Oxfordian to Early Kimmeridgian by shallow-water carbonate platform deposits. Such is the shallowing upward carbonate succession composed of the preceding sponge-megafacies deposits and the succeeding shallow-water deposits in the Lublin Holy Cross Mountains Carbonate Platform of south-eastern Poland. This carbonate platform developed on the eastern promontory of the Ukrainian Shield already during the Middle Oxfordian and reached the north-eastern margin of the Holy Cross Mts. area in the beginning of the Late Oxfordian, and the south-western margin during the Planula Chron of the Early Kimmeridgian (e.g. Matyja et al., 1989; Matyja, Wierzbowski, 1996, 2006a, 2014; see also Kutek, 1994; Gutowski, 1992, 1998, 2006).

During the Oxfordian and Kimmeridgian, the whole area of the Holy Cross Mts. remained a place of accumulation of thick, mostly carbonate, deposits. Their preservation today, as already indicated, resulted mostly from the NW-SE-ori- ented Laramian elevation and the following erosion, which removed the deposits from the present Palaeozoic core of the mountains, except their so-called "Mesozoic margins" (Kutek, 1968; see also Fig. 5, herein). This makes recognition of their original facies pattern difficult, and special caution is needed when discussing their palaeogeographical distribution and sedimentological setting. Crucial in that matter is the detailed chronostratigraphical interpretation of the deposits which enables the construction of time-controlled "separate levels" showing the distribution of particular facies assemblages with their environmental interpretations given. The stratigraphical position of sequences of strata can be based on fossils important for age-correlation, especially ammonites (which occur, however, only at some levels), but it can be also based on orbitally-controlled sedimentary cyclicity (Fig. 6). Such as an attempt to recognize climatic cycles of longer duration (of 100-kyr and 405-kyr) can be proposed when comparing the lithological character of the deposits studied and their chronobiostratigraphically established position with the detailed cyclostratigraphic correlation chart based on detailed geochemical analysis of the Early Kimmeridgian pelagic deposits of south-eastern France, having a good ammonite stratigraphy (Boulila et al., 2008, 2010; cf. Atrops, 1982). Some additional help comes also from a similar attempt of correlation presented recently for the Early Kimmeridgian succession of the Wielun Upland in central Poland, stratigraphically well-documented by ammonites (Wierzbowski, 2017a). Such an approach enables the presentation of suggested changes of sea-level in the studied succession.

On the other hand, the sedimentation of the Kimmeridgian deposits of the south-western margin of the Holy Cross Mts. was controlled also by synsedimentary tectonics (Figs. 5, 6). The character of the deposits as well as their thickness were strictly related to the activity of synsedimentary faults, as proved palaeontologically and shown by the marked contrast in coeval lithological development of deposits in neighboring areas of the north-western margin of the Holy Cross Mts., the Radomsko elevation, as well as the Wieluń Upland (see e.g. Barski, 2012; Matyja, Wierzbowski, 2014, 2016; Wierzbowski, 2017a; Wierzbowski, Głowniak, 2018). Such a distinct facies change in the area of the south-western margin of the Holy Cross Mts. was already noticed by Kutek (1969, p. 291). Excepting some local changes, he observed ones which had a "more general character" and resulted in the appearance at the end of the Early Kimmeridgian of more shallow-water deposits like oolites and lumachelles in southern (at Górki, Staniewice and Brzegi) and north-western (from Skorków to Oleszno) parts of the area of study (see Figs. 1, 2, 4, herein). In relation to the south-western margin of the Holy Cross Mts. special importance has been placed on the so-called Zawiercie-Busko Fault Zone, which brought the deposits typical of this area 

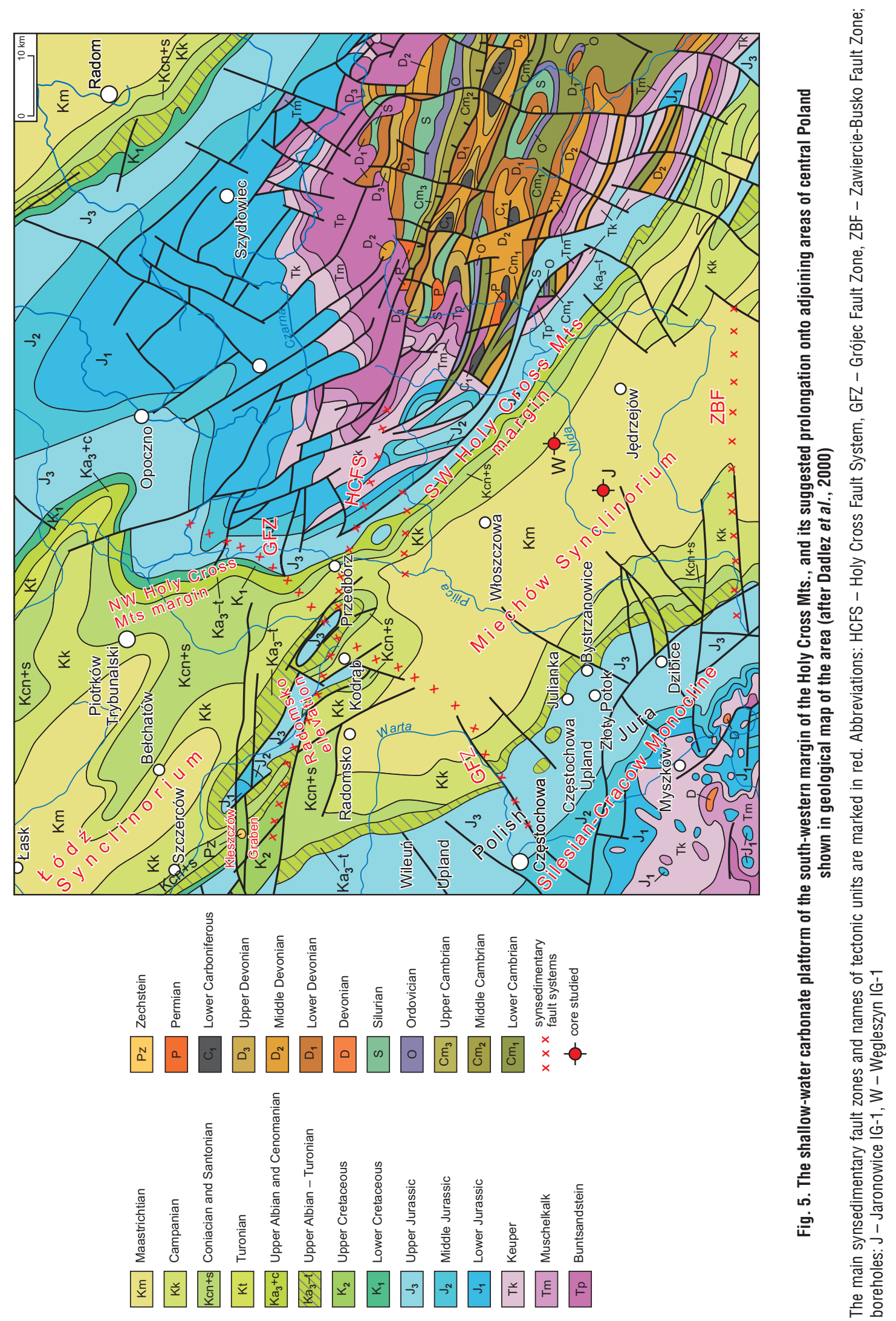


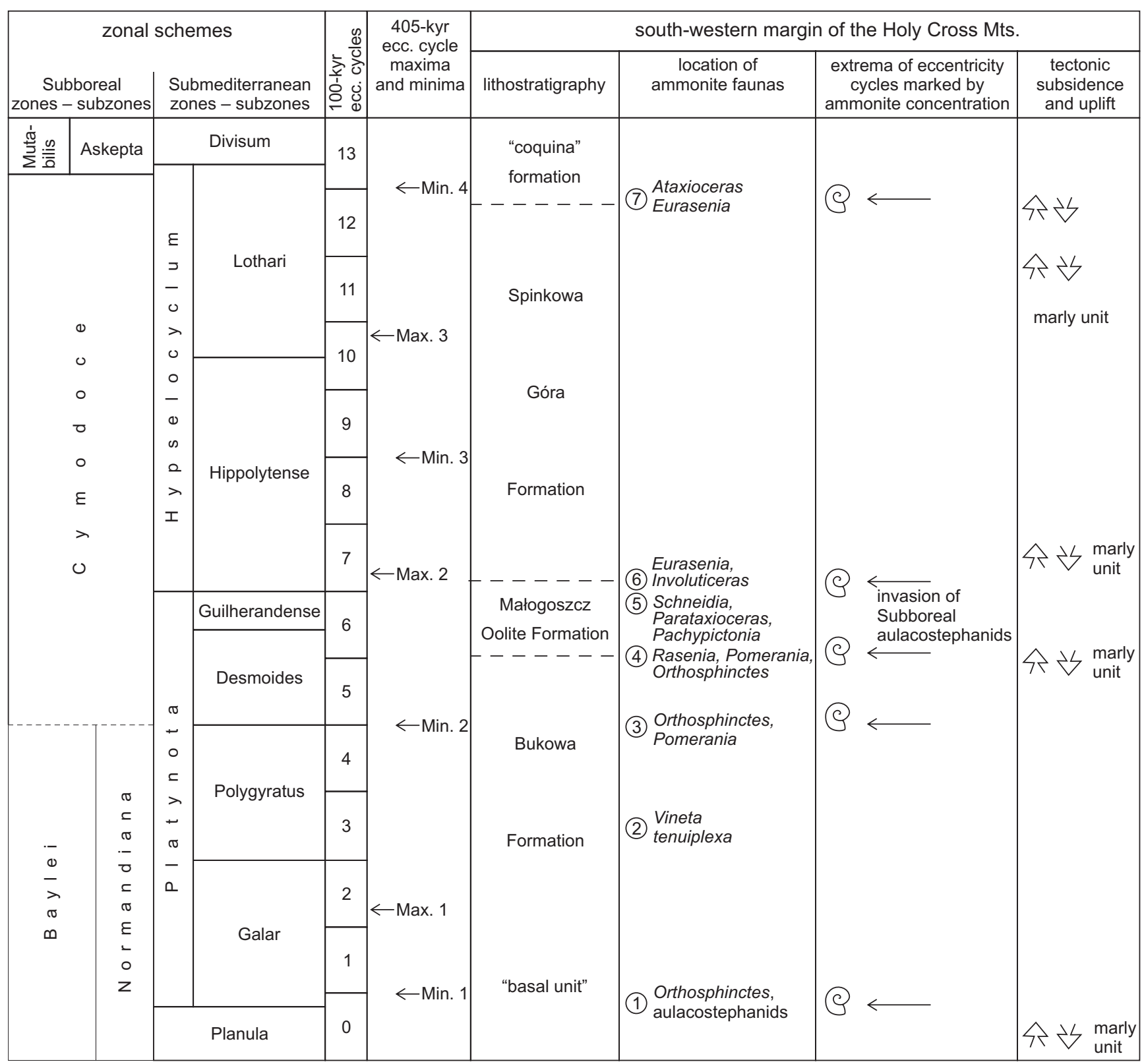

Fig. 6. Cyclostratigraphic scale based on 100-kyr and 405-kyr eccentricity cycles for the Lower Kimmeridgian uppermost Planula to upper Hypselocyclum zones (after Boulila et al., 2008, 2010) as compared with the ammonite zonations and lithostratigraphy of the shallow-water carbonate platform succession in the south-western margin of the Holy Cross Mts.

The levels with ammonites are indicated (cf. Fig. 4), and their correlation with extrema of the eccentricity cycles is shown. The suggested intervals of tectonic subsidence/uplift as based on the occurrence of contrasted facies are marked; these intervals are often associated with the appearance of thicker siliciclastic deposits denoted as marly units, recognized mostly as members in the lithostratigraphic scheme

into contact in the south with those of a completely different Late Jurassic facies zone (Różycki, 1953; Kutek, 1996; Matyja, 2009, 2015, and other papers cited therein). The northern border of the study area, as well as the neighboring part of the north-western margin of the Holy Cross Mts., stayed also under the influence of several faults showing synsedimentary activity, like the Holy Cross Fault System (lineament) (Matyja,Wierzbowski, 2014; Matyja, 2015), as well as its unnamed branch stretching directly along the northern border of the area of study from the southern segments of the 
Dobromierz Anticline and the Józefów Syncline, and possibly continuing east toward Żeleźnica, but also the Grójec Fault Zone (Figs. 2, 5). Their synsedimentary activity strongly influenced the general facies pattern - not only directly by the formation of elevated zones which became the place of formation of shallow-water oolites and other grained limestones, but also by development of the "quiet-water areas" in their neighborhood which were dominated by carbonate deposits formed in a lower-energy platform setting. The wider regional contex of the synsedimentary activity of these faults is discussed in the final chapter of this study.

The occurrence of fairly thick marly units placed in some intervals of the succession suggests the temporary inflow of silicilastic material, possibly from inner parts of the carbonate platform (Figs. 4, 6). Some of them were previously interpreted (Gutowski, 1992, 2006) in terms of sequence stratigraphy as deposits accumulated during the lowstand to transgressive system track. They can be, however, considered rather as caused by accommodation space changes related to tectonics which resulted from vertical movements on a regional scale. This is in accordance with the occurrence of the marly units in the close neighbourhood of the contrasted facies pattern which can be related with tectonic unconformities. The most plausible interpretation is that the deposition of the marly units resulted from the tectonic events, but that colder (and possibly more humid) climatic conditions leading to the enhanced hydrological cycle were at least partly superimposed, which enhanced the detrital input into the carbonate production.

Decline of sponge megafacies and incoming of the carbonate platform - Bimammatum to Planula chrons. The development of the deep-neritic, huge cyanobacteriasponge bioherm complexes took place during the Oxfordian up to the beginning of the Kimmeridgian (Bimammatum Zone). Their development has been recognized mostly in the northern and southern parts of the south-western margin of the Holy Cross Mts., whereas an interbiohermal basin filled with the bedded sponge-tuberolitic Morawica limestones occurred in between them, stretching general in the latitudinal direction from Żerniki, Siedlce and Sokołów in the west to Morawica and Wola Morawicka in the east (Matyja, 1977, figs. 1,4 ; 2015). As noticed above, a large original sea bottom relief between the top of the biohermal complexes and the bottom of the interbiohermal basin can reach even 150 200 m (Matyja, Wierzbowski, 1996; see also Matyja, 1977). The succeeding micritic limestones, representing the Siedlce Limestone Member of the Pilica Formation, attained their maximum development in the interbiohermal basin, thus offering the largest space for their accumulation, and reaching here up to about 535 meters in thickness (Matyja et al., 1989; Fig. 3). In the bulk of the member, up to the Bimammatum Zone, the deposits are micritic limestones of very high calcium carbonate content with extremely rare faunal elements. Their sedimentation rate was very high reaching up to about $28 \mathrm{~cm} / 1000$ year (Matyja, 2011). The deposits were laid down originally as muddy carbonate sediments of soupy-like character and represented an environment unsuitable for the development of a benthic fauna (Matyja et al., 1989). These deposits were possibly formed by the export of carbonate mud from the shallow-water carbonate platform located in the northern and north-western areas of the Holy Cross Mts. during the Late Oxfordian and the earliest Kimmeridgian (Matyja, Wierzbowski, 2014).

The uppermost part of the Siedlce Limestone Member, corresponding to the Planula Zone of the Lower Kimmeridgian shows the presence of lenses of the oolitic-onkoliticbioclastic grainstones, which represent the submarine fans of the prograding shallow-water carbonate platform (Matyja et al., 1989; Matyja, 2011). The topography of the sea-bottom was highly diversified, ranging from moderately deep basins where the micritic limestones were still being deposited, to elevated shoals, representing the tops of older cyanobacteria-sponge bioherms, settled by hermatypic corals (Matyja, 1977). The latter areas possibly became promontories of the progradating carbonate platform (possibly even stretching east-west according to the original directions of the bioherm complexes - Matyja, 2011, 2015), and places, where the detrital material for submarine fans came from.

A marked change in sedimentation took place in connection with the origin of the main discontinuity surface developed at the top of the Siedlce Limestone Mbr. (and the top of the Pilica Formation). The development of this surface, marking also the base of the Bukowa Formation, was related to strong winnowing of the micritic muddy sediment, and the appearance of favorable conditions for the existence of burrowing and then boring organism assemblages (Kaźmierczak, Pszczółkowski, 1968; Gruszczyński, 1986; see also Fig. 4). The deposits directly overlying the discontinuity surface in the south-western margin of the Holy Cross Mts. represent a highly diversified unit (called herein the "basal unit"), both in the character of the deposits but also in its thickness (Pszczółkowski, 1970). These are organodetrital limestones, oolitic limestones, but also micritic limestones and marly limestones and marls. Between the deposits of the unit and the underlying Siedlce Limestone Member is observed, at least locally, a small angular unconformity developed along the discussed discontinuity surface (Gutowski et al., 2006).

The regional data suggest the wide geographical distribution of the deposits in central Poland which can be correlated with those discussed above, corresponding to the phenomenon of the sudden progradation of the carbonate platform onto the whole area of the south-western margin of the Holy Cross Mts. (Matyja et al., 1989). In the northern 
part of the Polish Jura (Wielun Upland, and adjoining part of the Czestochowa Upland - placed westward from the area of study, and representing a distal foreland of the platform), this stratigraphical interval shows the replacement of the interbioherm thick marly unit (Latosówka Marl Member of the Pilica Formation) by the overlying chalky limestones with an abundant fauna of the Kuchary Limestone Member of the Prusicko Formation (see Wierzbowski, 2017a, fig. 2). This succession marks the transition from the diversified sea-bottom relief of the bioherm to basin topography to the fairly uniform and moderately shallow-water conditions, formed within rather a short time interval, corresponding to the end of the Planula Chron (placed before the beginning of the Galar Subchron), and marked often at the top by stratigraphic condensation (see Wierzbowski, 2017a). The local differences in thickness of the marly deposits of the Latosówka Marl Mbr. (and underlying micritic limestones) were strictly controlled by the activity of a synsedimentary fault (or set of faults), like that stretching along the Warta river valley and corresponding to the Grójec Fault Zone (Matyja, Wierzbowski, 2016, Wierzbowski, 2017a; see also Fig. 5, herein). Moreover, the unusual large thickness of the marly deposits of the Latosówka Marl Mbr., locally attaining 100 m (Matyja, Wierzbowski, 2016), as well as the common occurrence of detrital quartz grains suggest a rather sudden transport of huge masses of detrital material, and excludes their accumulation due to environmentally controlled inhibition of carbonate productivity.

All the data given strongly suggest that the depositional history at the end of the Planula Chron was controlled by tectonic synsedimentary activity (Fig. 6). The tectonic elevation of the areas of the Lublin-Holy Cross Mountains Carbonate Platform of south-eastern Poland resulted in tectonically accelerated shallowing of the basin, and the distribution of fine detrital material, coming possibly from the inner parts of the carbonate platform areas, where such deposits were formed ( $c f$. Niemczycka, 1976a, 1981). In a deeper part of the basin of central Poland, in the Polish Jura area, it resulted in the fast supply and deposition of the thick marly-silty deposits of the Latosówka Marl Member. In the newly formed areas of the shallow-water carbonate platform of the southwestern margin of the Holy Cross Mts., the shallowing resulted in the development of the discontinuity surface, and subsequently in the appearance of the local-origin grainstones, and other organogenic limestones formed on the existing elevations and representing the common deposits of the "basal unit". In some other more protected areas, the deposition of micritic limestones with intercalations of marly limestones and marls took place, such as those near Leśnica and Bukowa Góra, where the corresponding deposits were distinguished in the cores as the marly unit " $m A$ " by Bar-
wicz-Piskorz (1995); these were the only remnants of the fine siliciclastic detrital material corresponding to the Latosówka Marl Member, which was swept over the outer part of the carbonate platform. The end of the marly sedimentation of the Latosówka Marl Member is marked by the occurrence of the condensed deposits with ammonites of the latest Planula Chron in the northern part of the Polish Jura (Wierzbowski, 2017a), but the micritic limestones of the "basal unit" of Bukowa quarry in the study area also yielded some ammonites, possibly of similar age (see chapter on the facies succession herein). This suggests that the decline of sedimentation was marked by an episode of an elevated sealevel (see also below).

The stratigraphical succession of the Late Jurassic between the Holy Cross Mts. and the Polish Jura was interpreted in terms of sequence stratigraphy by Gutowski (2006, figs B.2.3, 2.4, and earlier papers cited therein). He considered the base of the sedimentary sequence at the marly horizon (Latosówka Marl Mbr. herein) to be indicative of the lowstand/transgressive system track in the upper part of the Planula Zone. However, the eustatic control of this level according to that which has been presented above cannot be accepted. The origin of the deposits discussed was mainly controlled by tectonic activity; they have no universal distribution, and thus, they should be considered in terms of a tectono-stratigraphic or tectono-eustatic unit only ( $c f$. also Kutek, 1994).

When discussing the "basal unit" of the Bukowa Formation, and its relation to the Latosówka Marl Member, it is worth noting that the decline of siliclastic sedimentation was possibly controlled by orbitally-forced climate changes. Such a suggestion results from the character of the youngest deposits of these units, as well as from the time-correlation with the cyclostratigraphically elaborated section Châteauneuf-d'Oze in south-eastern France (cf. Boulila et al., 2008, 2010). The youngest deposits studied correspond possibly to the uppermost part of the minutum=schroederi ammonite horizon at the top of the Planula Zone (treated as the base of the Galar Subzone of the Platynota Zone, see Wierzbowski, 2017a), whereas the same level as documented by ammonites in the pelagic succession of SE France corresponds to the minimum (Min.1) of the 405-kyr eccentricity cycle (and nearly coeval minimum of the 100 -kyr eccentricity cycle). This level marks the minimum of the magnetic susceptibility (MS), and corresponds to enhanced carbonate production, showing the maximum insolation, which appears to have induced a very high sea-level according to the model proposed by Boulila et al. $(2008,2010)$. This interpretation seems to be in full accordance with the end of the influx of detrital material in relation to a higher sea-level, which flooded the carbonate platform of the Holy Cross Mts. (cf. Fig. 6). 
The interpretation given is also a good opportunity to discuss problems of the boundaries of the "universal" eustatic sequences, taking as an example the Kim 1 third-order sequence as distinguished by Hardenbol et al. (1998) which has sometimes been correlated with the deposits in question, but sometimes also with the topmost level of the directly younger marly deposits (Góry Marl Member) of the studied succession (Krajewski et al., 2016, 2017; Olchowy et al., 2019). The main problem with this and other boundaries is their unprecise dating in terms of ammonite stratigraphy, and the diversified character of deposits in which they are distinguished. The base of the Kim.1 third-order sequence was placed within the Platynota Zone by Colombié and Strasser (2003, figs. 3, 4), in the upper part of the Orthosphinctes=Polygyratus Subzone (but note that the authors did not distinguish precisely the base of the zone). As was noticed by Boulila et al. (2008, figs. 2, 6) that sequence boundary as interpreted by Colombié and Strasser (2003) matches generally the 405-kyr MS minimum (in this case the Min.2), which, on the other hand (see Boulila et al., 2010, fig. 2), corresponds to the main-flooding surface deposits. The position of the Kim. 1 after Hardenbal et al. (1998) should be placed rather at the beginning of the lowstand deposits and thus nearly to the 405-kyr MS maximum (Max. 1) - in the lowermost part of the Platynota Zone, i.e. in the Galar Subzone, if included into the Platynota Zone (cf. Boulila et al., 2008, fig. 6).

Initial stage of development of the carbonate platform - early to middle Platynota Chron. The coral limestones, representing the bulk of the Piekielnica Coral Limestone Mbr. of the Bukowa Formation, are developed mostly in the chalky limestone facies (Fig. 4). This facies composed of friable, biogenic limestones shows "a certain monotony of sedimentation, and constancy of its conditions" and does not display "any evidence of the activity of currents in the form of cross-stratification or erosional surfaces" (Roniewicz, Roniewicz, 1971, p. 407, 408) which indicate a rather calm water environment. The organic assemblages beside the branching and massive corals are represented by shallow-water bivalve (Diceras-Trichites-Actinostreon) - gastropod (nerineids) - and calcareous algae (solenoporoids and Marinella) assemblages. Onkolites are common. The corals can form flat buildups of the patch-reef type attaining up to 4 meters in height, and about 20 meters in length (Roniewicz, Roniewicz, 1971; Roniewicz, 2004). The occurrence at some levels of dominant thick-walled bivalves and nerineids together with large onkolites, without corals, and with a common biodetrital matrix (cf. Roniewicz, 2004) indicates the temporary appearance of more turbulent conditions. The deposits as a whole were formed at the lower slope of the carbonate platform, in a relatively quiet deeper zone. However, the common occurrence of corals, which represent the pioneer community, marks the transition from deeper-neritic to shallow-water higher energy conditions (Matyja et al., 1989).

The top of the Piekielnica Coral Limestone Member reveals commonly the presence of the discontinuity surface (Kaźmierczak, Pszczółkowski, 1968; Pszczółkowski, 1970). The directly overlying deposits of the Leśnica Limestone Member show a strongly diversified facies pattern (Pszczółkowski, 1970; see also Fig. 4, herein). The predominance of organodetrital-oolitic limestones was stated to be initially in the southern part of the area of study from Staniewice to Leśnica. These deposits either wedge out or are laterally replaced by some parts of the micritic limestones, beginning from Ostrów, Bolmin and Małogoszcz towards the north, but successively micritic limestones spread over the organodetrital-oolitic limestones also towards the south (Pszczókowski, 1970, fig. 3). The recognized facies boundary between the organodetrital-oolitic limestones and micritic limestones in the lower part of the member runs approximately in an east-west (locally also NW-SE) direction, and seems to correspond to the older boundary between the Late Oxfordian-earliest Kimmeridgian cyanobacteria-sponge biohermal complex of the northern part of the study area and the adjacent interbiohermal basin to the south. A similar distribution of facies occurred during deposition of the "basal unit". Such persistency of the facies boundary suggests that it was tectonically controlled.

The fairly common occurrence of ammonites in the micritic limestones indicates open-marine conditions and can be interpreted as indicative of the transgressive episode. The ammonites were found in the lower-middle parts of the micritic limestones in the northern part of the study area $\mathrm{Bu}-$ kowa quarry, and Krzyżowa Góra quarry - see Kutek, 1968; Gutowski et al., 2006), but also in micritic limestones lying directly above the organodetrital-oolitic limestones towards the south (Mieronice quarry, cf. Kutek, 1962a; Pszczółkowski, 1970). All these ammonites are indicative of the lower part of the Platynota Zone (Polygyratus Subzone). When discussing their environmental and stratigraphical value two observations should be taken into account: (1) these ammonites are not younger than the uppermost part of the Polygyratus Subzone; (2) their fairly common occurrence suggests a moderate to slow sedimentation rate of the deposits.

The discussed stratigraphical interval with ammonites corresponds most likely to the uppermost part of the Polygyratus $=$ Orthosphinctes Subzone of the lower Platynota Zone, near the boundary with the overlying Desmoides Subzone of the middle Platynota Zone (Fig. 6). Stratigraphical condensation at this level marked by the common occurrence of ammonites is commonly recognized to the west in the neighboring areas of the northern part of the Polish Jura (Wielun Upland) at the top of the Kuchary Limestone Mem- 
ber of the Prusicko Formation (Wierzbowski, 2017a, and earlier papers cited therein). The boundary between the Polygyratus and Desmoides subzones is a very distinctive level in the cyclostratigraphic correlation chart of SE France (Boulila et al., 2008, fig. 2; Boulila et al., 2010, fig. 2). It corresponds to the minimum (Min.2) of the 405-kyr eccentricity cycle (and nearly coeval minimum of the 100-kyr eccentricity cycle). This level marks the minimum of the magnetic susceptibility (MS) and very high sea-level, according to the model proposed by Boulila et al. $(2008,2010)$, which is in accordance with the suggestions given above (see also Wierzbowski, 2017a, fig. 12).

Shallow-water carbonate sedimentation versus clay/ siliciclastic material input - middle Platynota Chron. The upper part of the Leśnica Limestone Mbr. in the Bukowa quarry section was studied in detail by Roniewicz (1967, fig. 1). He recognized at the top of the micritic limestones with marly intercalations (occurring directly above those which yielded the discussed ammonites of the lower part of the Platynota Zone) several lithological units of carbonates, showing generally a shallowing-upward trend. These were from the base: micritic limestones, showing at the top of the beds surfaces of sedimentary discontinuity with commonly occurring burrow traces, and the overlying oolite unit (about 5 meters thick) composed of oolites and organodetrital limestones, passing upwards into cross-bedded oolites, and covered by oolites with ripple-cross lamination. Surfaces with oscillation ripple-marks were commonly recognized in the oolite unit. The topmost part of this succession at Bukowa quarry (Matyja, 2011, fig. 3) was represented by thin-bedded micritic limestones with intercalation of marls of about 2 meters in thickness; these were overlain by a single layer of micritic limestones with cherts, showing a surface with mud-cracks. These deposits as well as the overlying marls represent already the Góry Marl Member of the topmost part of the Bukowa Formation.

The study of the neighboring Leśnica section showed the presence of the discontinuity surface at the base of the oolite unit, corresponding to that of Bukowa quarry in the uppermost part of the Leśnica Limestone Member (see Kaźmierczak, Pszczółkowski, 1968, fig. 6B, surface 1). On the other hand, the Krzyżowa Góra section, about $3 \mathrm{~km}$ south-east of the Leśnica section showed the total absence of the oolite unit above the discussed discontinuity surface, whereas the younger discontinuity surface (Kaźmierczak, Pszczółkowski, 1968 , fig. $6 \mathrm{~B}$, surface 2) was placed in a similar position to that in the Leśnica section at the base of the marly deposits of the Góry Marl Mbr. These observations suggest a longer persistence of the stratigraphical gap between the development of the two discontinuity surfaces at the Krzyżowa Góra section than in the Leśnica section (where the corresponding gap was partly filled up by sedimentation of the oolitic unit, about 5 meters in thickness); however, some erosion of the deposits at the Krzyżowa Góra section is also possible (Kaźmierczak, Pszczółkowski, 1968; Pszczółkowski, 1970). According to Kutek $(1968,1969)$ the differences in development of the youngest carbonate deposits of the Leśnica Limestone Member, from cross-bedded oolites to micritic limestones, could have resulted from local facies changes and the development of more quite-water and more turbulent-water conditions in the shallow-water carbonate platform areas. This evidence for the contrasted development of sedimentation in not very distant sections of the middle part of the south-western margin of the Holy Cross Mts. (Fig. 4) suggests that rather highly diversified conditions existed during the formation of the uppermost shallow-water carbonates of the Leśnica Limestone Member.

The deposits overlying the discussed shallow-water carbonates are the marls and marly limestones of the Góry Marl Member (="lowermost marly horizon" of Kutek, 1968). This unit, attaining up to about 10-15 meters in thickness, occurs in the south-western margin of the Holy Cross Mts. from Rogalów and Krasocin in north-west, and the environs of Brzegi (Kutek, 1968) and Sobków (Chudzikiewicz, Wieczorek, 1985) in south-east; it is known also from the area between Bolmin and the Bzowica-Leśna hills towards the north-east (Kutek, 1968). Its strongest development occurs, however, between Skorków and Żerniki, along a WNW-ESE stretching zone (Pszczółkowski, 1970). This latter area corresponds approximately to that which showed the presence of the organodetrital-oolitic limestones of the "basal unit" of the lower part of the Bukowa Formation (cf. Pszczółkowski, 1970, fig. 1), and which marked the position of an older interbiohermal basin during the Late Oxfordian and the earliest Kimmeridgian, as discussed above.

The Góry Marl Member successively disappears towards the NW, being replaced by the micritic and oolitic limestones at Oleszno (Kutek, 1968, tab. 2; 1969, p. 282), as well as towards SE near Staniewice, where it is replaced by the micritic limestones and fine-grained limestones (Kutek, 1968, tab. 2; Pszczółkowski, 1970; see also Fig. 4). Such a distribution of this unit indicates that the deposition of marls and marly limestones took place in an elongated depression, which was inherited possibly after an earlier stage of facies development (Kutek, 1969, p. 270). According to the data given, the deposition area of the Góry Marl Member was possibly tectonically-controlled, and its sedimentation was coeval with that of the limestones in the neighboring areas of the south-western margin of the Holy Cross Mts.

Crucial for the interpretation of the depositional environment of the marly deposits of the Góry Marl Member in the area of study is their palaeontological and sedimentological characteristics. The data, however, are rather limited. Alexandrowicz and Barwicz-Piskorz (1974), when studying the 
marly succession in the cores at Bukowa quarry, noticed the very impoverished foraminifer assemblage, and only the occasional occurrence of other microfossils (holothurian sclerites, ostracodes) in the bulk of the unit, whereas a more diversified microfaunal assemblage (numerous foraminifers, small gastropods) appeared only at the top of the marly deposits along with thin intercalations of organodetrital material. The bulk of the marly deposits does not show, however, any recognizable kinds of macrofauna, whereas the occurrence of spectacular finds of terrestrial flora (leaves) was recognized in the directly underlying carbonate deposits of the Leśnica Limestone Member at Krzyżowa Góra (Kutek, 1969, p. 276). As for sedimentological structures, mudcracks were discovered at the top of a bed, in the lowermost part of the Góry Marl Mbr. in Bukowa quarry (Matyja, 2011). Also commonly encountered are synsedimentary deformations interpreted as the effect of submarine slumping or the creeping of marly deposits on the inclined bottom (Radwański, 1960; Kutek, 1969); some of them, however, could be interpreted as early diagenetic deformations, such as load-casts, resulting from the original unstable density stratification of the sediment (Matyja, 2011). The mineralogical composition of the marly deposits was not studied in detail, although silt-sized quartz grains are stated to be fairly common (Kutek, 1969).

According to aforegoing, sedimentation of the marly deposits of the Góry Marl Member in the south-western margin of the Holy Cross Mts., took place (at least partly) in a non-fully marine environment of possibly lowered salinity, such as a shallow lagoon or a protected-bay area. Sedimentation of the marly (and partly also silty) deposits was controlled by climatic factors (but possibly it was superimposed on the tectonic activity, see also below). Sedimentation took place mostly in the elongated, about $20 \mathrm{~km}$ wide zone (when assumed its approximately latitudinal direction) bordered from north and south by carbonate shoals. The character of sedimentation of these carbonates is not fully recognized, however. In contrast to the older carbonates of the Leśnica Limestone Member which underly the marly deposits and commonly show the presence of the oolites; these younger carbonates coeval with the marly deposits seem to be richer in micritic limestones ( $c f$. Pszczółkowski, 1970). Also the deposits directly overlying the Góry Marl Member, corresponding already to the Rogalów Limestone Member ("underlying pelitic limestones" of Kutek, 1968), consist mostly of micritic limestones and marls with intercalations of bioclastic and oolitic limestones. Such is the lithology of deposits in Sobków quarry studied in detail by Chudzikiewicz and Wieczorek (1985, fig. 1), who treated them originally as representing the upper part of the "lowermost marly horizon" of Kutek (1968). These deposits were interpreted later (Krajewski et al., 2014, fig. 2; Krajewski et al., 2017, fig. 3) as belonging to the "underlying micritic limestones", i.e. the Rogalów Limestone Member of the lowermost part of the Małogoszcz Oolite Formation as recognized herein. Such an interpretation is based on the occurrence of a characteristic layer situated directly below, composed of bored and encrusted pebbles, treated as the result of reworking and the accumulation of clasts coming from the erosion of the hardground at the top of the marly deposits (Krajewski et al., 2014, 2017; see also Chudzikiewicz, Wieczorek, 1985). The corresponding deposits are also exposed in the Bukowa quarry section, where the hardground surface is developed on the finely laminated micritic limestone bed (more marly in its lower part) with commonly occurring fenestral structures (Matyja, 2011). The level, marked either by an accumulation of bored and encrusted clasts or by the non-eroded hardground surface, is treated as a regional hardground horizon developed at the top of the marly unit (Góry Marl Mbr.) in the south-western margin of the Holy Cross Mts. (Krajewski et al., 2014, 2017; see also Chudzikiewicz and Wieczorek, 1985).

The marly deposits of the Platynota Zone are widely distributed in the areas which represent the distant foreland of the discussed shallow-water carbonate platform. This is the case in the Wielun Upland, where two marly units lying in close proximity to each other, but sandwiched by a micritic limestone unit have been recognized: a few meters thick marly unit (Zapole Marl Bed) below, and a distinct marly unit above up to 30 meters thick (Góry Marl Member). These deposits were formed in a fully-marine environment as evidenced both by their macrofaunal and microfaunal (mostly foraminifer) content (Wierzbowski, 1966; Garbowska, 1970). The presence of these marly units was considered as having been controlled mostly by climatic conditions, but some additional tectonic activity during their formation could possibly be the case as well (Wierzbowski, 2017a). The Zapole Marl Bed was interpreted as a showing a fragment of a regressive trend (marked by the detrital siliciclastic input of the short eccentricity cycle after the Polygyratus Chron). The top of the overlying micritic limestones, showing some features of stratigraphic condensation, and occurring in between the two marly units, directly below the Góry Marl Mbr., was correlated (Wierzbowski, 2017a) with the top of the next short eccentricity cycle as recognized by Boulila et al. $(2008,2010)$ in the higher part of the Platynota Zone in their cyclostratigraphic correlation chart of SE France. The Góry Marl Member represents undoubtedly the interval of increased supply of siliclastic-marly deposits in the generally regressive succession, and correlates with a minimum of insolation and a lower sea-level period. However, its topmost part reveals the features of the next transgressive trend (see also below). Although the deposits directly overlying the Góry Marl Member in the Wielun Upland are 
poorly known, being studied only in boreholes, they were recently recognized in the succession of Rogaszyn quarry at the neighboring Radomsko elevation (Wierzbowski, Głowniak, 2018). The deposits occurring only locally are of condensed character and yielded fairly abundant ammonites indicative of a higher part of the Platynota Zone. This suggests the occurrence of another level, which may be correlated with a higher sea-level period, and the top of the short eccentricity cycle.

When interpreting the succession present in the southwestern margin of the Holy Cross Mts., the hardground surface/clast accumulation level as discussed above, seems to be of some importance. This level occurs at the top of the "lowermost marly horizon" = Góry Marl Member, and can be treated as evidence of a "temporarily lowered accumulation rate" (Chudzikiewicz, Wieczorek, 1985). This, together with the end of the siliciclastic/marly influx, and the appearance of ammonites in the directly overlying deposits of the Małogoszcz Oolite Formation, in the northern (in the Rogalów Limestone Member at Rogalów) and in the southern (in the Głuchowiec Oolite Member at Sobków) parts of the south-western margin of the Holy Cross Mts., suggests the flooding of very shallow and/or nearly emerged and/or lagoonal areas of the carbonate platform. These, as well as the observations given above related to the carbonate platform foreland, seem to indicate a generally rising sea-level during the late Platynota Chron. It is thus highly possible that this level (and not that at the base of the Góry Marl Member as suggested before, $c f$. Wierzbowski, 2017a, and discussion above) corresponds to top of the short eccentricity 100-kyr cycle. According to Boulila et al. (2008, fig. 2; 2010, fig. 2) this phenomenon, corresponding to the MS minimum of the 100-kyr eccentricity cycle, is observed in the upper part of the Desmoides Subzone, near the boundary of the overlying Guilherandense Subzone in SE France, as based on a detailed study of the ammonite succession ( $c f$. Atrops, 1982). If such a correlation with the succession of south-eastern France is accepted, the lowermost deposits of the Małogoszcz Oolite Formation, lying directly above the Góry Marl Member of the Bukowa Formation, should be correlated with fairly high levels of the Platynota Zone, near the boundary of the subzones as discussed above (Fig. 6). A strong argument in favour of such an interpretation, in addition to the sedimentological reasons, is that the stratigraphical interpretation of the ammonites coming from the discussed deposits of the south-western margin of the Holy Cross Mts., indicates "near middle-upper parts of the Platynota Zone", as commented on in the chapter on the facies succession and its stratigraphical interpretation herein.

The above discussed layer composed of the "bored and encrusted hiatus-concretions" or the re-deposited bored and encrusted clasts corresponding to the regional hardground at the top of the "lowermost marly horizon" (=Góry Marl Member as recognized herein), was the subject of sedimentological and stratigraphical interpretations by Krajewski et al. $(2014,2017)$, and additionally by Krajewski et al. (2016) and Olchowy et al. (2019). They correlated the layer cropping out at Sobków quarry in the south-western margin of the Holy Cross Mts. (described previously by Chudzikiewicz and Wieczorek, 1985), with other, similarly looking layers in the Lower Kimmeridgian from the cores in the Złoczew and Szczerców-Bełchatów areas, in the southwestern limb of the Łódź Synclinorium. According to them the "layer... (represents) an important marker horizon for correlation of the Upper Jurassic sediments in Poland" (Krajewski et al., 2014, p. 127), and their correlation was the basis for several general statements on its origin. However, as already indicated before (see description of the Bukowa Formation in the chapter on the facies succession herein), the age-correlations between the marly deposits underlying the layer in question from the south-western margin of the Holy Cross Mts. and the marly deposits underlying the similarlylooking layers from the south-western limb of the Łódź Synclinorium have been given wrongly, because these deposits are not isochronous. Thus, any wider regional implications related to the palaeogeographic position of the deposits in question and especially to the occurrence of synchronous massmovements on a larger scale which had attributed to their development (Krajewski et al., 2017), seem unsubstantiated.

Additionally, brief comments are made here concerning some sedimentological problems strictly related with the interpretation of the discussed Early Kimmeridgian hardground level from the south-western margin of the Holy Cross Mts. by Krajewski et al. (2014, 2017). The level was treated as "the regional hardground interpreted as the thirdorder sequence boundary Kim.1" which followed the development of the "lowermost marly horizon" "during the sealevel fall" (Krajewski et al., 2017). Such an opinion, however, differs markedly from that presented herein according to which the transition from marly deposits to the overlying limestones through the discussed hardground surface represents a transgressive and not a regressive succession. In such a case, the layer in question should not be interpreted as a third-order sequence boundary, but rather as a transgressive surface in terms of sequence stratigraphy. Moreover, if the origin of the layer with clasts with borings was initiated by the Early Kimmeridgian synsedimentary activity of the Holy Cross Fault (Krajewski et al., 2014, p. 127) and the subsequent re-deposition as a debris flow (Krajewski et al., 2017, fig. 9), its occurrence should rather not be referred directly to the "universal" scheme of Hardenbol et al.'s (1998) sequence boundaries. 
Oolitic limestone dominated interval - late Platynota Chron-earliest Hypselocyclum Chron. The Małogoszcz Oolite Formation as recognized herein includes two oolite lithostratigraphic units - the Gluchowiec Oolite Member ("lower oolite") 10-20 m in thickness, and the Sobków Oolite Member ("upper oolite") 20-35 meters in thickness, which are the most oolite-dominated units in the south-western margin of the Holy Cross Mts. They are separated by limestones composed of alternating bands of micritic and fine-grained material (Mieronice Banded Limestone Member = "banded limestone member"), and underlain by micritic limestones with intercalations of organodetrital and oolitic limestones (Rogalów Limestone Member). The top of the formation is marked by a thin, fairly uniform horizon of onkolite limestones (Celiny Onkolite Bed) (Fig. 4). The lateral facies transition between the oolites and micritic limestones is generally obvious: within the shallow-water carbonate platform the larger bodies of cross-bedded oolites formed submarine ridges, whereas the non-cross-bedded oolites, and especially the micritic limestones with ripples and streaks of fine-grained material (ooids, bioclasts, intraclasts) accumulated in the protected submarine shoals sheltered by the oolitic ridges (Kutek, 1969). Recognition of the detailed spatial and time relations between the discussed lithostratigraphic units, however, is more troublesome.

The studied succession of the Małogoszcz Oolite Formation begins with the micritic limestones of the Rogalów Limestone Member, lying directly on the marly deposits of the Góry Marl Member. These deposits are represented by micritic limestones, showing some intercalations of organodetrital and oolitic limestones, and becoming generally thicker in the northern (at Oleszno and Rogalów) and southern (at Sobków and Staniewice) parts of the study area, where they attain about 10-15 m thickness (Kutek, 1968). The limestones are much reduced in thickness in a central part of the study area, between Bukowa quarry (Skorków), Leśnica-Małogoszcz and Mieronice. In the Bukowa section, the whole unit attains only $2.6 \mathrm{~m}$ in thickness and consists of medium-bedded micritic limestones, followed by thin-bedded micritic limestones and marls, and showing thin intercalations of grained (mostly composed of ooids and bioclasts, lesss commonly intraclasts) limestones in its uppermost part (Matyja, 2011). When compared with the detailed section of the same unit from the southern part of the area of study at Sobków, as described by Chudzikiewicz and Wieczorek (1985, fig. 1), it can be showed that the general succession of the lithologies is very similar, but the total thickness of deposits is markedly larger there (about $9 \mathrm{~m}$ ). This indicates the differences in thickness of the coeval deposits of the Rogalów Limestone Member in the south-western margin of the Holy Cross Mts. It is remarkable that the larger thickness of the unit was generally observed outside the stronger de- velopment of the underlying marly deposits (Góry Marl Member), whereas the smaller thickness was recognized directly in the main area of deposition of this marly unit. These observations suggest some original (?inherited) differences in topography of the sea-bottom during sedimentation of the Rogalów Limestone Member. The same tendency is stated to occur in younger deposits, in accordance with the observations of Kutek (1969, p. 249), who recognized the occurrence of the Głuchowiec Oolite Member represented by large-scale cross-bedded oolite limestone sets, indicating the existence of widely distributed submarine ridges, just between Skorków and Małogoszcz, in the middle part of the area of study -i.e. where the deposits of the Rogalów Limestone Mbr. show their lowest thickness.

The Głuchowiec Oolite Member at Skorków attains about 20 meters in thickness and consists mostly of crossbedded oolites, although it shows also there the occurrence of non cross-bedded parts. In the large cement-works quarry at Małogoszcz as well as in Mieronice quarry these deposits have a smaller thickness (about 10 meters), but the whole unit is composed of cross-bedded oolites. The area of sedimentation of cross-bedded oolites between Skorków, Małogoszcz and Mieronice became subsequently covered by the limestones of the Mieronice Banded Limestone Member, most fully developed here (Kutek, 1969). At Mieronice the succession of this unit attaining about 20 meters in thickness consists of pure sublithographic limestones (about $5 \mathrm{~m}$ in thickness) below, and the overlying alternating bands of micritic limestones and fine-grained limestones, showing small-scale ripple-cross bedding (Kutek, 1962a). Such a succession of deposits from the cross-bedded oolites of the Głuchowiec Oolite Mbr. formed in a highly energy environment to the micritic limestones with small ripple-marks of the Mieronice Banded Limestone Mbr. deposited in a lowenergy zone, indicates the transition from external belts of submarine shoals towards inner sheltered areas. This facies pattern could have originated as a consequence of the moving in time of the oolitic ridges outside their place of primary origin, e.g. towards the north and south, whereas the sheltered area in between became the place where the micritic limestones with streaks and ripple-marks of fine-grained material were deposited. The lagoonal or even pond-like sabkha character of the area of deposition of the Mieronice Banded Limestone Member explains also the special shape of the commonly occurring cherts. The silica concentrated along the crustacean burrows which are similiar to those constructed by the present intertidal shrimp Alpheus (Radwański, 2003). Precipitation of silica was caused by the supersaturation of the sea-water inside the burrows, where the $\mathrm{pH}$ of the solution dropped sharply, which was associated with decay of organic matter (Pieńkowski, Gutowski, 2004). 
The lateral replacing of the quiet-water deposits of the Mieronice Banded Limestone Member by the oolites of the Głuchowiec Oolite Member has been recognized in several places in the study area. Such a transition is represented by a packet of oolites, about $10 \mathrm{~m}$ in thickness, recognized within the typical deposits of the Mieronice Banded Limestone Mbr., east of Bolmin, which disappears in northern and north-western directions (Pszczółkowski, 1970, figs. 2, 4). A similar situation was observed near Brzegi, where the deposits of the Mieronice Banded Limestone Mbr. showed especially common intercalations of oolitic limestones, or were developed as micritic limestones containing large share of ooid grains. The upper part of this unit is replaced in this area by oolites being possibly the age-equivalents of the lowermost part of the Sobków Oolite Mbr ("upper oolite") (Kutek, 1968, p. 511). Still another example of lateral facies change is seen in the succession at the top of the Mieronice Banded Limestone Member at Brzegi and Żerniki studied by Roniewicz and Roniewicz (1968). They recognized a flat coral biostrome, about $2 \mathrm{~m}$ in thickness, over a distance of at least $5 \mathrm{~km}$, showing in its lower part massive coral colonies in an oolitic matrix, followed at its top by a falceoid coral assemblage (of one species Calamophylliopsis stockesi) with coral branches surrounded by micritic matrix. The top of the biostrome was cut by the hardground surface, and the coral branches at the contact down to about $30 \mathrm{~cm}$ were completely dissolved, and the empty places infilled by micritic matrix or oolites. These features indicate that after the development of coral colonies in a shallow marine shoal of the quiet-water environment, the dissolution of coral colonies composed of aragonite took place as a result of the dilution of sea-water, possibly by rain-fall. The occurrence of the hardground surface at the top of the succession, and directly below the Sobków Oolite Member "indicates the re-starting of watermovements, this being the result of a slight deepening of the basin" (Roniewicz, Roniewicz, 1968, p. 384). The top of the Mieronice Banded Limestone Member shows also the occurrence of a distinct marly layer in the north-west direction from Gruszczyn, which also suggests a change in the sedimentation conditions (Pszczółkowski, 1970, p. 352).

The above discussed facies pattern of the Gluchowiec Oolite Member ("lower oolite") and the Mieronice Banded Limestone Member ("banded limestone member') refers mostly to the central part of the south-western margin of the Holy Cross Mts., especially from Gruszczyn in the north and Żerniki-Brzegi in the south (Kutek, 1968), or from Lipie to Karsznice (Pszczółkowski, 1970). In the northernmost part of the south-western margin (at Oleszno) and in the southern part (from Ostrów to Staniewice and Korytnica), the equivalents of the Mieronice Banded Limestone Member are micritic limestones, sometimes with an admixture of oolites, whereas the banded limestones with cherts typical of this unit almost completely disappear (Kutek, 1968, p. 511). This may indicate the original range of the very shallow-water areas and a transition to a somewhat deeper environment.

The hardground at the top of the Mieronice Banded Limestone Mbr. is considered to be one of the most important, and to have the larger range of the discontinuity surfaces in the Lower Kimmeridgian succession of the south-western margin of the Holy Cross Mts. The origin of such a surface could be ascribed to a minor change in the bathymetry, although occurring in a very shallow basin (Kaźmierczak, Pszczółkowski, 1968, p. 610, fig. 2; pl. 1: 1,2; pl. 3: 1; pl. 4: 2, 3; see also Figs. 4 and 7, herein).

The overlying Sobków Oolite Member ("upper oolite") shows marked lithological variation - from cross-bedded oolites to non-cross-bedded oolites, and to micritic limestones with a variable admixture of ooids, bioclasts, onkoids, and even to almost pure micritic limestones (Kutek, 1968, tab. 2; fig. 6). Although the recognition in detail of the distribution of particular types of facies is difficult - some observations suggest that cross-bedded oolites are not very common, and oolites occur mostly in some stratigraphical intervals only - especially in a lower part of the unit, such as at Sobków and Krasocin (Kutek, 1969, p. 252; Fig. 7, herein). The packets of micritic limestones up to few meters in thickness have been recognized locally over distances varying from a few hundreds of meters up to few kilometers, but their correlation over a larger distance is not possible (Pszczółkowski, 1970).

The deposits of the Sobków Oolite Member accumulated over a large shoal, the outer margins of which migrated in time possibly towards the west and south-west (Kutek, 1969). Relatively scattered oxygen and carbon isotope values suggest considerable variations in water temperatures and salinity resulting from fresh water influx and an enhanced evaporation rate along with changes in the input of terrestrial organic matter (Wierzbowski, 2019). Nevertheless, although of shallow-marine origin, when compared with the discussed underlying shallow-marine deposits of the Małogoszcz Oolite Formation, they show marked differences. Especially remarkable is the diversified faunal assemblage recognized in the Sobków Oolite Mbr. which consists of very numerous bivalves - from deep-infaunal to semi-infaunal, epibyssate, and to recline and cementing, and even to freeswimming forms (e.g. Pholadomya, Pleuromya, Astarte, Gervillia, Mytilus, Lima, Trichites, Ostrea, Nanogyra, Alectryonia $=$ Actinostreon, Plagiostoma, Entolium, Camptonectes), gastropods, brachiopods (both rhynchonellids and terebratulids), echinoids, crinoids etc. (Świdziński, 1962; Kutek, 1969; see also Fig. 7, herein), and last but not least ammonoids, indicating a normal marine environment. These features, together with less commonly occurring cross-bedded oolites, and more common micritic limestones suggest 


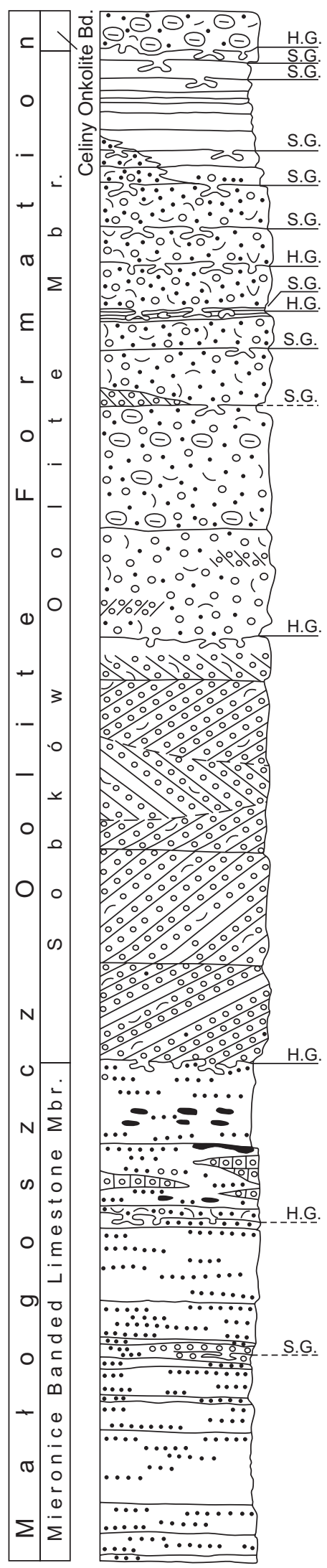

shell debris, Trigonidae, Plagiostoma, echinoids, ammonites, crinoids, Septaliphoria;

crinoids;

crinoids;

crinoids;

Trichites, Plagiostoma, Pleuromya, oysters, terebratulids, Septaliphoria, Trigonidae, crinoids, Nerineidae;

Trichites, Pholadomya, Pleuromya, Plagiostoma, Septaliphoria, Nerineidae, crinoids, ammonites;

Trichites, oysters, Pholadomya, Pleuromya, Plagiostoma, terebratulids, Septaliphoria, crinoids;

shell debris, Pholadomya, Pleuromya, Trichites, Mytilus, Plagiostoma, Septaliphora, terebratulids, crinoids;

shell debris, Trichites, Pholadomya, oysters;

shell debris;

\begin{tabular}{|c|c|c|}
\hline & & micritic limestones \\
\hline & $\because \because \because$ & fine-grained limestones \\
\hline shell debris; & $\begin{array}{lll}0 & 0 \\
\circ & 0 & 0 \\
& \end{array}$ & oolitic limestones \\
\hline & $\frac{\% \%}{\% \%}$ & $\begin{array}{l}\text { large-scale cross-bedded } \\
\text { oolitic limestones }\end{array}$ \\
\hline shell debris, Septaliphoria; & $\Theta \theta$ & onkolitic limestones \\
\hline & $\dot{j} \smile \grave{v}$ & organodetrital limestones \\
\hline & - & cherts \\
\hline shell debris; & H.G. & hardground surface \\
\hline 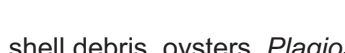 & S.G. & softground surface \\
\hline
\end{tabular}


Fig. 7. Detailed lithological log, showing the faunal content of the Mieronice Banded Limestone Mbr. ('banded limestone member'), the Sobków Oolite Mbr ("upper oolite") and the Celiny Onkolite Bd. ("onkolite horizon") of the Małogoszcz Oolite Formation in the south-eastern part of Sobków quarry (after Pastusiak, 1987)

a more quiet and somewhat deeper environment than that of the Głuchowiec Oolite Member ("lower oolite"). On the other hand, when compared with the directly underlying deposits of the Mieronice Banded Limestone Mbr., the deposits of Sobków Oolite Member, should be recognized as representing an open-marine and deeper environment. All these features suggest that the depositional environment of the Sobków Oolite Member represented a seaward-directed part of the oolite shoal (Matyja, 2011). Summarizing the observations on the succession of the Małogoszcz Oolite Formation, it possibly consists at its base of a transgressive segment corresponding to the Głuchowiec Oolite Member and its lateral counterparts (as well as underlying deposits of the Rogalów Limestone Mbr.), then follows a regressive segment (or the most shallow-water fragment) corresponding to the Mieronice Banded Limestone Member, and then the successive transgressive segment of the Sobków Oolite Member - all of them developed in a shallow-water succession of the carbonate-platform shoal.

As already indicated before (see chapter on Facies succession), the ammonites occurring in the upper part of the Sobków Oolite Member indicate the stratigraphical interval at the top of the Platynota Zone - the base of the Hypselocyclum Zone, being represented i.a. by very diagnostic forms of the subgenus Schneidia - ranging up into the lussasense horizon of the lowermost Hypselocylum Zone. This level showing features of stratigraphical condensation is also recognized in other sections of central Poland, such as the Wielun Upland and the Radomsko elevation, west of the area of study (Wierzbowski, 2017a; Wierzbowski, Głowniak, 2018). In the cyclostratigraphic correlation chart of south-eastern France, this level marks the top of the short (100-kyr) eccentricity cycle, being also the equivalent of the main flooding surface in the sequence stratigraphy scheme (see Boulila et al., 2008, fig. 2; Boulila et al., 2010, figs. 2, 3 ). The immediately following level of the MS (magnetic susceptibility) maximum (Max. 2), corresponding to the extremum of the long-term (405-kyr) cycle as recognized by Boulila et al. (2008, fig. 2) in south-eastern France, could be correlated with the lowermost part of the overlying marly deposits of the Spinkowa Góra Formation (Kiełczygłów Marl Member) showing already a regressive trend in the south-western margin of the Holy Cross Mts. (see also below). If all these cyclostratigraphical correlations have been done properly, the whole set of deposits corresponding to the Małogoszcz Oolite Formation was deposited approximately during a single short (100-kyr) eccentricity cycle (Fig. 6). Because the total thickness of these deposits attains about
60 meters, the rate of deposition may be calculated at about $60 \mathrm{~cm}$ during 1000 years. These data are comparable with those from the north-eastern margin of the Wielun Upland, where the coeval shallow-water carbonates with hermatypic corals (Kule Chalky Limestone Member) even attained over $100 \mathrm{~m}$ in thickness, also showing an extremely high sedimentation rate - about $1 \mathrm{~m} / 1000$ years (Wierzbowski, 2017a).

Towards the restricted environments - Hypselocyclum Chron. The Spinkowa Góra Formation is represented in its lowermost part by the Kiełczygłów Marl Mbr. - a distinctive few meters thick marly unit, which overlies the Celiny Onkolite Bed of the topmost part of the Małogoszcz Oolite Formation. This marly unit has yielded a fairly diversified microfaunal assemblage composed of abundant foraminifers along with some ostracods, holothurian sclerites, small bivalves and gastropods recognized in cores at $\mathrm{Bu}-$ kowa quarry (Alexandrowicz, Barwicz-Piskorz, 1974). This indicates that this unit, similarly as the Celiny Onkolite Bed, was deposited over a shallow shoal in a continuation of the marine conditions responsible for origin of the older oolitic limestones (Kutek, 1969), however, as suggested above, during a generally regressive trend.

The Spinkowa Góra Formation in the northern and central parts of the study area, down to Karsznice and Mieronice in the south, shows the presence of limestones directly above the Kiełczygłów Marl Member (Fig. 4). These limestones belong to the Grabki Limestone Member in its most typical development, and consist of micritic limestones with subordinate intercalations of organodetrital-oolitic-onkolitic limestones, sometimes also of oyster coquina beds with Alectryonia=Actinostreon and Nanogyra (Kutek, 1968, Pszczółkowski, 1970; Matyja et al., 2006a; Matyja, 2011). Some beds show Thalassinoides burrows infilled with oolitic material; a few local hardgrounds with bivalve borings and encrusted by oysters and serpulids are recognized in the middle part of the unit (Kaźmierczak, Pszczółkowski, 1968). The skeletal remains are not very common, and together with trace-fossils represent a rather monotonous faunal assemblage, composed mostly of bivalves and crustaceans, without cephalopods (Radwańska, Radwański in: Matyja et al., 2006a). The character of these deposits and their faunal content are not very diagnostic for an interpretation of the environment, although the absence of ammonites and the abundance of oysters, but also the dominance of micritic facies suggest its restricted character. The most important factor for recognition of the environment is, however, the character of coeval deposits and especially the occurrence of the oolitic 
limestones north and south of the discussed area of distribution of the Grabki Limestone Mbr. (Fig. 4).

Intercalations of oolitic limestones appear already within the Grabki Limestone Member at Oleszno and Rogalów in the north (Pszczółkowski, 1970), but still more towards the north, at Dobromierz, Mojżeszów, Suche Góry and Przedbórz, already outside the area of study, nearly all coeval deposits are developed as oolitic limestones (Kutek, 1968). Although, Kutek $(1968,1969)$ lumped all these deposits from Przedbórz in the north to the southernmost part of the area of study to his "oolite-platy member", the difference between those occurring in the northern part (as discussed above composed mostly of oolitic limestones) - which should be recognized in future as a separate oolite unit of member or formational rank, and those of the Grabki Limestone Member composed mostly of micritic limestones as distinguished herein, is distinct (Fig. 4).

The oolitic deposits occurring at the north-western margin of the Holy Cross Mts. stretch westward toward the Radomsko elevation as the "oolite of Smotryszów" as distinguished by Kutek (1968, fig. 11; see also Wierzbowski, Głowniak, 2018), and even further west to the BełchatówSzczerców area, including the "oolitic unit C" placed directly above the Kiełczygłów Marl Mbr. (see Wierzbowski, 2017a, fig. 5 ). The oolite limestones occurring in these areas are of early Hypselocyclum age, being younger than the lussasense horizon (Wierzbowski, 2017a; Wierzbowski, Głowniak, 2018), thus they cannot be correlated with the Małogoszcz Oolite Formation. The distribution of all these oolites strictly corresponds to the important tectonic zone of the Holy Cross Fault (lineament) - active during the Late Jurassic (see Matyja, Wierzbowski, 2014) and some adjoining faults in the south. The tectonic activity of these faults during the early Hypselocyclum Chron resulted in an elevation of the present south-western margin of the Holy Cross Mts. and adjoining areas from west and east, in relation to their northern foreland, which was possibly lowered. In consequence, this enabled the development of the shallow-water high energy zone of oolitic sedimentation which bordered from the north a more restricted environment of the carbonate platform, including the present distribution of the Grabki Limestone Member (Figs. 4-6).

Less clear is the relation between the Grabki Limestone Member and coeval deposits in the southern part of the south-western margin of the Holy Cross Mts. These deposits are micritic limestones with intercalations of oolitic limestones, especially well-developed between Karsznice, Sokołów Dolny and Sobków, but towards the south-east replaced by marly limestones. Still towards the south, oolitic limestones appear once more, attaining at Korytnica even 10 meters in thickness (Pszczółkowski, 1970). At Celiny, in the south-western part of the margin, this oolite unit is also
10 meters thick, being underlain by micritic limestones with marly intercalations, only $2.5 \mathrm{~m}$ thick, and resting directly on the Celiny Onkolite Bed of the topmost part of the Małogoszcz Oolite Formation (Kutek, 1968). It is remarkable that the Celiny Onkolite Bed is placed here higher in the succession, contouring the top of the underlying oolitic limestones of the Sobków Oolite Member, which attains also a larger thickness than towards the north (Kutek, 1968, tab. 2, p. 508). These data indicate the general tendency for the stronger development of oolitic limestones and suggests the occurrence of another large oolitic unit replacing laterally the Grabki Limestone Member in the southern part of the study area (Fig. 4). The origin of this unit and the corresponding sedimentary zone, similarly as that of the northern part of the area of study, could be related with synsedimentary tectonic activity, here possibly the Zawiercie-Busko Fault Zone, bordering the area of occurrence of the Grabki Limestone Member from the south (Fig. 5).

The upper part of the Spinkowa Góra Formation represents in the south-western margin of the Holy Cross Mts. another facies pattern. The northern and central parts of the area of study (Fig. 4) show a fairly uniform succession of marly deposits (Dobromierz Marl Member) and the overlying micritic ("sublithographic") limestones, showing very subtle lamination (Buczyna Limestone Member), both corresponding to the "shaly limestones and underlying clays" of Kutek (1968). They were deposited over a large shallowwater shoal with restricted circulation, being generally very poor in faunal remains, and revealing only occasionally some erosional surfaces. The faunal elements are extremely rare and specific, including the isopod Cyclosphaeroma and fragments of plesiosaur/pliosaur (Radwański, 1995), possibly representing exotic elements washed into an abiotic environment (Machalski, 1996); These deposits covered the older oolitic limestones towards the north (already outside the area of study, see Kutek, 1968, tab. 2), thus showing the subsidence of the northern zone of the oolite ridges active previously during sedimentation of the Grabki Limestone Member. Still towards the north and north-west the coeval deposits were marls and onkolitic limestones occurring in the Wielun Upland, and its northern borders up to the Bełchatów-Szczerców area (see Wierzbowski, 2017a, units E, F, figs. 4-6). The latter deposits have yielded ammonites of the upper part of the Hypselocyclum Zone - the Lothari Subzone, but below its uppermost part. The data suggest the occurrence of a wide shallow-water shoal of restricted water circulation covering during the late Hypselocyclum Chron a large part of the area of study and directly inclined towards the north in the form of a shallow-water carbonate ramp, which gently came into a more deeper and open marine environment, where the deposition of marls and onkolitic limestones occurred. On the other hand, the southern border 
of the shoal was marked by oolitic limestones, occurring commonly near Gołuchów, Korytnica, Karsy and Wymysłów (Kutek, 1968, tab. 2; Pszczółkowski, 1970, p. 355, fig. 3). These oolitic limestones represented the continuation in time of the older highly dynamic shallow-water zone (Fig. 4), possibly related with activity of the Zawiercie-Busko Fault Zone.

The whole succession of the Late Oxfordian to Early Kimmeridgian shallow-water carbonate platform deposits in south-western margin of the Holy Cross Mts. has been treated as the upper regressive fragment of the COK sequence by Kutek (1994, 1996), having the character of a "tectonostratigraphic unit" (i.e. without any relation to its eustatic origin). The overlying deposits of the next LUK sequence are represented at the base by the transgressive oyster coquinas (Skorków lumachelle of Kutek, 1968). The base of the Skorków lumachelle is placed near the boundary of the Hypselocyclum and Divisum zones of the upper part of the Lower Kimmeridgian (Kutek, 1968, 1994; Matyja, Wierzbowski, 2000).

The distribution of the shallow-water carbonates in central Poland was strictly related to the elevated part of the Northern Tethyan Shelf - the so-called "Meta-Carpathian Arch" sensu Kutek (1994, 1996), because further towards the south, beyond the Zawiercie-Busko Fault Zone, the deep-neritic sponge megafacies and the following marly facies existed up to the Early Tithonian (Matyja, 2009). The north-western part of the elevated area in central Poland, mostly at the northern border of the Wielun Upland and adjoining areas, represented a more external zone of the carbonate platform at the transition to the open-marine Polish Basin (e.g. Matyja, Wierzbowski, 2014). Here, the successive segments of the shallow-water carbonate platform became covered much earlier by the transgressive open-marine carbonates with ammonites belonging to the Burzenin Formation, beginning in the earliest Hypselocyclum Chron (Wierzbowski, 2017a, fig. 13). A similar situation occurred also in some areas of northern Poland (Kujawy area), although in the central part of the basin outside the range of the shallow-water carbonate platform, where carbonate deposits comparable with the Burzenin Formation appear in the lower part of the Hypselocyclum Zone, directly above the siltstones and silty limestones of the Lyna Formation (Matyja, Wierzbowski, 1998, fig. 3). The appearance of the transgressive deposits of the LUK sequence already in the earliest Hypselocyclum Chron, much earlier than in the south-western margin of the Holy Cross Mts., thus shows evidently the diachronous character of the lower boundary of the sequence and confirms its tectono-stratigraphic status (Kutek, 1994; Wierzbowski, 2017a).

In such a context, the tectonic deformation of the southwestern margin of the Holy Cross Mts. and the adjoining ar- eas along the northern tectonic zone of the Holy Cross Fault during the Hypselocyclum Chron as suggested above could be related also to the successive stage of subsidence of the "Meta-Carpathian Arch". This northern tectonic zone, being the place of formation of the shallow-water oolite ridges during the early Hypselocylum Chron and sedimentation of the Grabki Limestone Member behind, subsided during the late Hypselocyclum Chron. The restricted shallow-water deposits of the Dobromierz Marl Member - Buczyna Limestone Member initially represented a wide zone bordered by the southern shallow-water zone of oolite ridges. A special episode in sedimentation took place during the late Hypselocyclum Chron, when the areas lying directly north of the study area subsided along the tectonic zone at DobromierzŻeleźnica: in consequence, the youngest deposits of the Buczyna Limestone Member along this zone were supplied by debris-flowed carbonate deposits sourced from the adjoining and newly elevated area (see Fig. 8; see also description of the Buczyna Limestone Member herein, but this aspect will be discussed in detail in the second part of the study). Soon thereafter, the whole study area subsided at the boundary of the Hypselocyclum and Divisum chrons. The subsidence resulted in the appearance everywhere of the transgressive deposits of the Skorków lumachelle, which completely covered the shallow-carbonate platform of the south-western margin of the Holy Cross Mts. at the end of the Hypselocyclum Chron - beginning of the Divisum Chron (Matyja et al., 2006a). It opened a new stage in the history of sedimentation.

\section{DISCUSSION AND REGIONAL CORRELATIONS}

The sedimentary record placed in biochronostratigraphical frames yields new data on the depositional environments during the origin, development and decline of the shallowwater carbonate platform of the Early Kimmeridgian in the south-western margin of the Holy Cross Mountains, and offers possibilities for comparison with other coeval deposits in Polish areas (Wielun Upland) and in Europe (Jura Mountains).

Summary on facies development and comparison with the Wieluń Upland foreland. The studied south-western margin of the Holy Cross Mountains represents a part of the original sedimentary zone of the shallow-water carbonate platform of south-eastern Poland ( $c f$. Matyja, Wierzbowski, 2006a), however, showing some special features in facies development from the Planula Chron to the Hypselocyclum Chron, when compared with other areas (Fig. 4). The cause of this was due to the specific interaction between the range of climatic and tectonic settings: climatic fluctuations of a wider character were reflected directly in changing 




Fig. 8. Detailed lithological log of the Buczyna Member of the Spinkowa Góra Formation in the Dobromierz Anticline (after Wierzbowski, 1961)

facies similarly as in other areas, whereas the superimposed tectonics caused local facies changes through relative vertical movements.

The tectonic setting resulted from the presence of synsedimentary active faults bordering the studied shallow-wa- ter sedimentary zone of the south-western margin of the Holy Cross Mts. - the Zawiercie-Busko Fault Zone in the south and the Holy Cross Fault System in the north (Fig. 5). The latter represented by a western prolongation of the main fault zone was supposed to run "somewhat north of the Do- 
bromierz Anticline" (Hakenberg, 1980, p. 476), whereas a possible branch stretched somewhat obliquely, and directly south of the Dobromierz Anticline and the Józefów Syncline, along the northern border of the study area (see also Fig. 2, herein). The Holy Cross Fault crossed the Grójec Fault Zone at the Radomsko elevation, and continued in WNW direction towards the northern border of the Wielun Upland (Matyja, Wierzbowski, 2014; Wierzbowski, 2017a; Wierzbowski, Głowniak, 2018). On the other hand, the Grójec Fault Zone stretched south-westwards, coming into the Warta river valley, representing the tectonic border between the Częstochowa Upland and the Wielun Upland of the Polish Jura range within the Silesian-Cracow Monocline (Barski, 2012; Matyja, Wierzbowski, 2014; Wierzbowski, 2017a). Such a continuation of the synsedimentarily active tectonic boundaries resulted probably in a prolongation of the discussed fragment of the shallow-water sedimentary zone of the south-western margin of the Holy Cross Mts. to the west onto the the northern part of the Laramian Miechów Synclinorium area, where Kimmeridgian carbonate deposits, comparable at least partly to those of the area of study, have been penetrated in cores: such as the Wegleszyn IG-1 and Jaronowice IG-1 cores (Jurkiewicz et al., 1969, fig. 3; see also Fig. 5, herein), but also in several other cores studied by the author. An opinion on the close similarity of the shallow-water Kimmeridgian deposits in the cores in the Miechów Synclinorium ("Nida Trough") and those of the south-western margin of the Holy Cross Mts. was presented also by Złonkiewicz (2009). Early Cretaceous differential tectonic movements within the Miechów Synclinorium area combined with lithological variations in the Jurassic substrate and its erosion resulted, however, in the partial preservation of the original Kimmeridgian deposits, generally younging towards the north-east and north-west, and occurring below the transgressive Late Albian-Early Cenomanian sandy deposits (Hakenberg, 1978). The discussed shallowwater sedimentary zone of the Kimmeridgian also probably continued further westward onto the northern part of the Cracow-Silesian Monocline (northern part of the Częstochowa Upland), where the only preserved shallow-water carbonate deposits with hermatypic corals, at the tops of older cyanobacteria-sponge bioherms, and of the chalky limestone type, similar to those of the the Bukowa Formation, are known from Julianka, Bystrzanowice and Złoty Potok in the north to Sokolniki and Dzibice in the south, all in the lower Platynota Zone (Roniewicz, Roniewicz, 1971; Matyja, Wierzbowski, 1996; Roniewicz, 2004; Matyja, Wierzbowski, 2006b; Matyja, 2015; Fig. 5). On the other hand, the prolongation of the discussed zone of shallow-water Kimmeridgian deposits of the south-western margin of the Holy Cross Mts. onto its Palaeozoic core to the east (pre- sently devoid of Jurassic deposits) seems also highly probable (Kutek, 1969).

The Wielun Upland located in between the western fragment of the Grójec Fault Zone - from the south, and the western prolongation of the Holy Cross Fault System - from the north, represented an area of a relatively deeper environment from the late Planula Chron to the early Hypselocyclum Chron. Here, the biostromal chalky limestones with siliceous sponges and deeper-water Microsolena corals (showing presumably adaptation to a filtering mode of nutrition, see Roniewicz, 2004), micritic limestones and marls of the Prusicko Formation sedimented in a wide embayment which opened to a deeper marine basin to the west, between the shallow-water carbonate platforms in the Szczerców-Bełchatow area situated in the north, and the shallow-water carbonate platform area discussed herein to the south (see Wierzbowski, 2017a).

The oolitic-onkolitic shoals of limited distribution which preceded the encroaching carbonate platform, were related possibly to the tops of older cyanobacteria-sponge biohermal complexes during the Planula Chron in the south-western margin of the Holy Cross Mts. (Matyja et al., 1989; Matyja, 2011). The uniform progradation of the carbonate platform over the whole south-western margin was strictly related to two major factors: (1) the origin of the discontinuity surface at the top of the Siedlce Limestone Member of the Pilica Formation, and the appearance of high turbulence events which resulted from the accelerated shallowing of the basin; and (2) the subsequent deepening of the basin which gave space for accumulation of the directly younger deposits of the Bukowa Formation. The former was possibly controlled by the tectonic elevation of the Holy Cross Mountains area at the end of the Planula Chron, and the related export of large amounts of the marly/siliclastic material of the Latosówka Marl Member onto the foreland of the carbonate platform such as the Wielun Upland ( $c f$. Matyja et al., 1989; Matyja, Wierzbowski, 2016; Wierzbowski, 2017a; see also Figs. 4 and 6, herein). The latter induced possibly by orbitally controlled climatic changes of the 405 kyr eccentricity cycle at the boundary of the Planula and Platynota chrons resulted in an increase in sea-level (cf. Boulila et al., 2008, 2010; see also Wierzbowski, 2017a). After deposition of the Piekielnica Limestone Member with its commonly occurring hermatypic corals, indicating a moderately shallow and rather quiet environment at the beginning of the Platynota Chron, the next horizon with fairly common ammonites is dated to the end of the Polygyratus Subchron - beginning of the Desmoides Subchron of the Platynota Chron. This horizon was also climatically controlled, corresponding to the MS minimum of the 405-kyr eccentricity cycle, as recognized in the Wielun Upland in 
the foreland of the carbonate platform in central Poland, but also in the basinal succession of SE France ( $c f$. Atrops, 1982; Boulila et al., 2008, 2010). The final stage of development of the Bukowa Formation in the south-western margin of the Holy Cross Mts. is represented by the influx of the marly/siliclastic deposits of the Góry Marl Member ("lowermost marly unit") during the middle Platynota Chron, possibly controlled by climatic factors but superimposed on the next tectonic activity, and seen also in the Wielun Upland (see chapter on history of sedimentation).

It appears that the succeeding sedimentation of the Małogoszcz Oolite Formation corresponded to a single 100-kyr eccentricity cycle, as bordered from the base and the top by the two transgressive climatically-controlled levels marked by the fairly common occurrence of ammonites (including some of Subboreal affinity). These levels are situated somewhat before the beginning of the Guilherandense Subchron of the late Platynota Chron below, and, directly at the lussasense horizon of the early Hypselocyclum Chron above (Fig. 6). The rate of shallow-water carbonate sedimentation was extremely high, something that is observed both in studied area of the Holy-Cross Mts. (about $0.6 \mathrm{~m} / 1000$ years), as well as in coeval shallow-water carbonates at the northern margin of the Wielun Upland (about $1 \mathrm{~m} / 1000$ years) (see Wierzbowski, 2017a). Sedimentation was controlled at that time by the minimal influx of siliciclastic material and the subtropical climate.

A marked influx of siliciclastic material occurred at the beginning of the sedimentation of the Spinkowa Góra Formation, when the marly deposits of the Kiełczygłów Marl Member show a wide palaeogeographical distribution. This event took place during the early Hypselocyclum Chron, and was at least partly controlled by tectonic activity. This resulted in the topographical reconstruction of areas of the carbonate platform in south-eastern and central Poland: such as the formation of active edges to the shoals in the Szczerców-Bełchatów and adjoining Wieluń Upland areas, where oolitic deposits were formed ( $c f$. Wierzbowski, 2017a), and the development of the more restricted inner platform environment of the south-western margin of the Holy Cross Mts., where the micritic limestones of the Grabki Limestone Member were situated behind the oolitic barriers (Figs. 4, 6). The still younger times of the Hypselocyclum Chron were marked by the successive limitation of the distribution of the restricted inner platform environment in the south-western margin of the Holy Cross Mts., and the development of more open-marine conditions related to the tectonic subsidence of the elevated areas of the Meta-Carpathian Arch ( $c f$. Kutek, 1994; Wierzbowski, 2017a).

Comparison with shallow-water succession of the Jura Mts. All these phenomena already discussed in relation to the development of sedimentation in the foreland of the shallow-water carbonate platform at the Wielun Upland and adjacent areas, central Poland, have their equivalents also in other successions. Additionally, an attempt to correlate the discussed succession of the south-western margin of the Holy Cross Mts., with that of the shallow-water carbonate succession of the Jura Mountains in northern Switzerland (cf. Gygi et al., 1998; Gygi, 2000, 2003; Jank et al., 2006a-c; Comment et al., 2015) and south-eastern France (Enay et al., 1988; Enay, 2000) provides a further opportunity to test some of the above discussed concepts of climatically-controlled sedimentary cyclicity versus tectonic activity over wider areas. It should be noted that these areas of the Jura Mts. at the Swiss/French border represent the development of a shallow-water carbonate platform in a similar tectonic setting to that of the south-western margin of the Holy Cross Mts, both placed on the northern peri-Tethyan shelf.

The discussed shallow-water carbonate succession in Poland corresponds to the lower part of the Reuchenette Formation of northern Switzerland. The base of this formation is poorly documented biostratigraphically. It is placed at the top of the Courgenay Formation (Porrentruy Mbr.), and at the top of the Balsthal Formation (Verena Mbr.) representing the inner parts of the carbonate platform. The lower part of the Reuchenette Formation distinguished in the innermost part of the platform as the Vanbenau Member at Ajoie includes in its lowermost part the Thallassinoides Limestones (Jank et al., 2006a-c; Comment et al., 2015). This limestone unit is very poorly fossiliferous and it does not yield any ammonites. The base of the unit was, however, interpreted as a sequence boundary in terms of sequence stratigraphy, and correlated with the K1 level of Hardenbol et al. (1998) near the Planula/Platynota zone boundary (Jank et al., 2006a). Additionally, the lithostratigraphical correlation with the neighboring succession cropping out at Montbéliard in France which yielded the ammonite Pictonia thurmanni (Contejean), being close to Pictonia perisphinctoides (Wegele), gives support for an interpretation of the lower part of the Reuchenette Formation as corresponding to some upper parts of the Planula Zone ( $c f$. Comment et al., 2015; see also Schweigert, Callomon, 1997). The boundary between the massively bedded limestones of the Verena Member of the Balsthal Formation and the base of thinly bedded limestone and marls of the lowermost Reuchenette Formation in northern Switzerland was correlated using mineralogical criteria (Gygi, Persoz, 1986), but also on the occurrence of a single ammonite, Orthosphinctes (Lithacosphinctes) evolutus (Quenstedt), found in the lower part of the Reuchenette Formation, and interpreted as indicative of the lower part of the Platynota Zone [Gygi, 1995; it may be noted, however, that this species occurs in the uppermost part of the Planula Zone as well (e.g. Wierzbowski, 2017a)]. This 
ammonite was found $2.6 \mathrm{~m}$ below the palaeosol, which is correlated with the intertidal stromatolite in other sections, but also with a level containing a marked admixture of terrigenous material - generally treated as indicative of the sequence boundary (Gygi et al., 1998). At least the lowermost part of the Reuchenette Formation is correlated with the near basal deposits of the Baden Member of the Schwarzbach Formation of the basinal succession of Aargau at Schaffhausen in northern Switzerland. These yielded numerous ammonites indicating stratigraphical condensation at the top of the Planula Zone (including the Galar Subzone) (Gygi, 1990) which is interpreted as corresponding to the maximal flooding surface (Gygi et al., 1998). Summarizing, the data given indicate that the lowermost deposits of the Reuchenette Formation correspond to a stratigraphical interval at the boundary between the Planula Zone and the Platynota Zone (including the Galar Subzone, as interpreted herein), but also suggests some problems in the unequivocal interpretation of these deposits in terms of sequence stratigraphy.

The southern part of the Jura Mountains in France shows the succession of the Planula and Platynota zones composed generally of more-open marine deposits ("calcaires pseudolithographiques"), being laterally replaced, and also successively covered by more shallow-water deposits ("oolithe de Corveissiat" and "calcaires d'Aranc") (Enay, 2000, fig. 3). The boundary between the Planula Zone and the Platynota Zone corresponds approximately to the boundary between the "calcaires pseudolithographiques" below and the progradationally stretching overlying oolitic and oncolitic limestones ("oolithe de Corveissiat", and "calcaires d'Aranc", respectively), which are laterally replaced towards the southeast by the cephalopod-bearing beds ("couches à cephalopodes') (see Enay, 2000, fig. 4; cf. also Enay et al., 1988). Thus, here also, similarly as in the northern Jura Mts. in Switzerland, and in the south-western margin of the Holy Cross Mts., the marked change in facies revealed by occurrence of very shallow-water deposits occurs near the Planula and Platynota zone boundary. The discussed facies change is recognized over wide areas which suggests it was controlled either by tectonic uplift along the northern Tethyan margin as assumed herein, and possibly additionally modified by eustatic changes of sea level. Anyway, it can be mentioned that this stratigraphical interval, corresponding to the lowermost Reuchenette Formation in northern Switzerland, has been distinguished because of its special facies development as the beginning of the "second order minor regressive cycle (period)" in terms of sequence stratigraphy by Gygi et al. (1998).

The problem of climatically-controlled sedimentary cyclicity is strictly related with the occurrence of ammonite faunas at some horizons interpreted as indicative of a higher sea-level. In central Poland (Wieluń Upland, south-western margin of the Holy Cross Mts.) such a character shows an ammonite fauna appearing near the boundary of the lower and middle parts of the Platynota Zone (i.e. between the Polygyratus and Desmoides subzones) which is referred to the minimum (Min.2) of the 405-kyr eccentricity cycle (see chapter on history of sedimentation herein). A similar character is shown by the ammonite horizon $\mathrm{C} 1$ with Orthosphinctes (Lithacosphinctes) cf. janus and Physodoceras circumspinosum occurring in the middle lithostratigraphical unit (Couches de Creugenat or "Nautilidenschichten") of the Vabenau Member of the Reuchenette Formation at Ajoie in northern Switzerland (Jank et al., 2006a-c; Comment et al., 2015); this ammonite horizon referred to the Rupellense Zone of Hantzpergue (1979) is directly followed by the virgatoides horizon recognized in other sections of southern France, and interpreted as representing the maximum searise onto the western European shelf (Hantzpergue, 1995). The ataxioceratid ammonites of the discussed ammonite horizons have been interpreted as being very close to those occurring at the boundary of the lower and middle parts of the Platynota Zone (Atrops, 1982). Another example has yielded the assemblage of ammonites, representing the middle part of the Platynota Zone (Desmoides Subzone) from the Molignes area in the southern Jura Mountains in France as discussed by Enay (2000, pl. 1: 1-5); it includes a very characteristic species, Orthosphinctes (Ardescia) enayi Atrops, indicative of the boundary horizon between the lower and middle part of the Platynota Zone ( $c f$. Atrops, 1982). Although the unequivocal regional location of this fauna in the succession is difficult, its occurrence seems to be "a combination of sea-level rise and storm waves which have caused empty shells to drift far away" into inner parts of the carbonate platform possibly due to the activity of tropical storms (Enay, 2000). These data suggest the coeval occurrence of the ammonite faunas within the shallow-water carbonate platform successions in all the discussed areas, indicating the especially high sea-level near the boundary of the lower and middle parts of the Platynota Chron.

Another problem concerning the distribution of the ammonite faunas is related to the occurrence of the Subboreal aulacostephanids of the genus Rasenia and related Pachypictonia in the narrow stratigraphical interval of the shallowwater carbonate successions in the Jura Mountains in northern Switzerland and in the Holy Cross Mountains in Poland. Ammonites of the genus Rasenia, including Rasenia cymodoce (d'Orbigny), are known from northern Switzerland from the middle part of the Couches de Creugenat (ammonite horizon C2). Younger deposits of the lower part of the "calcaires à ptérocères infèrieurs" (lower grey and white limestones) (ammonite horizon C3) of the Vabenau Member of the lower part of the Reuchenette Formation have yielded the ammonite Ardescia cf. pseudolictor (Choffat) and additionally a form referred to as Eurasenia balteata (Schneid) 
to the virtual absence of Subboreal Rasenia (Jank, 2006 a-c; Comment et al., 2015). These two ammonite horizons have been referred to the lower part of the Subboreal Cymodoce Zone (Comment et al., 2015). Ammonites of Subboreal affinity are present also in the south-western margin of the Holy Cross Mts., especially in the Małogoszcz Oolite Formation, in deposits referred to the upper part of the Submediterranean Platynota Zone and the lowermost part of the Hypselocyclum Zone (lussasense horizon). These are mostly specimens of late Pictonia (Pomerania) smoothly passing into Pachypictonia and representing an offshoot of the Subboreal Pictonia-Rasenia lineage as interpreted herein (see discussion in Appendix 2 on ammonite palaeontology); they are associated with rare specimens of typical Subboreal $R a$ senia like Rasenia inconstans Spath. Additionally, some ammonites of a more Submediterranean character placed either in the genus Eurasenia or in the genus Pachypictonia like Pachypictonia balteata (Schneid) in common with the Swiss sections were described also from deposits of the lussasense horizon of the lowermost Hypselocyclum Zone in the Radomsko elevation in central Poland (Wierzbowski, Głowniak, 2018).

It is important to state that Subboreal ammonites of the genera Pachypictonia and Rasenia virtually do not range above the lower Hypselocyclum Zone, neither in the southwestern margin of the Holy Cross Mts. (i.e. the Sobków Oolite Member of the Małogoszcz Oolite Formation), nor in any other section in central Poland. Everywhere there appear additionally at the top of the succession numerous representatives of Submediterranean aulacostephanids (Eurasenia, Involuticeras), associated with ataxioceratids represented by early Ataxioceras and even rare aspidoceratids (see discussion in chapter on facies succession and stratigraphy herein; see also Wierzbowski, 2017a; Wierzbowski, Głowniak, 2018). The youngest assemblage of aulacostephanids from the Celiny Onkolite Bed at the top of the Małogoszcz Oolite Formation in the south-western margin of the Holy Cross Mts. is composed entirely of Submediterranean genera/subgenera like Eurasenia and Involuticeras (cf. Kutek, 1968, and data given herein). The younger assemblage of aulacostephanids in other areas of central Poland yielded, beside the dominant Submediterranean forms, rare specimens of Subboreal affinity, such as Pictonia constricta Schneid, a form somewhat transitional to the genus Rasenia (see Wierzbowski, 2017a). This species occurs e.g. in the "oolite of Smotryszów" on the Radomsko elevation (Kutek, 1968; Wierzbowski, Głowniak, 2018), which is a lithostratigraphical unit younger than the Małogoszcz Oolite Formation, placed at the boundary of the lower and upper part of the Hypselocylum Zone.

When considering the ammonite assemblages from the Jura Mts. of northern Switzerland, and from the Holy Cross
Mts. of central Poland, additionally some comments should be given on the distribution of ammonites in the coeval shallow-water carbonates of northern Aquitaine in western France. The lowermost beds of Aquitaine belonging to the lower part of the Cymodoce Zone have yielded Subboreal Rasenia cymodoce (d'Orbigny) (the lectotype of the species is derived from here), but the directly overlying deposits attributed to ammonite horizons C3 and C4 of Hantzpergue $(1989,1995)$ show the presence of ammonites having Submediterranean roots. The latter represented by oppeliids, ataxioceratids and aspidoceratids developed in the intermediate area between the Submediterranean and the Subboreal bioprovinces (Hantzpergue, 1989, 1991, 1995). A special ammonite recognized here which gave its name to the ammonite horizon (Hantzpergue, 1991) is Ardescia pseudolictor (Choffat). This ammonite originally described from Portugal has a poorly recognized stratigraphical range - being known from the "Marnes d'Abadia", ranging stratigraphically from the middle part of the Platynota Zone to the Hypselocyclum-Divisum zones (see Hantzpergue, 1989, 1991). Of marked stratigraphical importance, however, is the occurrence in northern Aquitaine of ammonites belonging to the genus Ataxioceras, being very close to the subgenus Schneidia (see Hantzpergue, 1991, fig. 5; pl. 1: 7-9). The co-occurrence of Ardescia pseudolictor with Ataxioceras very closely related to the subgenus Schneidia (Hantzpergue, 1991, fig. 1), indicating the stratigraphical interval from the Aquitaine Basin after the decline of Subboreal ammonites of the genus Rasenia, corresponds to the upper part of the Platynota Zone - the lowermost Hypselocyclum Zone. The succession of ammonite faunal assemblages in the shallow-water carbonates of the Holy Cross Mts. (central Poland), the Swiss Jura Mts., and northern Aquitaine is thus everywhere similar, being characterized initially by the predominance of ammonites of Subboreal origin (Rasenia and its allies), successively replaced by ammonites of Submediterranean origin (especially ataxioceratids, having the largest stratigraphical importance).

The discussed occurrence of Subboreal aulacostephanids in the Submediterranean European successions was for the first time recognized in Aquitaine, where the abrupt arrival of Rasenia cymodoce has been treated as reflecting an invasion from the north (Hantzpergue, 1989, 1995, and earlier papers cited therein; Birkelund et al., 1983). The coeval or almost coeval migration of these ammonites occurred towards the south-east into the Paris Basin and the Swiss Jura Mts. areas, and then north-east especially to the northern Franconian $\mathrm{Alb}$, from where numerous aulacostephanids were described by Schneid $(1939,1940)$. However, the character of the ammonite fauna changed markedly along the migration route: in the Franconian Alb the dominant forms became large-sized "German" late Pictonia (Pomerania) to 
Pachypictonia, representing possibly lateral equivalents of late Pictonia to early Rasenia modified by heterochrony possibly by the prolongation in the duration of shell growth (cf. Appendix 2, herein). The same forms migrated through the Bohemian Massif almost completely covered by the Late Jurassic seas (Valečka, 2019) to central Poland to the carbonate platform of the Holy Cross Mts. (cf. Kutek, 1962b, 1968).

As an aside from this discussion, it should also be noted that another coeval migration route of Subboreal ammonites of the genus Rasenia occurred deep into the Boreal Province, ranging through northern Norway, Svalbard and the Barents Sea (Wierzbowski, Smelror, 2020), thus showing a very wide range of migration during the early Cymodoce Chron. The discussed migration of Subboreal ammonites, which occurred during this relatively short time interval, could be tectonically induced and/or related to an overall transgressive phase. Tectonic rifting and relative sea-level rise resulted in the flooding of previously elevated areas in the Arctic enabling the flourishing of Rasenia assemblages in Boreal areas (Wierzbowski, Smelror, 2020). This transgression opened also new sea-routes and enabled migration of the Rasenia ammonites into the Submediterranean Province as discussed above. This is in accordance with the occurrence of the southward flowing cold current through the Laurasian Seaway and the Hebrides Basin during the early Cymodoce Chron (cf. Vickers et al., 2020) which could have brought the Subboreal Rasenia ammonites to the western Aquitaine (Hantzpergue, 1989) and further south-east and east down to central Poland.

On the other hand, approximately at the same time in more eastern European areas, a general warming of the climate occurred. It was recognized in the southern North Sea by a study of the terrestrial floral assemblages (Abbink et al., 2001), but also at the south-eastern rim of the Fennoscandian Land, in the Peri-Baltic Syneclise of north-eastern Poland by the common occurrence of Submediterranean ammonites of the family Ataxioceratidae (Wierzbowski et al., 2015). Although the postulated increase in sea-water temperature during Early Kimmeridgian on the northern Russian Platform as assumed by the decrease in $\delta^{18} \mathrm{O}$ values (e.g. Zakharov et al., 2005) was in fact an effect of decreased sea-water salinity (Wierzbowski H. et al., 2018), the change in distribution of the ammonite faunas during the early $\mathrm{Cy}$ modoce Chron is remarkable. It includes, besides the discussed Rasenia ammonites in the Arctic (Wierzbowski, Smelror, 2020), the spectacular occurrence of the "German" Pachypictonia ammonites in the northern part of the Russian Platform (Głowniak et al., 2010) and even in East Greenland (Birkelund, Callomon, 1985). Thus, approximately at the same time as when the cold southward flowing current in NW Europe was postulated, the existence of an- other northward flowing warm current possibly through the present North Sea area and/or east of the Fennoscandian Landmass could be proposed.

Summarizing, the rapid development of the shallow-water carbonate succession, such as that corresponding to the Małogoszcz Oolite Formation in the south-western margin of the Holy Cross Mountains, resulted in the appearance of the shallow-water, strongly contrasted facies pattern suitable for the development of aulacostephanids ( $c f$. Fürsich, Sykes, 1977). The successive replacement of the Rasenia faunas by the Pachypictonia (and related Pomerania) faunas along the Submediterranean migration route was possibly related to heterochronic changes reflecting successive adaptations of the aulacostephanid migrants to the distant, highly unstable environment of the shallow-water carbonate platform ( $c f$. Wierzbowski, 2019). The concentration of ammonites at the top of the Sobków Oolite Mbr. of the Małogoszcz Oolite Fm. in the south-western margin of the Holy Cross Mts. is representative of the lowermost part of the Hypselocyclum Zone - the lussasense horizon. It is treated herein as corresponding to the high sea-level of the 100-kyr eccentricity cycle (see discussion herein), and marking the temporary partial drowning of the carbonate platform (see Matyja et al., 2006a). The boundary between the corresponding levels $\mathrm{C} 3$ and $\mathrm{C} 4$ in the Aquitaine Basin (the achilles and pseudolictor horizons) has been treated as the "main flooding surface" level, whereas the pseudolictor horizon has been treated as the representative of the "high system track" in the terms of sequence stratigraphy by Hanztpergue (1995). This is generally in accordance with the interpretation of that part of the succession as given herein. The transgression at the beginning of the Hypselocyclum Chron was possibly responsible for the successive disappearance of the Subboreal aulacostephanids, which became replaced by the Submediterranean ataxioceratids and associated Submediterranean aulacostephanids. This, as well as the subsequent changes in environment, marked a new stage in the development of the shallow-water carbonate platforms.

The decline of the shallow-water carbonate platform in the south-western margin of the Holy Cross Mountains resulted mostly from the tectonic subsiding of the elevated Meta-Carpathian Arch during the late Hypselocyclum and early Divisum chrons at the transition between the COK and the LUK tectono-stratigraphic sequences (see Kutek, 1994; see also comments herein). The transgressive Skorków lumachelles are often represented by concentrations of the oyster shells of Actinostreon ("Lopha/Alectryonia") and $\mathrm{Na}$ nogyra and diverse other fossils, including ammonites, showing an open-sea environment, but indicating episodes of non-deposition, winnowing and reworking (e.g. Seilacher et al., 1985; Machalski, 1993, 1998; Radwańska, Radwański in: Matyja et al., 2006a). A similar character is shown by the 
Banné Member of the lower Reuchenette Formation in the northern Switzerland Jura Mountains. This unit, showing at its base a well-developed discontinuity surface of the hardground type, is composed commonly in its lower part of oyster shells (both Nanogyra and Actinostreon) and other associated fossils, showing signs of reworking and winnowing.

The Banné Member is referred to the Chatelaillonensis Subzone of the upper part of the Cymodoce Zone, and/or the Divium Zone (Jank et al., 2006a-c; Comment et al., 2015; cf. also Matyja, Wierzbowski, 2000), being thus of similar age as the discussed deposits of the Skorków lumachelles in the Holy Cross Mts.. When compared with the older deposits of the Reuchenette Formation formed under the flat carbonate platform topography, the Banné Member was deposited during "prominent basin-and-swell morphology" which was "probably related to enhanced synsedimentary subsidence across Late Palaeozoic basement structure" (Jank, 2006 b, p. 260, 261). The wide development of the basinal "couches à cephalopods" in the southern Jura Mountains in France shows also its maximum extension onto the carbonate platform deposits during the Divisum Chron (e.g., Enay, 2000, fig. 3). These examples suggest the approximately coeval time of subsidence of large blocks of the shallow-water carbonate platforms such as those in central Poland, northern Switzerland and south-eastern France. This phenomenon of large regional extent during the late Early Kimmeridgian was possibly tectonically controlled along the outer margin of the northern Tethyan shelf in central and southern Europe.

Acknowledgements. This study resulted from detailed analysis of the previously published materials of several authors to the relatively smaller attendance of the author in regular field-studies of the Upper Jurassic in the south-western margin of the Holy Cross Mts. Nevertheless, close contact with the subject was related to the common visits of the author to the outcrops in the area on many geological occasions in the past, including the field-courses with students of the Geological Faculty of the University of Warsaw during many years, which resulted in the gathering of observations, but also the collecting of numerous ammonites picked personally and donated by other persons (especially E. Głowniak, M. Machalski, U. Radwańska, A. Radwański, and A. Sochaczewski), especially from the large cement-works quarry at Małogoszcz. The study in common with Bronisław Matyja of the detailed section of this quarry, and the inspired discussions with him on many subjects of the Jurassic geology helped very much in preparation of the manuscript. The revision of the older collection of ammonites gathered by many years by the late J. Kutek and housed in the Museum of the Geological Faculty of the University of Warsaw was possible due to the help of M. Niechwedowicz, the curator of the collections. The author is grateful to the journal-referees: M. Machalski, G. Schweigert and J.K. Wright for valuable comments and suggestions. G. Pieńkowski and H. Wierzbowski are thanked for useful comments and discussion.

\section{REFERENCES}

ABBINK O., TARAGONA J., BRINKHUIS H., VISSCHER H., 2001 - Late Jurassic to earliest Cretaceous palaeoclimatic evolution of the southern North Sea. Global and Planetary Change, 30: 231-256.

ALEXANDROWICZ S.W., BARWICZ-PISKORZ W., 1974 Profile stratygraficzne górnej jury w obrzeżeniu Gór Świętokrzyskich. Część III - Góra Bukowa w Skórkowie koło Małogoszczy. Zeszyty Naukowe Akademii Górniczo-Hutniczej, Geologia, 19: 71-86.

ARKELL W.J. 1937 - Report on ammonites collected at Long Stanton, and on the age of the Ampthill Clay. In: Summary of Progress of the Geological Survey of Great Britain and the $\mathrm{Mu}-$ seum of Practical Geology for the year 1935, part II, V: 64-88. London.

ATROPS F., 1982 - La sous-familie des Ataxioceratinae (Ammonitina) dans le Kimméridgien inférieur du Sud-Est de la France. Systématique, évolution, chronostratigraphie des genres, Orthosphinctes et Ataxioceras. Documents des Laboratoires de Géologie de Lyon, 83: 1-463.

BARSKI M., 2012 - Dinoflagellate cysts from neptunian dykes in the Middle Jurassic of Poland - a stratigraphical approach. Review of Palaeobotany and Palynology, 169: 38-47.

BARWICZ-PISKORZ W., 1995 - Foraminiferal assemblages and stratigraphy of Upper Jurassic in Holy Cross Mountains district. Rozprawy Monografie, 21: 1-147 (in Polish). Wydaw. AGH.

BIRKELUND T., CALLOMON J.H., 1985 - The Kimmeridgian ammonite faunas of Milne Land, central East Greenland. Grønlands Geologiske Undersøgelse, 153: 1-56.

BIRKELUND T., CALLOMON J.H., CLAUSEN C.K., NØHR HANSEN H., SALINAS I.N., 1983 - The Lower Kimmeridgian Clay at Westbury, Wiltshire, England. Proceedings of the Geolgists' Association, 94, 4; 289-309.

BOULILA S., GALBRUN B., HINNOV L.A., COLLIN P.Y., 2008 - Orbital calibration of the Early Kimmeridgian (southeastern France): implications for geochronology and sequence stratigraphy. Terra Nova, 20, 6: 455-462.

BOULILA S., de RAFÉLIS M., , HINNOV L.A., GARDIN S., GALBRUN B., COLLIN P.Y., 2010 - Orbitally forced climate and sea-level changes in the Paleoceanic Tethyan domain (marl - limestone alternations, Lower Kimmeridgian, SE France). Palaeogeography, Palaeoclimatology, Palaeoecology, 292: 57-70.

CHUDZIKIEWICZ L., WIECZOREK J., 1985 - Bored and encrusted clasts in the Lower Kimmeridgian carbonates at Sobków (SW margin of the Holy Cross Mts., Poland). Annales Societatis Geologorum Poloniae, 55, 3/4: 295-306.

COLOMBIÉ C., STRASSER A., 2003 - Depositional sequences in the Kimmeridgian of the Vocontian Basin (France) controlled by carbonate export from shallow-water platforms. Geobios, 36: $675-683$. 
COMMENT G., LEFORT A., KOPPKA J., HANTZPERGUE P., 2015 - Le Kimméridgien d'Anjoie (Jura, Suisse); lithostratigraphie et biostratigraphie de la Formation de Reuchenette. Revue de Paléobiologie, Genève, 34, 2: 161-194.

DADLEZ R., MAREK S., POKORSKI J., 2000 - Geological map of Poland without Cainozoic deposits, 1:1000000. Państwowy Instytut Geologiczny, Warszawa.

DEMBOWSKA J., 1979 - Systematization of lithostratigraphy of the Upper Jurassic in northern and central Poland. Kwartalnik Geologiczny, 23, 3: 617-630 (in Polish with English summary).

DOHM B., 1925 - Ueber den oberen Jura von Zarnglaff i.P. und seine Ammonitenfauna. Abhandlungen des Geologischen Instituts der Universität Greifswald, 4 : 1-40.

ENAY R., 2000 - Une faune d'ammonites inédite du Kimméridgien inférieur à Molinges (Jura) et la limite Oxfordien-Kimméridgien dans le faisceau externe du Jura méridional. Géologie de la France, 4: 3-19.

ENAY R., HOWARTH M.K., 2019 - Systematic description of the Perisphinctoidea. Part L, revised, Volume 3B, Chapter 7. Treatise Online, 120: 1-184.

ENAY R., CONTINI D., BOULLIER A., 1988 - Le Séquanien type de Franche-Comté (Oxfordien supérieur): datations et correlations nouvelles, consequences sur la paléogéographie et l'évolution du Jura et regions voisines. Eclogae Geologicae Helvetiae, 81, 2: 295-363.

FÜRSICH F.T., SYKES R.M., 1977 - Palaeobiogeography of the European Boreal Realm during Oxfordian (Upper Jurassic) times: a quantitative approach. Neues Jahrbuch für Geologie und Paläontologie Abhandlungen, 155, 2: 137-161.

GARBOWSKA J., 1970 - Foraminiferal assemblages of the uppermost Oxfordian and Lower Kimmeridgian of the Wielun Upland and their stratigraphic importance. Acta Geologica Polonica, 20, 1: 33-89 (in Polish with English summary).

GEYER O.F., 1961 - Monographie der Perisphinctidae des unteren Unterkimeridgium (Weisser Jura $\gamma$, Badenerschichten) im süddeutschen Jura. Palaeontographica, 117A, 1-4: 1-157.

GŁOWNIAK E., KISELEV D.N., ROGOV M., WIERZBOWSKI A., WRIGHT J.K., 2010 - The Middle Oxfordian to lowermost Kimmeridgian ammonite succession at Mikhalenino (Kostroma District) of Russian Platform, and its stratigraphical and palaeobiogeographical importance. Volumina Jurassica, 8: 5-48.

GRUSZCZYŃSKI M., 1986 - Hardgrounds and ecological succession in the light of early diagenesis (Jurassic, Holy Cross Mts., Poland). Acta Palaeontologica Polonica, 31, 3/4:163-212.

GUTOWSKI J., 1992 - Górny oksford i kimeryd północno-wschodniego obrzeżenia Gór Świetokrzyskich, PhD Thesis, Faculty of Geology, University of Warsaw (unpublished).

GUTOWSKI J., 1998 - Oxfordian and Kimmeridgian of the northeastern margin of the Holy Cross Mountains, Central Poland. Geological Quarterly, 42, 1: 59-72.

GUTOWSKI J., 2006 - Field-trip B2 - Upper Jurassic shallowwater carbonate platform and open shelf facies. Introduction. In: Jurassic of Poland and adjacent Slovakian Carpathians. Field trip guidebook, $7^{\text {th }}$ International Congress on the Jurassic System, 6-18.09.2006, Kraków, Poland (eds. A.Wierzbowski et al.): 169-173. Polish Geological Institute, Warszawa.

GUTOWSKI J., WIERZBOWSKI A., ZLONKIEWICZ Z., 2006 Bukowa, large limestone quarry (Upper Oxfordian - lower- most Kimmeridgian). In: Jurassic of Poland and adjacent Slovakian Carpathians. Field trip guidebook, $7^{\text {th }}$ International Congress on the Jurassic System, 6-18.09.2006, Kraków, Poland (eds. A.Wierzbowski et al.): 188-190. Polish Geological Institute, Warszawa.

GYGI R., 1990 - The Oxfordian in northern Switzerland, Guidebook for the field trip to Swiss Jura of the Oxfordian Working group (International Subcommission on Jurassic Stratigraphy): 17-70. Basel.

GYGI R., 1995 - Datierung von Seichtwassersedimenten des Späten Jura in der Nordwestschweiz mit Ammoniten. Eclogae Geologicae Helvetiae, 88, 1:1-58.

GYGI R., 2000 - Integrated stratigraphy of the Oxfordian and Kimmeridgian (Late Jurassic) in northern Switzerland and adjacent southern Germany. Denkschriften der Schweizerischen Akademie der Naturwissenschaften, 104: 1-151.

GYGI R., 2003 - Perisphinctacean ammonites of the late Jurassic in northern Switzerland: a versatile tool to investigate the sedimentary geology of an epicontinental sea. Schweizerische Paläontologische Abhandlungen, 123: 1-232.

GYGI R., PERSOZ F., 1986 - Mineralostratigraphy, litho- and biostratigraphy in correlation of the Oxfordian (Late Jurassic) formations of the Swiss Jura range. Eclogae Geologicae Helvetiae, 79, 2: 385-454.

GYGI R., COE A.L., VAIL P.R., 1998 - Sequence stratigraphie of the Oxfordian and Kimmeridgian stages (Late Jurassic) in northern Switzerland. In: Mesozoic and Cenozoic Sequence Stratigraphy of European Basins, SEPM Special Publication, 60: $527-544$.

HAKENBERG M., 1978 - Albian-Cenomanian palaeotectonics and palaeogeography of the Miechów Depression, northern part. Studia Geologica Polonica, 58: 1-104 (in Polish with English summary).

HAKENBERG M., 1980 - Dependance of the thickness of Permian to Jurassic sediments in the Miechów Basin on major faults. Acta Geologica Polonica, 30, 4: 471-482.

HANTZPERGUE P., 1989 - Les ammonites kimméridgiennes du haut-fond d'Europe occidentale: biochronologie, systématique, évolution, paléobiogéographie. Centre National de la Recherche Scientifique. Paris: 1-425.

HANTZPERGUE P., 1991 - Différenciation paléobiogégraphique d'une faune d'ammonites dans l'horizon à Ardescia pseudolictor (zone à Cymodoce) du Kimméridgien nord-aquitain. Geobios, 24, 4: 423-433.

HANTZPERGUE P., 1995 - Faunal trends and sea-level changes: biogeographic patterns of Kimmeridgian ammonites on the Western European Shelf. Geologische Rundschau, 84: 245-254.

HARDENBOL J., THIERRY J., FARLEY M.B., JACQUIN T., de GRACIANSKY P.C., VAIL P.R., 1998 - Mesozoic and Cenozoic sequence chronostratigraphy framework of the European basins. Society for Sedimentary Geology, spec. publ., 60: 1-39.

JANK M., WETZEL A., MEYER C.A., 2006a - Late Jurassic sealevel fluctuations in NW Switzerland (Late Oxfordian to Late Kimmeridgian): closing the gap between the Boreal and Tethyan realm in Western Europe. Facies, 52: 487-519.

JANK M., MEYER C.A., WETZEL A., 2006b - Late Oxfordian to Late Kimmeridgian carbonate deposits of NW Switzerland (Swiss Jura): stratigraphical and palaeogeographical implica- 
tions in the transition area between the Paris Basin and the Tethys. Sedimentary Geology, 186: 237-263.

JANK M., WETZEL A., MEYER C.A., 2006c - A calibrated composite section for the Late Jurassic Reuchenette Formation in northwestern Switzerland (? Oxfordian, Kimmeridgian sensu gallico, Ajoie - Region). Eclogae Geologicae Helvetiae, 99: 175-191.

JURKIEWICZ J., KOWALCZEWSKI Z., WIERZBOWSKI A., 1969 - Geological cross-section through the Permo-Mesozoic deposits of the Nida Trough. Kwartalnik Geologiczny, 13, 3: 604-618 (in Polish with English summary).

KAŹMIERCZAK J., PSZCZÓŁKOWSKI A., 1968 - Sedimentary discontinuities in the Lower Kimmeridgian of the Holy Cross Mts. Acta Geologica Polonica, 18, 3: 587-612.

KRAJEWSKI M., OLCHOWY P., FELISIAK I., 2014 - Lower Kimmeridgian layer with bored and encrusted hiatus concretions (Upper Jurassic, Central Poland): implications for stratigraphy and basin evolution. Annales Societatis Geologorum Poloniae, 84, 2: 113-129.

KRAJEWSKI M., OLCHOWY P., FELISIAK I., 2016 - Late Jurassic facies architecture of the Złoczew Graben: implications for evolution of the tectonic-controlled northern peri-Tethys shelf (Upper Oxfordian - Lower Kimmeridgian). Facies, 62, 4: 3-19.

KRAJEWSKI M., OLCHOWY P., ZATOŃ M., BAJDA T., 2017 Kimmeridgian hardground - sequence boundary from the Mesozoic margin of the Holy Cross Mountains (central Poland): implications for the evolution of the northern Tethyan carbonate shelf. Facies, 63: 1-15.

KSIĄŻKIEWICZ M., SAMSONOWICZ J., 1953 - Zarys geologii Polski. Państwowe Wydawnictwa Naukowe, Warszawa.

KUTEK J., 1962a - Cherts and submarine slumps in the Lower Kimmeridgian limestones from the vicinity of Małogoszcz (Central Poland.). Acta Geologica Polonica, 12, 3: 377-391.

KUTEK J., 1962b - Palaeogeographic significance of ammonitic fauna of the Middle and Upper Malm in central Poland. Bulletin de l'Académie Polonaise des Sciences, Série des sciences géologiques et géographiques, 10, 2: 79-84.

KUTEK J., 1968 - The Kimmeridgian and uppermost Oxfordian in the SW margins of the Holy Cross Mts. (Central Poland). Part I. Stratigraphy. Acta Geologica Polonica, 18, 3: 494-586 (in Polish with English summary).

KUTEK J., 1969 - The Kimmeridgian and uppermost Oxfordian in the SW margins of the Holy Cross Mts. (Central Poland). Part II. Paleogeography. Acta Geologica Polonica, 19, 2: 221-321 (in Polish with English summary).

KUTEK J., 1994 - Jurassic tectonic events in south-eastern cratonic Poland. Acta Geologica Polonica, 44, 3/4:167-221.

KUTEK J., 1996 - The Nida depression as a part of the Polish Permo-Mesozoic rift basin. Prace Instytutu Geografii WSP w Kielcach, 1: 51-68 (in Polish with English summary).

KUTEK J., GŁAZEK J., 1972 - The Holy Cross area, central Poland in the Alpine cycle. Acta Geologica Polonica, 22, 4: 603652.

KUTEK J., RADWAŃSKI A., 1965 - Upper Jurassic onkolites of the Holy Cross Mts. (Central Poland). Bulletin de l'Académie Polonaise des Sciences, Série des sciences géologiques et géographiques, 13, 2: 155-160.
KUTEK J., RADWAŃSKI A., 1967 - Sedimentological problems of Lower Kimmeridgian onkolitic horizon at Celiny in the Holy Cross Mts. Rocznik Polskiego Towarzystwa Geologicznego, 37, 2: 267-272 (in Polish with English summary).

KUTEK J., WIERZBOWSKI A., BEDNAREK J., MATYJA B.A., ZAPAŚNIK T., 1977 - Z problematyki stratygraficznej osadów górnojurajskich Jury Polskiej. Przegląd Geologiczny, 25, 8/9: 438-445.

MACHALSKI M., 1993 - Ławice ostrygowe kimerydu obrzeżenia Gór Świetokrzyskich. Unpublished Ph. D. Thesis. Institute of Palaeobiology Polish Academy of Sciences.

MACHALSKI M., 1996 - Jurassic isopod in restricted environment. Acta Palaeontologica Polonica, 41, 3: 276.

MACHALSKI M., 1998 - Oyster life position and shell beds from the Upper Jurassic of Poland. Acta Palaeontologica Polonica, 43, 4: 609-634.

MALINOWSKA L., 1970 - Upper Jurassic. In: The stratigraphy of the Mesozoic in the margin of the Góry Świetokrzyskie. Prace Instytutu Geologicznego, 56: 135-184 (in Polish with English summary).

MATYJA B.A., 1977 - The Oxfordian in the south-western margin of the Holy Cross Mts. Acta Geologica Polonica, 27, 1: 41-64 (in Polish with English summary).

MATYJA B.A., 2009 - Development of the Mid-Polish Trough versus Late Jurassic evolution in the Carpathian Foredeep. Geological Quarterly, 53, 1: 49-62.

MATYJA B.A., 2011 - Płytkowodna platforma węglanowa późnej jury na południowo-zachodnim obrzeżeniu Gór Świętokrzyskich. In: Materiały konferencyjne Jurassica IX, Małogoszcz, 06-08.09.2011 (eds. B.A. Matyja et al.): 133-151. Wydział Geologii Uniwersytetu Warszawskiego.

MATYJA B.A., 2015 - Jurajska ewolucja północnego obrzeża Tetys. In: Ekstensja i inwersja powaryscyjskich basenów sedymentacyjnych. 84. Zjazd Naukowy Polskiego Towarzystwa Geologicznego, Chęciny 9-11.09.2015 (Ed. S. Skompski). Państwowy Instytut Geologiczny - PIB, Warszawa.

MATYJA B.A., WIERZBOWSKI A., 1995 - Biogeographic differentiation of the Oxfordian and Early Kimmeridgian ammonite faunas of Europe and its stratigraphic consequences. Acta Geologica Polonica, 45, 1/2: 1-8.

MATYJA B.A., WIERZBOWSKI A., 1996 - Sea-bottom relief and bathymetry of Late Jurassic sponge megafacies. Geo-Research Forum, 1/2: 333-340.

MATYJA B.A., WIERZBOWSKI A., 1998 - The stratigraphical and palaeogeographical importance of the Oxfordian and Lower Kimmeridgian succession in the Kcynia IG IV Borehole. Biuletyn Państwowego Instytutu Geologicznego, 382: 35-70 (in Polish with English summary).

MATYJA B.A., WIERZBOWSKI A., 2000 - Biostratigraphical correlations between the Subboreal Mutabilis Zone and the Submediterranean upper Hypselocyclum-Divisum zones of the Kimmeridgian: new data from northern Poland. Geo-Research Forum, 6: 129-136.

MATYJA B.A., WIERZBOWSKI A., 2002 - Boreal and Subboreal ammonites in the Submediterranean uppermost Oxfordian in the Bielawy section (northern Poland) and their correlation value. Acta Geologica Polonica, 52, 4: 411-421. 
MATYJA B.A., WIERZBOWSKI A., 2004 - Stratigraphy and facies development in the Upper Jurassic of the Kraków-Częstochowa Upland. In: Zróżnicowanie i przemiany środowiska przyrodniczo-kulturowego Wyżyny Krakowsko-Częstochowskiej (Ed. J. Partyka), 1: 13-26. Ojcowski Park Narodowy, Ojców (in Polish with English summary).

MATYJA B.A., WIERZBOWSKI A., 2006a - Introduction. Middle and Upper Jurassic. In: Jurassic of Poland and adjacent Slovakian Carpathians. Field trip guidebook, $7^{\text {th }}$ International Congress on the Jurassic System, 6-18.09.2006, Kraków, Poland (eds. A.Wierzbowski et al.): 130-131. Polish Geological Institute, Warszawa.

MATYJA B.A., WIERZBOWSKI A., 2006b - Julianka, coral colonization of the cyanobacteria-sponge bioherms at the turn of the Oxfordian and Kimmeridgian. Field trip guidebook, $7^{\text {th }}$ International Congress on the Jurassic System, 6-18.09.2006, Kraków, Poland (eds. A.Wierzbowski et al.): 203-204. Polish Geological Institute, Warszawa.

MATYJA B.A., WIERZBOWSKI A., 2014 - Upper Jurassic of the Tomaszów syncline, NW Mesozoic margin of the Holy Cross Mts. In: Jurajskie utwory synkliny tomaszowskiej. Jurassica XI, Przewodnik wycieczek terenowych, abstrakty i artykuły. Spała, 9-11.10.2014 (eds. A. Feldman-Olszewska, A. Wierzbowski): 9-20. Państwowy Instytut Geologiczny - PIB, Warszawa (in Polish with English summary).

MATYJA B.A., WIERZBOWSKI A., 2016 - Jura górna. In: Wody podziemne rejonu częstochowsko-zawierciańskiego ich występowanie, zagrożenia, degradacja i ochrona (Ed. A. Pacholewski): 18-26. Informator PSH, Państwowy Instytut Geologiczny - PIB Warszawa.

MATYJA B.A., GUTOWSKI J., WIERZBOWSKI A., 1989 - The open shelf - carbonate platform succession at the Oxfordian/ Kimmeridgian boundary in the SW margin of the Holy Cross Mts: stratigraphy, facies, and ecological implications. Acta Geologica Polonica, 39, 1-4: 29-48.

MATYJA B.A., WIERZBOWSKI A., RADWAŃSKA U., RADWAŃSKI A., 2006a - Małogoszcz, large quarry of cementworks (Lower and lowermost Upper Kimmeridgian). In: Jurassic of Poland and adjacent Slovakian Carpathians. Field trip guidebook, $7^{\text {th }}$ International Congress on the Jurassic System, 6-18.09.2006, Kraków, Poland (eds. A.Wierzbowski et al.): 190-198. Polish Geological Institute, Warszawa.

MATYJA B.A., WIERZBOWSKI A., WRIGHT J.K., 2006b - The Sub-Boreal/Boreal ammonite succession at the Oxfordian/ Kimmeridgian boundary at Flodigarry, Staffin Bay (Isle of Skye), Scotland. Transactions of the Royal Society of Edinburgh, Earth Sciences, 96: 387-405.

MESEZHNIKOV M.S., 1969 - Kimmeridgian ammonites. In: Fundamental section of the Upper Jurassic of Kheta River Basin (Ed. W.N. Sachs): 99-124. Nauka, Leningrad section, Leningrad (in Russian).

NIEMCZYCKA T., 1976a - Upper Jurassic rocks of the eastern Poland area (between the Vistula and the Bug rivers). Prace Instytutu Geologicznego, 77: 1-99 (in Polish with English summary).

NIEMCZYCKA T., 1976b - Lithostratigraphy of Upper Jurassic deposits in the Lublin-Radom area. Acta Geologica Polonica, 26, 4: 569-602 (in Polish with English summary).
NIEMCZYCKA T., 1981 - Jurassic cover in the Lublin Coal Basin. Kwartalnik Geologiczny, 25, 4: 675-686 (in Polish with English summary).

OLCHOWY P., KRAJEWSKI M., FELISIAK I., 2019 - Late Jurassic facies succession of the Kleszczów Graben area (southern border of the Łódź Depression, peri-Tethyan shelf, central Poland). Geological Quarterly, 63, 4: 657-682.

OPPEL A., 1863 - Ueber jurassische Cephalopoden. Palaeontologische Mittheilungen aus dem Museum des Koeniglich Bayerischen Staates, Stuttgart, 1, 3: 163-322.

PASTUSIAK F., 1987 - Rozwój sedymentacji i wykształcenie facjalne formacji bahamitowej Sobkowa. MSc. Thesis, unpublished. Institute of Geology, University of Warsaw.

PESZAT C., 1964 - The lithology of the Jurassic carbonate rocks (southeastern margin of the Holy Cross Mountains, Poland). Acta Geologica Polonica, 14, 1: 1-78 (in Polish with English summary).

PIEŃKOWSKI G., GUTOWSKI J., 2004 - Genesis of the Upper Oxfordian flints in Krzemionki Opatowskie (Poland). Tomy Jurajskie, 2: 29-36 (in Polish with English summary).

PSZCZÓŁKOWSKI A., 1970 - Application of aerial photographs in the research of the Kimmeridgian deposits in the SW margin of the Holy Cross Mts. Acta Geologica Polonica, 20, 2: $337-$ 363 (in Polish with English summary).

RADWAŃSKI A., 1960 - Submarine slides of epicontinental Upper Jurassic and Upper Cretaceous margins of the Holy Cross Mts. (Central Poland). Acta Geologica Polonica, 10, 2: 221246 (in Polish with English summary).

RADWAŃSKI A., 1995 - A unique "trilobite-like" fossil - the isopod Cyclosphaeroma malogostianum sp.n. from the Lower Kimmeridgian of the Holy Cross Mountains, Central Poland. Acta Geologica Polonica, 45, 1/2: 9-25.

RADWAŃSKI A., 2003 - Wapienie pasiaste dolnego kimerydu Gór Świetokrzyskich: przykłady prolapsji, diastazy oraz sytemu nor piętrowych. Tomy Jurajskie, 1: 71-76.

RONIEWICZ E., 1966 - Les Madréporaires du Jurassique supérieur de la bordure des Monts de Sainte-Croix, Pologne. Acta Palaeontologica Polonica, 11, 2: 157-268.

RONIEWICZ E., 2004 - Jurassic corals in Poland. Tomy Jurajskie (Volumina Jurassica), 2: 83-98 (in Polish).

RONIEWICZ E., RONIEWICZ P., 1968 - Hardground in the coraliferous Kimmeridgian deposits of the Holy Cross Mts. (Central Poland). Acta Geologica Polonica, 18, 2: 375-385 (in Polish with English summary).

RONIEWICZ E., RONIEWICZ P., 1971 - Upper Jurassic coral assemblages of the Central Polish Uplands. Acta Geologica Polonica, 21, 3: 399-423.

RONIEWICZ P., 1967 - Ripple-marks in the Upper Jurassic limestones of the Holy Cross Mts. Bulletin de l'Académie Polonaise des Sciences, Série des sciences géologiques et géographiques, 15, 2: 101-106.

RÓŻYCKI S.Z., 1953 - Górny dogger i dolny malm Jury KrakowskoCzęstochowskiej. Prace Instytutu Geologicznego, 17: 1-412.

SCHNEID T., 1939 - Über Raseniiden, Ringsteadiiden und Pictoniiden des nördlichen Frankenjura. Palaeontographica, 89, 4-6: 117-184.

SCHNEID T., 1940 - Über Raseniiden, Ringsteadiiden und Pictoniiden des nördlichen Frankenjura. Palaeontographica, 91, 3-6: 79-119. 
SCHNEID T., 1944 - Über Ataxioceratiden des nördlichen Frankenjura. Palaeontographica, 96: 1-43.

SCHWEIGERT G., CALLOMON J.H., 1997 - Der bauhini-Faunenhorizont und seine Bedeutung für die Korrelation zwischen tethyalem und subborealem Oberjura. Stuttgarter Beiträge zur Naturkunde, Serie B (Geologie und Paläontologie), 247: 1-69.

SEILACHER A., MATYJA B.A., WIERZBOWSKI A., 1985 Oyster beds; morphologic response to changing substrate conditions. In: Lecture Notes in Earth Sciences, 1. Sedimentary and evolutionary cycles (Ed. G.E. Friedman): 421-435. Springer, Berlin.

SPATH L.F., 1935 - The Upper Jurassic invertebrate faunas of Cape Leslie, Milne Land. I. Oxfordian and Lower Kimmeridgian. Meddelelser on Grønland, 99, 2: 1-78.

ŚWIDZIŃSKI H., 1935 - Equisee géologique des environs de Przedbórz sur la Pilica. Sprawozdania Państwowego Instytutu Geologicznego, 8, 3: 1-25 (in Polish with French summary).

ŚWIDZIŃSKI H., 1962 - Some cross-sections through the Upper Jurassic of the south-western slope of the Holy Cross Mts. Przeglad Geologiczny, 10, 9: 441-448 (in Polish with English summary).

VALEČKA J., 2019 - Jurassic pebbles in the Cretaceous sandstones of the Bohemian Basin as a possible tool for reconstruction of the Late Jurassic and Late Cretaceous palaeogeography. Volumina Jurassica, 17: 17-38.

VICKERS M.L., FERNANDEZ A., HESSELBO S.P., PRICE G.D., BERNASCONI S.M., LODE S., ULLMANN C.V., THIBAULT N., HOUGAARD J.W., KORTE C., 2020 - Unravelling Middle to Late Jurassic palaeoceanographic and palaeoclimatic signals in the Hebrides Basin using belemnite clumped isotope thermometry. Earth and Planetary Science Letters, 546: $1-10$.

WEGELE L., 1929 - Stratigraphische und faunistische Untersuchungen im Oberoxford und Unterkimmeridgium Mittelfrankens. I. Stratigraphischer Teil, Palaeontographica, 71, 4-6: 117-210; II. Palaeontologischer Teil, Palaeontographica, 72, 1-6: 1-94.

WIERZBOWSKI A., 1961 - Szkic geologiczny okolic Dobromierza i Pratkowic nad Pilicą. MSc. Thesis, unpublished. Faculty of Geology, University of Warsaw.

WIERZBOWSKI A., 1966 - Górny oksford i dolny kimeryd Wyżyny Wieluńskiej. Acta Geologica Polonica, 16, 2: 127-200.

WIERZBOWSKI A., 1970 - Some Upper Jurassic ammonites of the genus Ringsteadia Salfeld, 1913, from Central Poland. Acta Geologica Polonica, 20, 2: 269-285.

WIERZBOWSKI A., 2017a - The Lower Kimmeridgian of the Wieluń Upland and adjoining regions in central Poland: lithostratigraphy, ammonite stratigraphy (upper Planula to Divisum zones), palaeogeography and climate-controlled cycles. Volumina Jurassica, 15: 41-120.

WIERZBOWSKI A., 2017b - Evolution and palaeogeography of the ammonite family Aulacostephanidae Spath, 1924 during Late Oxfordian and Early Kimmeridgian in Europe. In: Jurassic System of Russia: problems of stratigraphy and palaeogeography (eds. V.A. Zakharov et al.): 255-258. Seventh AllRussian Meeting, Moscow, September 18-22, 2017. Moscow.
WIERZBOWSKI A., GŁOWNIAK E., 2018 - The Early Kimmeridgian succession at Kodrąb (Radomsko elevation, central Poland) and its palaeogeographical and palaeotectonic implications. Geological Quarterly, 62, 3: 509-521.

WIERZBOWSKI A., MATYJA B.A., 2014 - Ammonite biostratigraphy in the Polish Jura sections (central Poland) as a clue for recognition of the uniform base of the Kimmeridgian Stage. Volumina Jurassica, 12, 1: 45-98.

WIERZBOWSKI A., SMELROR M., 2020 - The Bajocian to Kimmeridgian (Middle to Upper Jurassic) ammonite succession at Sentralbanken High (core 7533/3-U-1), Barents Sea, and its stratigraphical and palaeobiogeographical significance. Volumina Jurassica, 18, 1: 1-22.

WIERZBOWSKI A., GŁOWNIAK E., PIETRAS K., 2010 - Ammonites and ammonite stratigraphy of the Bimammatum Zone and lowermost Planula Zone (Submediterranean Upper Oxfordian) at Bobrowniki and Raciszyn in the Wielun Upland, central Poland. Volumina Jurassica, 8: 49-102.

WIERZBOWSKI A., SMOLEŃ J., IWAŃCZUK J., 2015 - The Oxfordian and Lower Kimmeridgian of the Peri-Baltic Syneclise (north-eastern Poland): stratigraphy, ammonites, microfossils (foraminifers, radiolarians), facies and palaeogeographic implications. Neues Jahrbuch für Geologie und Paläontologie Abhandlungen, 277, 1; 63-104.

WIERZBOWSKI A., ATROPS F., GRABOWSKI J., HOUNSLOW M.W., MATYJA B.A., OLÓRIZ F., PAGE K.N., PARENT H., ROGOV M.A., SCHWEGERT G., VILLASEÑOR A.B., WIERZBOWSKI H., WRIGHT J.W., 2016 Towards a consistent Oxfordian/Kimmeridgian global boundary: current state of knowledge. Volumina Jurassica, 14: 15-50.

WIERZBOWSKI A., MATYJA B.A., WRIGHT J.K., 2018 - Notes on evolution of the ammonite families Aulacostephanidae and Cardioceratidae and the stratigraphy of the uppermost Oxfordian and lowermost Kimmeridgian in the Staffin Bay sections (Isle of Skye, Northern Scotland). Volumina Jurassica, 16: 27 50 .

WIERZBOWSKI H., 2019 - Palaeoenvironmental changes recorded in the oxygen and carbon isotope composition of Kimmeridgian (Upper Jurassic) carbonates from central Poland. Geological Quarterly, 63, 2: 359-374.

WIERZBOWSKI H., BAJNAI D., WACKER U., ROGOV M.A., FIEBIG J., TESAKOVA E.M., 2018 - Clumped isotope record of salinity variations in the Subboreal Province at the MiddleLate Jurassic transition. Global and Planetary Change, 167: $172-189$.

WRIGHT J.K., 2010 - The Aulacostephanidae (Ammonoidea) of the Oxfordian/Kimmeridgian boundary beds (Upper Jurassic) of southern England. Palaeontology, 53, 1: 11-52.

ZAKHAROV V., BAUDIN F., DZYUBA O.S., DAUX V., ZVEREV K.V., RENARD M., 2005 - Istopic and faunal record of high palaeotemperatures in the Kimmeridgian of the Subpolar Urals. Geologiya i Geofizika, 46, 1: 3-20 (in Russian).

ZŁONKIEWICZ Z., 2009 - The Callovian and Upper Jurassic section in the Nida Trough. Przeglad Geologiczny, 57, 6: 521-530 (in Polish). 
Plates 


\section{PLATE 1}

Fig. 1. Orthosphinctes (Lithacosphinctes) aff. stromeri (Wegele) $=[$ Lithacoceras (L.) evolutum (Quenstedt) in: Kutek (1968, pl. 3)]; the preserved fragment of outer whorl is the body chamber; Rogalów, Rogalów Limestone Mbr., Małogoszcz Oolite Fm., Platynota Zone; MWG UW ZI/100/38 




Andrzej WIERZBOWSKI - The Kimmeridgian of the south-western margin of the Holy Cross Mts., central Poland: stratigraphy and facies development. Part I. From deep-neritic sponge megafacies to shallow water carbonates 


\section{PLATE 2}

Fig. 1. Orthosphinctes (Lithacosphinctes) gidoni Atrops; phragmocone with initial part of the body chamber, giant specimen without outer whorl preserved; Bukowa quarry, Leśnica Limestone Mbr., Bukowa Fm., Platynota Zone; MWG UW ZI/100/30 


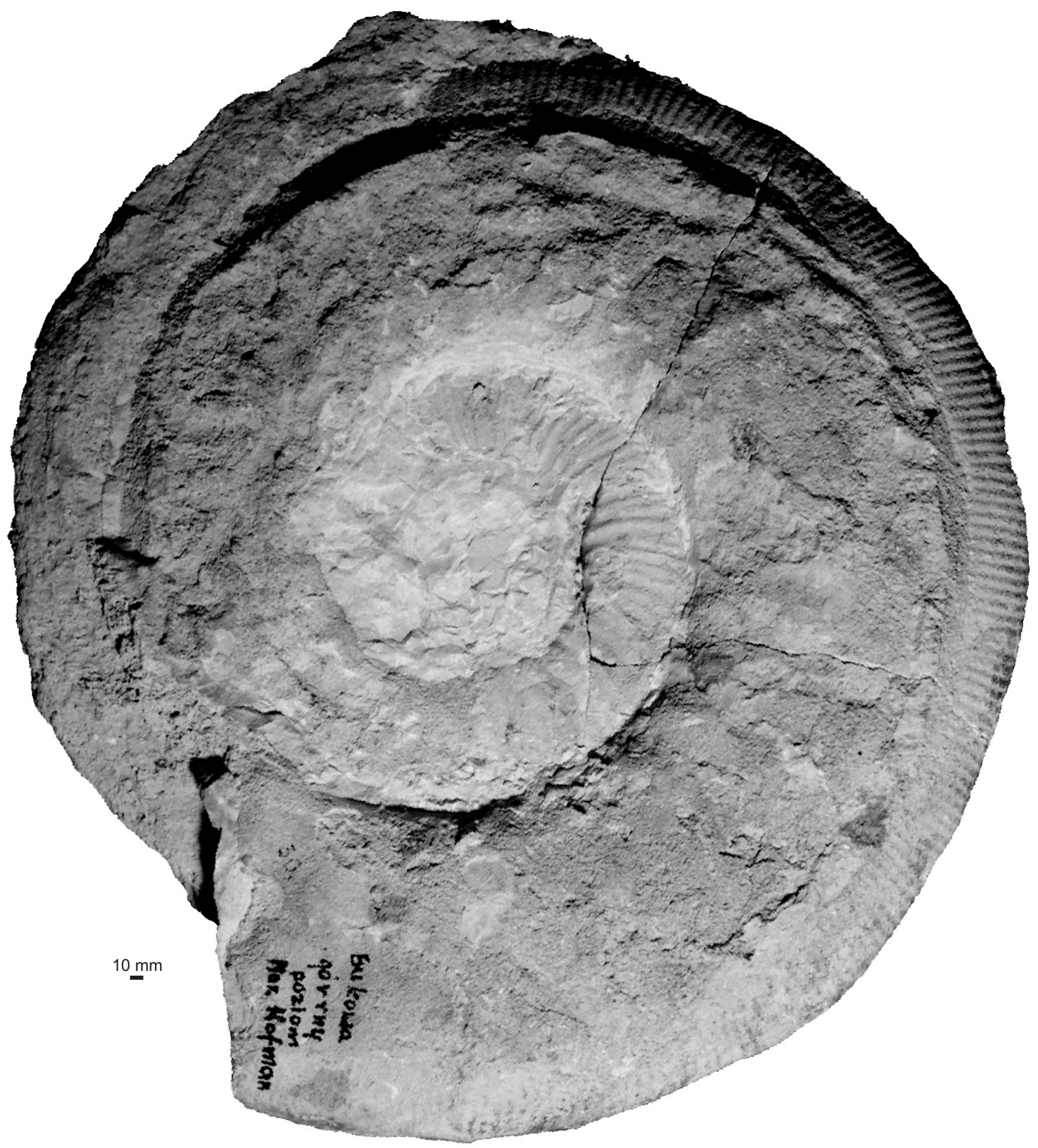

Andrzej WIERZBOWSKI - The Kimmeridgian of the south-western margin of the Holy Cross Mts., central Poland: stratigraphy and facies development. Part I. From deep-neritic sponge megafacies to shallow water carbonates 


\section{PLATE 3}

Fig. 1. Orthosphinctes (Orthosphinctes) polygyratus (Reinecke); phragmocone/body chamber boundary is arrowed; Bukowa quarry, Leśnica Limestone Mbr., Bukowa Fm., Platynota Zone; MWG UW ZI/100/39

Fig. 2. Ataxioceras (Schneidia) lussasense Atrops; phragmocone/body chamber boundary is arrowed; Małogoszcz cement-works quarry, Sobków Oolite Mbr., Małogoszcz Oolite Fm., lussasense horizon, Hippolytense Subzone, Hypselocyclum Zone; MWG UW ZI/100/33

Fig. 3A, B.Ataxioceras (Parataxioceras) sp.; fragments representing separate sides of the same specimen, phragmocone; Kościołek Hill at Leśnica, Celiny Onkolite Bd., Małogoszcz Oolite Fm., Hippolytense Subzone, Hypselocyclum Zone; MWG UW ZI/100/35

Fig. 4. Ataxioceras (Parataxioceras) cf. hippolytense Atrops; phragmocone/body chamber boundary is arrowed; Sobków quarry, Sobków Oolite Mbr., Małogoszcz Oolite Fm., Hippolytense Subzone, Hypselocyclum Zone; MWG UW ZI/100/34 

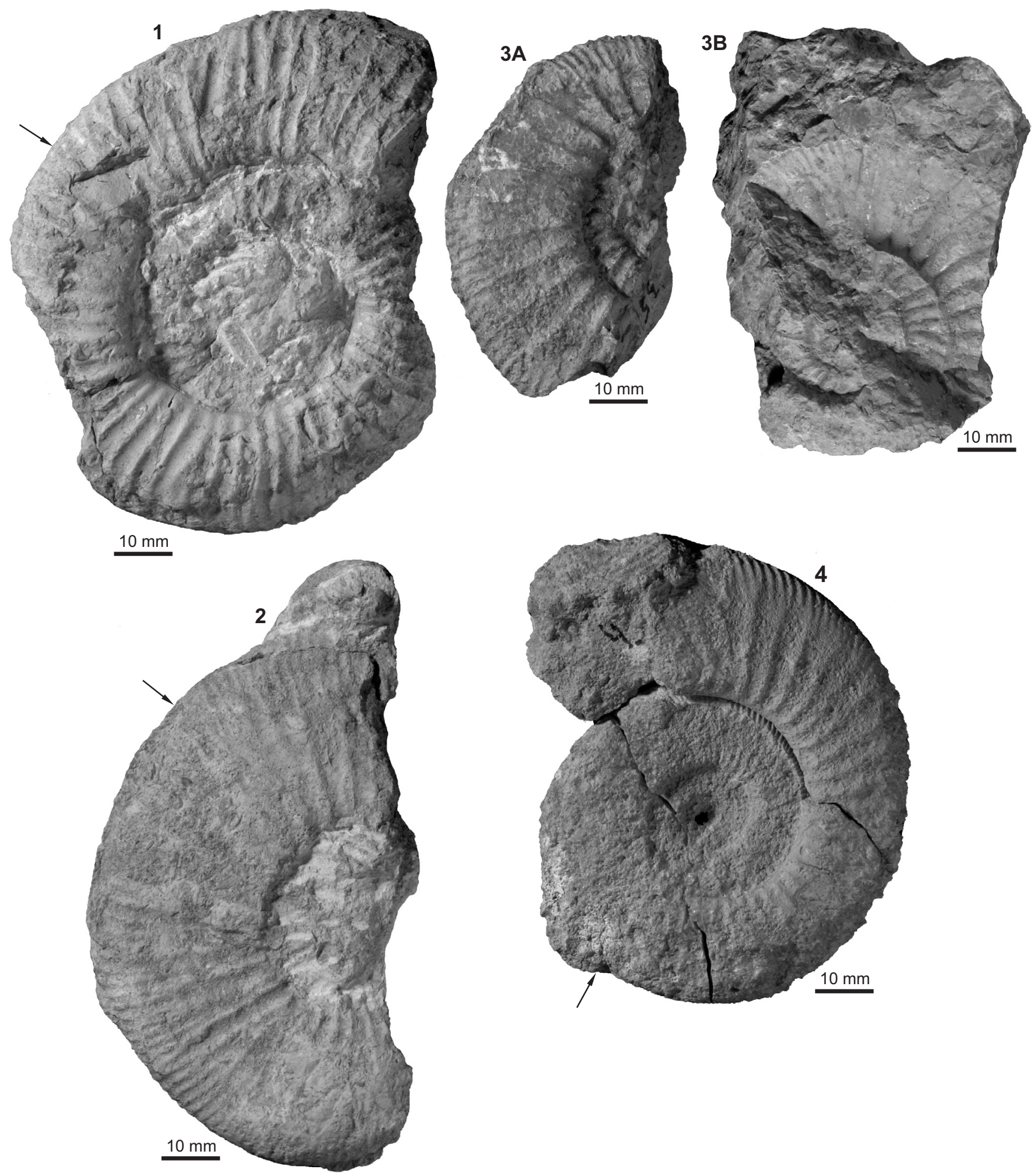

Andrzej WIERZBOWSKI - The Kimmeridgian of the south-western margin of the Holy Cross Mts., central Poland: stratigraphy and facies development. Part I. From deep-neritic sponge megafacies to shallow water carbonates 


\section{PLATE 4}

Fig. 1. Pictonia (Pomerania) dohmi (Arkell) $=[$ Pomerania (P. ) dohmi Arkell in: Kutek (1968, pl. 9)]; phragmocone/ body chamber boundary is arrowed; Krzyżowa Góra at Małogoszcz, Leśnica Limestone Mbr., Bukowa Fm., Platynota Zone; MWG UW ZI/100/5 




Andrzej WIERZBOWSKI - The Kimmeridgian of the south-western margin of the Holy Cross Mts., central Poland: stratigraphy and facies development. Part I. From deep-neritic sponge megafacies to shallow water carbonates 


\section{PLATE 5}

Fig. 1. Pictonia (Pomerania) cf. dohmi (Arkell); phragmocone; Rogalów, Rogalów Limestone Mbr., Małogoszcz Oolite Fm., Platynota Zone; MWG UW ZI/100/23

Fig. 2. Pachypictonia cf. perornatula Schneid; the last whorl possibly represents the body chamber; Sobków quarry, Sobków Oolite Mbr., Hippolytense Subzone, Hypselocyclum Zone; MWG UW ZI/100/29 


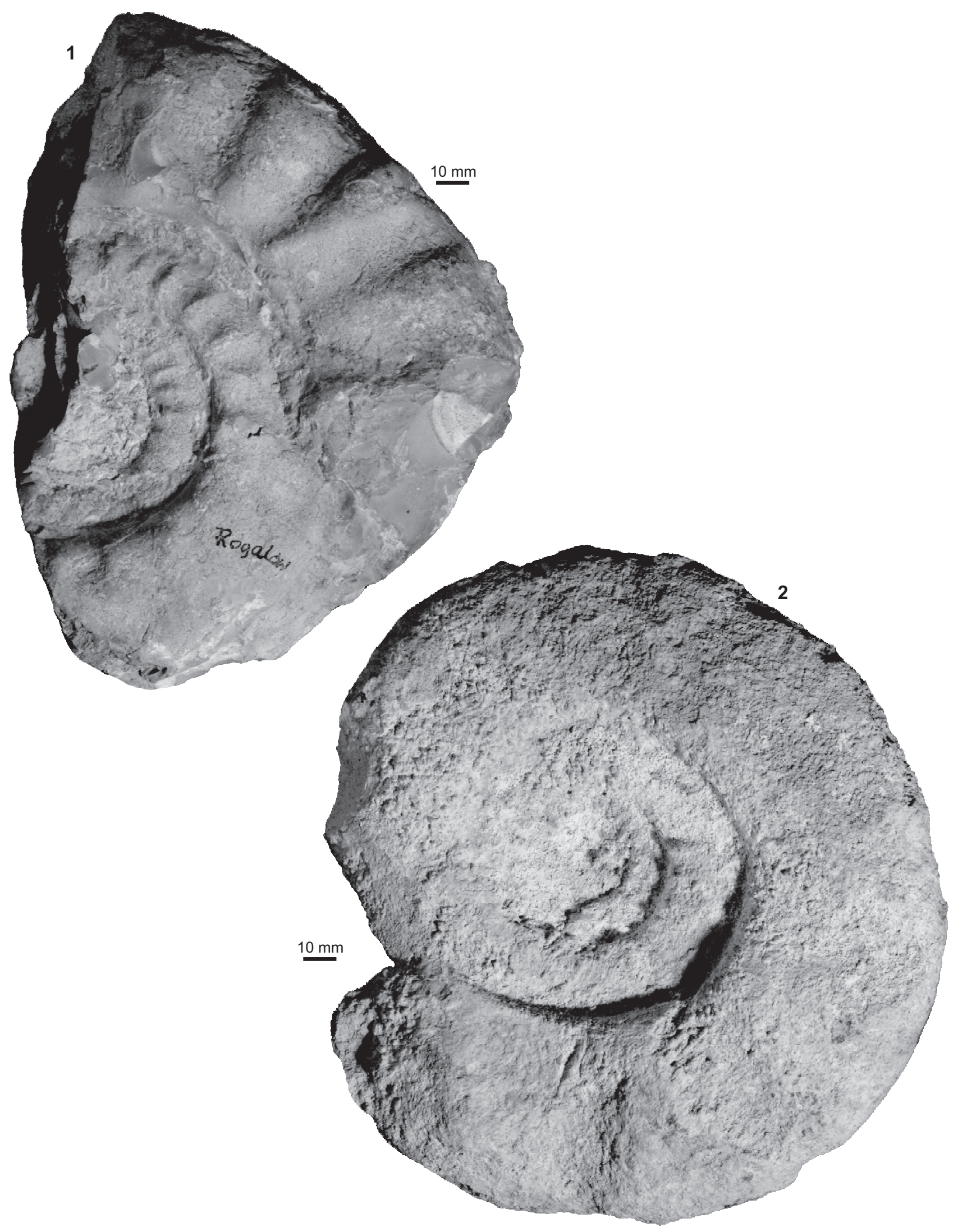

Andrzej WIERZBOWSKI - The Kimmeridgian of the south-western margin of the Holy Cross Mts., central Poland: stratigraphy and facies development. Part I. From deep-neritic sponge megafacies to shallow water carbonates 


\section{PLATE 6}

Fig. 1. Rasenia inconstans Spath $=$ [Rasenia (Eurasenia) pendula Schneid in: Kutek (1968, pl. 11)]; phragmocone/ body chamber boundary is arrowed; Rogalów, Rogalów Limestone Mbr., Małogoszcz Oolite Fm., Platynota Zone; MWG UW ZI/100/17 


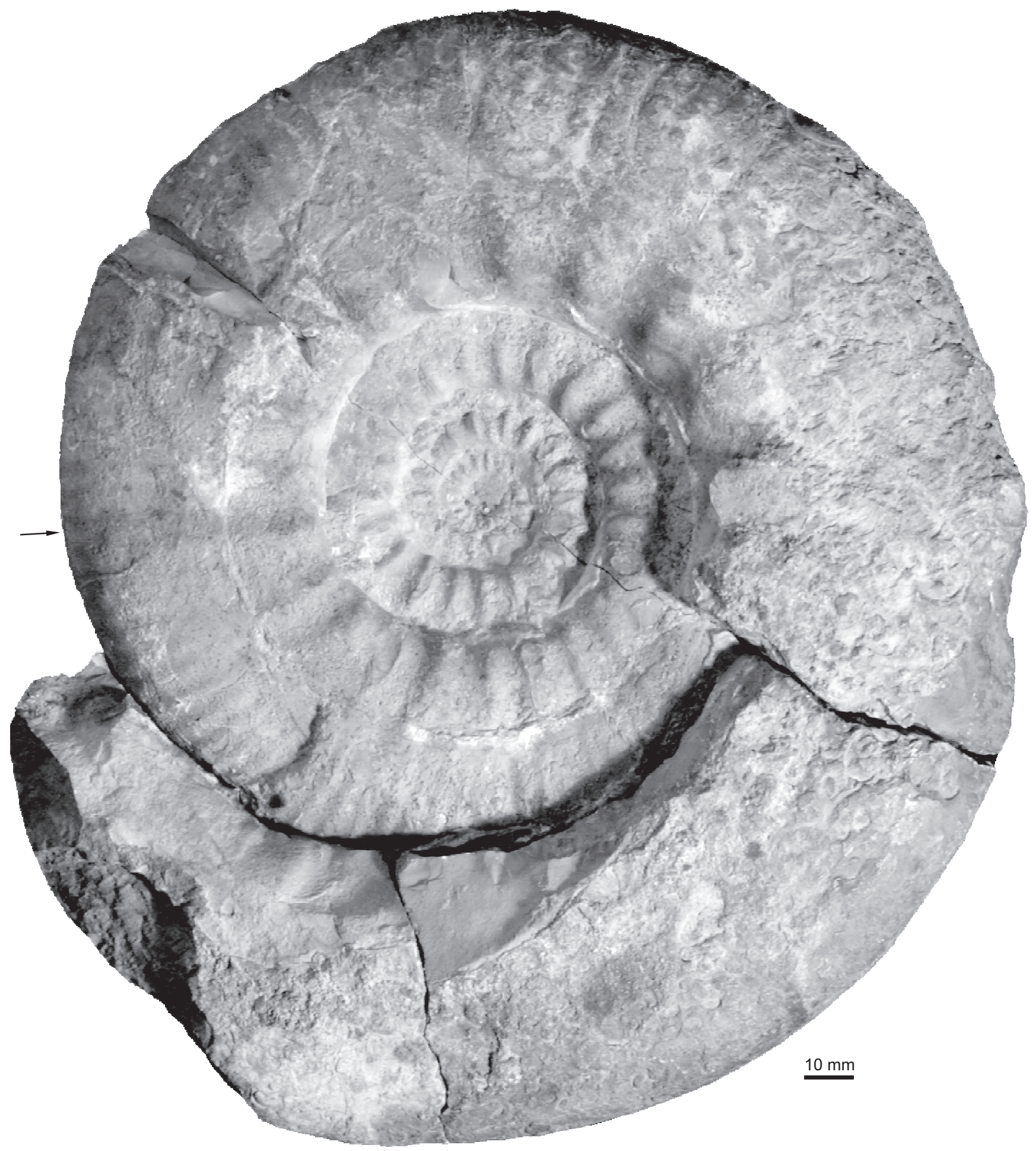

Andrzej WIERZBOWSKI - The Kimmeridgian of the south-western margin of the Holy Cross Mts., central Poland: stratigraphy and facies development. Part I. From deep-neritic sponge megafacies to shallow water carbonates 


\section{PLATE 7}

Fig. 1. Pachypictonia (?) cf. trifurcata (Reinecke); phragmocone; Sobków quarry, Sobków Oolite Mbr., Małogoszcz Oolite Fm; Hippolytense Subzone, Hypselocyclum Zone; MWG UW ZI/100/27

Fig. 2. $\quad$ Pachypictonia (?) cf. trifurcata (Reinecke); the last whorl at least partly represents the body chamber; Sobków quarry, Sobków Oolite Mbr., Małogoszcz Oolite Fm., Hippolytense Subzone, Hypselocyclum Zone; MWG UW $\mathrm{ZI} / 100 / 28$ 




Andrzej WIERZBOWSKI - The Kimmeridgian of the south-western margin of the Holy Cross Mts., central Poland: stratigraphy and facies development. Part I. From deep-neritic sponge megafacies to shallow water carbonates 


\section{PLATE 8}

Fig. 1. Involuticeras involutum (Quenstedt); phragmocone/body chamber boundary is arrowed; Sobków quarry, Sobków Oolite Mbr., Małogoszcz Oolite Fm ., Hippolytense Subzone, Hypselocyclum Zone; MWG UW $\mathrm{ZI} / 100 / 20$

Fig. 2. Involuticeras limbatum (Schneid); phragmocone/body chamber boundary is arrowed; Małogoszcz cementworks quarry, Celiny Onkolite Bd., Małogoszcz Oolite Fm., Hippolytense Subzone, Hypselocyclum Zone; MWG UW ZI/100/21 


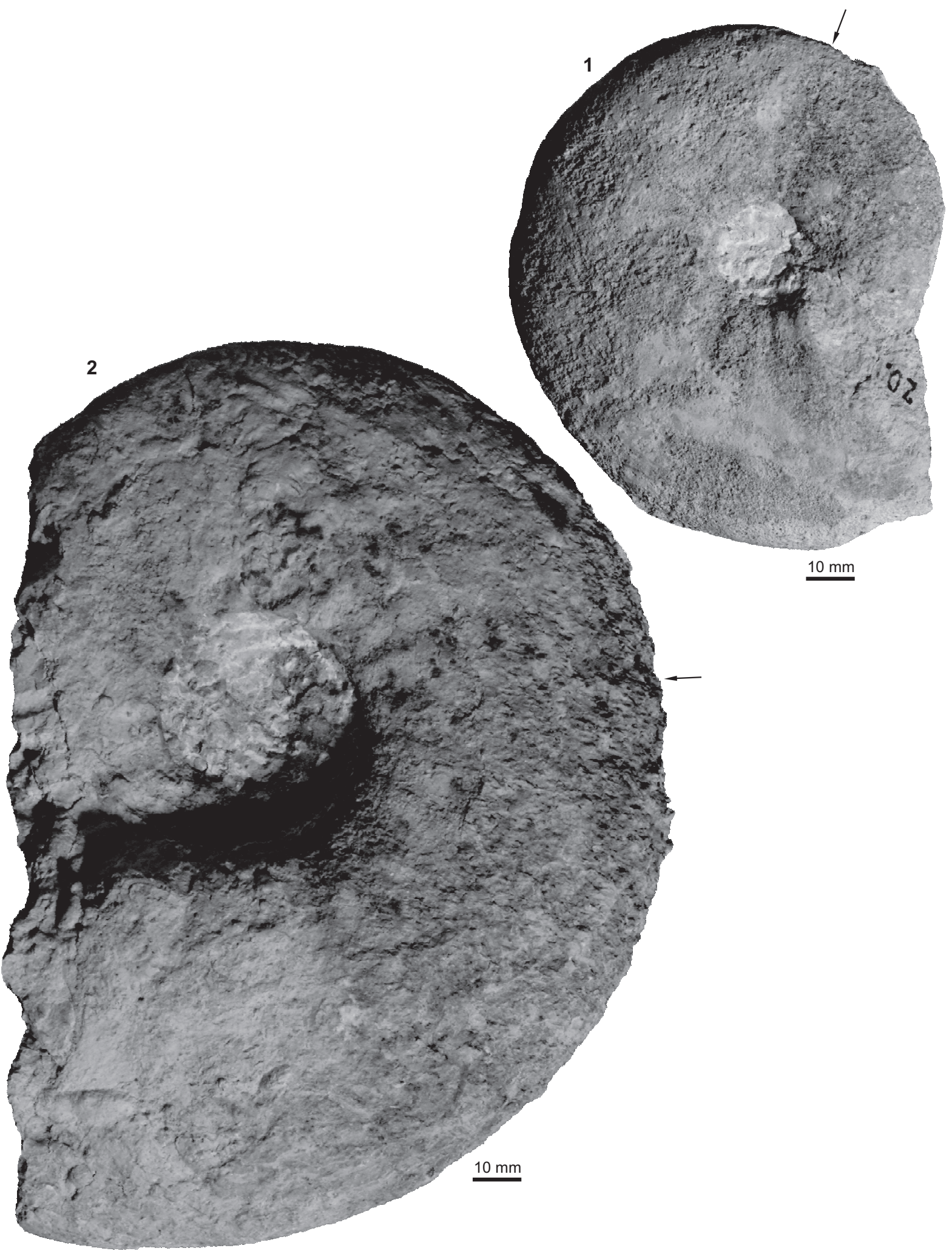

Andrzej WIERZBOWSKI - The Kimmeridgian of the south-western margin of the Holy Cross Mts., central Poland: stratigraphy and facies development. Part I. From deep-neritic sponge megafacies to shallow water carbonates 


\section{PLATE 9}

Fig. 1. Involuticeras limbatum (Schneid); the preserved fragment of outer whorl is the body chamber; Kościółek Hill at Leśnica, Sobków Oolite Mbr., Małogoszcz Oolite Fm., Hippolytense Subzone, Hypselocyclum Zone; MWG UW ZI/100/6 


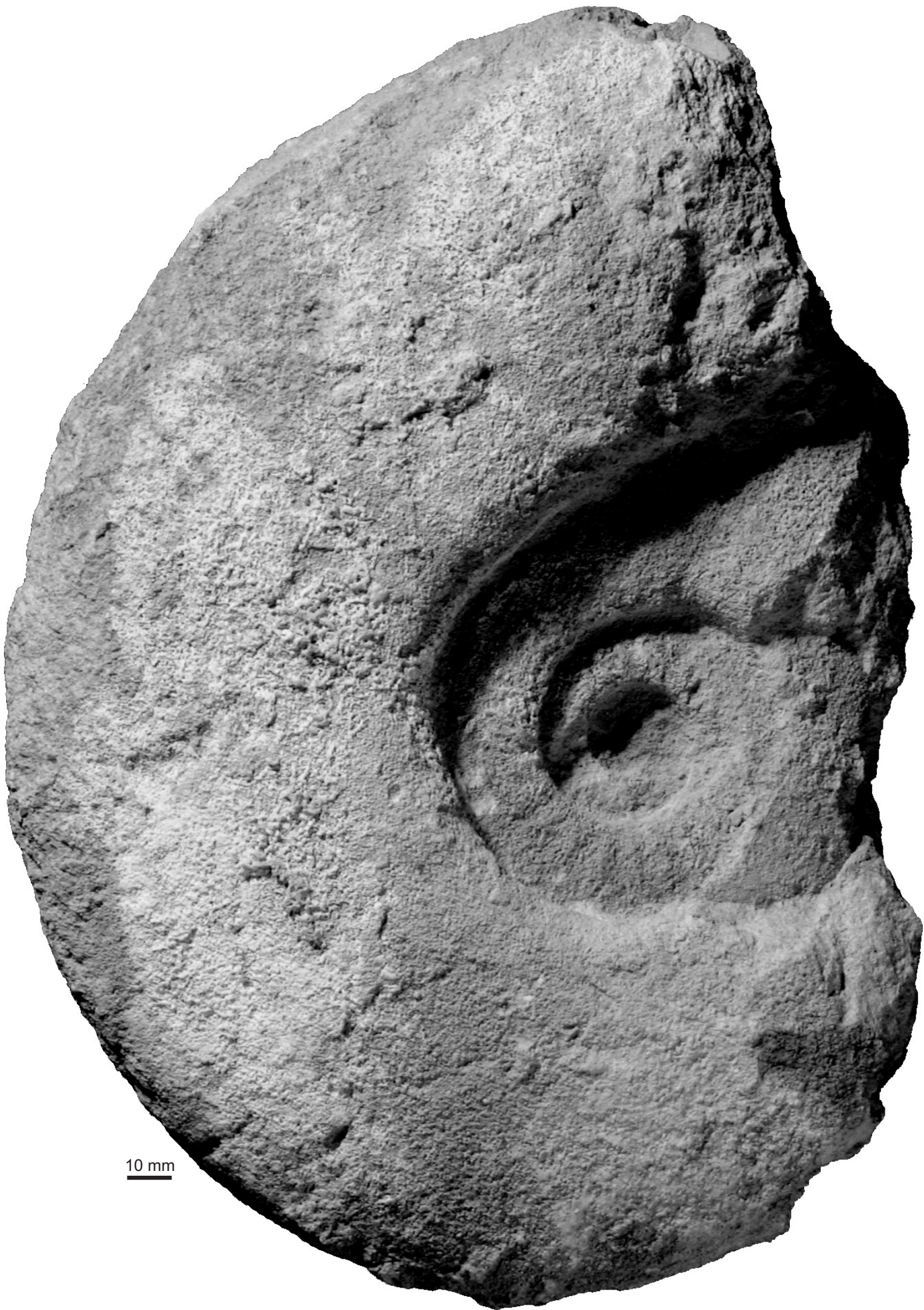

Andrzej WIERZBOWSKI - The Kimmeridgian of the south-western margin of the Holy Cross Mts., central Poland: stratigraphy and facies development. Part I. From deep-neritic sponge megafacies to shallow water carbonates 


\section{DESCRIPTION OF THE NEWLY ESTABLISHED FORMAL LITHOSTRATIGRAPHIC UNITS}

\section{PILICA FORMATION (MATYJA, WIERZBOWSKI, 2004)}

\author{
Siedlce Limestone Member (Matyja et al., 1989) \\ Wolica Bed \\ (herein established)
}

Name: After Wolica village where along with the neighboring Siedlce village in the south-western margin of the Holy Cross Mountains the deposits of the unit are exposed in the quarries (Polish name: warstwa $z$ Wolicy).

Type section: Wolica-Siedlce quarry section (Matyja, 1977).

Thickness: About 15 meters in the Wolica-Siedlce section.

Lithology: Three distinct marly layers (lower of $1.50 \mathrm{~m}$, middle $-0.35 \mathrm{~m}$, upper $-1.05 \mathrm{~m}$ in thickness), occurring in the 15-meter thick succession of micritic limestones, which split into thin flags, with poor benthic fauna. Marly deposits are dark blue (yellow-rusty when weathered), some fragments of echinoderms and quartz grains of sand-size are encountered (Matyja, 1977). A single sample from a marly layer at Wolica presented by Peszat (1964, fig. 7) indicates it comprises marly limestone showing $47.59 \% \mathrm{CaO}$.

Boundaries: Lower and upper boundaries correspond to the base and top of the lower, and upper marly layers, respectively. The bed in typical development occurs in the bedded limestones of the Siedlce Limestone Member from about 190 to about $205 \mathrm{~m}$ above the base of the Oxfordian (Matyja, 1977), and about 40-55 $\mathrm{m}$ above the base of the member, in the Wolica-Siedlce section (Matyja et al., 1989; see also Fig. 3, herein).

Geological age: Near the boundary between the Hypselum Zone and the Bimammatum Zone. Because this boundary corresponds to the base of the Kimmeridgian Stage as interpreted according to the proposal of International Subcommission on Jurassic Stratigraphy (see Wierzbowski A. et al., 2016, 2018), the Wolica Bed marks the level in the Upper Jurassic succession of the south-western margin of the Holy Cross Mts. in close proximity to the Oxfordian/ Kimmeridgian boundary.

Distribution: South-western margin of the Holy Cross Mts.

Equivalents: The marly layers of the Wolica Bed are recognized in the massive limestones of the Częstochowa
Sponge Limestone Formation in the south-western margin of the Holy Cross Mts. (Matyja, 1977). The marly layers occurring in the bedded limestones of the Częstochowa Sponge Limestone Formation in the Wielun Upland near the boundary of the Oxfordian and Kimmeridgian, like those at Bobrowniki (Wierzbowski, Matyja, 2014, figs. 2, 4, beds E, C; Wierzbowski et al., 2016, figs. 6, 9), possibly correspond to the marly layers of the Wolica Bed.

\section{BUKOWA FORMATION (herein established)}

Name: after Bukowa quarry at Bukowa village near Skorków village in the south-western margin of the Holy Cross Mts. (Polish name: formacja z Bukowej).

Type area and type section: South-western margin of the Holy Cross Mts., where the deposits of the formation crop out from Gruszczyn to Żerniki and Sobków (see Kutek, 1968, tab. 2; Pszczółkowski, 1970, fig. 3). The type section is that of Bukowa quarry described in detail by Matyja (2011, fig. 3; see also Gutowski et al., 2006), but fragments of it additionally were described by Roniewicz and Roniewicz (1971, fig. 5 - lower and upper parts), Roniewicz (1967, fig. 1, upper part), and Roniewicz (2004, appendix lower and middle parts).

Subdivision: The formation is subdivided into three members: the Piekielnica Coral Limestone Member, and the Leśnica Limestone Member - as formally distinguished herein, and the Góry Marl Member as distinguished by Wierzbowski (2017a) in the Wielun Upland which corresponds to the "lowermost marly horizon" of Kutek (1968). Additionally in the lowermost part of the Piekielnica Coral Limestone Member there is recognized informally a "basal unit" (Fig. 4) which should be distinguished in the future as a formal unit, possibly of bed (or even member) rank.

Thickness: about $60-75$ meters as calculated from sections given by Kutek (1968, tab. 2) and Pszczółkowski (1970, fig. 3). Thickness of the formation in the Bukowa quarry section is about 55-60 meters.

Lithology: chalky limestones with corals, grainstones (oolitic limestones, organodetrital limestones), micritic limestones and marls; the most diversified lithologies are observed in the lowermost part of the Piekielnica Coral 
Limestone Member (i.e. in the "basal unit") and in the Leśnica Limestone Member.

Boundaries: The lower boundary is marked by the prominent discontinuity surface widely distributed in the south-western margin of the Holy Cross Mts. and placed at the top of the Siedlce Limestone Member of the Pilica Formation (see Kaźmierczak, Pszczółkowski, 1968, fig. 2 - between units 1 and 2; Matyja et al., 1989, figs. 3, 4; Gutowski et al., 2006, fig. B2.28, contact between units 1 and 2); this surface marks also the base of the "basal unit" of the Piekielnica Coral Limestone Member (see above, $c f$. also Pszczółkowski, 1970, fig. 3). This boundary corresponds approximately to that between the "sub-reef complex" (I) and the "great-reef complex" (II) in the lithostratigraphic subdivision in the south-western margin by Świdziński (1962). The upper boundary of the Bukowa Formation is marked at the top of the Góry Marl Member ("lowermost marly horizon") placed at another important discontinuity surface marking the base of the Małogoszcz Oolite Formation (see below).

Geological age: Lower Kimmeridgian (uppermost part of the Planula Zone to middle part of the Platynota Zone).

Distribution and equivalents: South-western margin of the Holy Cross Mts. The formation can be recognized also in the north-western margin of the Holy Cross Mts., where it includes a lower part of the "oolitic" formation - the "lower" and the "upper Kurnędz limestone" members $\left(\mathrm{D}_{1}\right.$ and $\left.\mathrm{D}_{2}\right)$ as distinguished by Matyja and Wierzbowski (2014, fig. 2). It also occurs at the northern margin of the Wielun Upland and the adjacent Szczerców-Bełchatów region, where it includes the "unit A" representing a lower part of the "oolitic" formation as recognized by Wierzbowski (2017a, figs. 4-6). Possibly to this unit belong also the youngest Upper Jurassic limestones with corals cropped out in the Częstochowa Upland between Julianka and Dzibice (see: Roniewicz, Roniewicz, 1971; Matyja, Wierzbowski, 1996; Roniewicz, 2004; Matyja, Wierzbowski, 2006b).

The newly distinguished Bukowa Formation corresponds generally to a lower part of the "oolitic" (IV) formation of Dembowska (1979). The "oolitic" formation was characterized by highly diversified lithologies represented by oolitic limestones and organodetrital limestones, along with coral limestones and micritic limestones in changing amount in the succession. The formation yielded an abundant fauna of hermatypic corals, gastropods (nerineids), and bivalves - as seen in its strict equivalent - the Bełżyce Formation in the cores of the Lublin area (Niemczycka, 1976b; $c f$. Dembowska, 1979). Dembowska (1979) recognized also the "coral" (III) formation lying directly below the "oolitic" formation, but showing a restricted distribution, mostly confined to eastern Poland where it was recognized in the cores. The main difference between the "oolitic" formation and the "coral" formation was the occurrence of oolitic limestone bodies in the former, because chalky limestones with corals, gastropods (nerineids) and bivalves (diceratids, oysters) occurred commonly in both of them ( $c f$. Matyja, Wierzbowski, 2014). Such an interpretation of the "oolitic" formation resulted, however, in its very unclear definition, and obliterated in fact the existing differences in the succession (in the occurrence and dominance of different type of rocks - from the chalky limestones with corals, the oolitic limestones, the micritic limestones and marls). Thus, the "oolitic" formation as originally proposed by Dembowska (1979) appeared rather a "super-formation" which lumped "real" formations and members, differing markedly in their lithological character and distribution. This is the reason for recognition of the newly established herein Bukowa Formation (as well as the overlying the Małogoszcz Oolite Formation, and the Spinkowa Góra Formation, all of them corresponding to the "oolitic" formation sensu lato) which differ in their lithological character, and the boundaries of which are placed at strictly defined and easily recognisable characteristic lithological horizons (discontinuity surfaces, marly units, etc; see Fig. 4).

\section{Piekielnica Coral Limestone Member (herein established)}

Name: After Piekielnica hill, the next hill to Bukowa hill, where the old part of Bukowa quarry was founded. (Polish name: ogniwo wapieni koralowcowych z Piekielnicy). The deposits of the unit referred to as "great-reef complex" (II) by Świdziński (1962, fig. 3) crop out along the northern slope of Piekielnica hill in the railway cut.

Type area and type section: South-western margin of the Holy Cross Mts. between Krasocin and Sobków (Kutek, 1968, tab. 2; Pszczółkowski, 1970, fig. 3). The type section is the Bukowa quarry section (Matyja, 2011, fig. 3, where the corresponding beds were designated as the "chalky limestones"), treated always as the most important section of this stratigraphical interval in the area of study (see Roniewicz, Roniewicz, 1971).

Thickness: about 35 meters at Bukowa quarry; in other sections of the SW margin of the Holy Cross Mts. between 30-40 meters in thickness.

Lithology: The member is subdivided into two informal parts. The lower part distinguished as the "basal unit" of a few to several meters in thickness is very contrasted in its lithology: from organodetrital limestones with Marinella (between Staniewice and Biała Nida valley), replaced by micritic limestones with marly intercalations, and by oolitic limestones near Skorków and Gruszczyn (Pszczółkowski, 1970). The "basal unit" at Bukowa quarry, about 8-9 meters in thickness, consists of limestones with corals, towards the 
top replaced by micritic limestones with marly layers up to about 1-2 $\mathrm{m}$ in thickness (see: Kutek, 1968, fig. 7, beds B7, B6, respectively; Matyja, 2011, fig. 3). The upper ("main") part of the member is composed of soft chalky limestones, well bedded (locally with coral biostromes) with a shallowwater fauna - commonly occurring hermatypic corals, gastropods-nerineids, bivalves (diceratids, oysters), brachiopods, crinoids, as well as calcareous algae - solenoporoids, Marinella (see Roniewicz, 1966, 2004; Roniewicz, Roniewicz, 1971). The total thickness of the upper part of the member is about 25 meters in Bukowa quarry section (but possibly was somewhat smaller, less than 20 meters in thickness, in the older part of the quarry, see Roniewicz, Roniewicz, 1971, fig. 5; Roniewicz 2004, appendix).

Boundaries: The lower boundary corresponding to the base of the Bukowa Formation is placed at the prominent discontinuity surface of wide regional extent (see description of formation). The upper boundary is placed at the base of the micritic limestones marking the base of the Leśnica Limestone Member (see description of the unit).

Geological age: Uppermost Planula Zone to lower $\mathrm{Pla}^{-}$ tynota Zone.

Distribution: South-western margin of the Holy Cross Mts., possibly stretching onto the north-western margin, but so far not recognized in detail.

Equivalents: The upper part of the "chalky limestone member" of Kutek (1968), down to the "basal unit" - about 30-35 meters below the top of the chalky limestones (Pszczółkowski, 1970, fig. 3); possibly a lower part of the "lower Kurnędz member $\left(D_{1}\right)$ " as recognized in the northwestern margin of the Holy Cross Mountains by Matyja and Wierzbowski (2014). The marly intercalations at the top of the "basal unit" (recognized also as the marly unit " $\mathrm{mA}$ " by Barwicz-Piskorz, 1995, fig. 4) possibly correspond to some parts of the Latosówka Marl Member in the Polish Jura (see e.g. Wierzbowski, 2017a).

\section{Leśnica Limestone Member (herein established)}

Name: After Leśnica village, where the unit crops out. (Polish name: ogniwo wapieni z Leśnicy).

Type area and type section: South-western margin of the Holy Cross Mts., especially area between Gruszczyn and Leśnica. The characteristic section is in Bukowa quarry described by Roniewicz (1967, fig. 1), Kutek (1968, fig. 7), and Matyja (2011, fig. 3).

Thickness: About 15 meters at Bukowa quarry, generally from several to about 20 meters in thickness.

Lithology: It is a very variable unit lithologically. It consists of micritic limestones and organodetrital-oolitic lime- stones containing bioclasts, intraclasts and ooids in various amounts, and some benthic fauna (Roniewicz, 1967; Kutek, 1968; Pszczółkowski, 1970). In the typical development at Bukowa quarry it is composed of micritic limestones with marly intercalations in its lower part, followed by micritic limestones with admixtures of ooids, onkoids, intraclasts, bioclasts, and covered by cross-bedded oolitic limestones (Roniewicz, 1967; Kutek, 1968). In the southern part of the area between Staniewice and Leśnica the deposits are dominated by oolitic-organodetrital limestones, subdivided by micritic limestones (Pszczółkowski, 1970, figs. 1, 3).

Boundaries: The lower boundary is placed directly at the top of the highest chalky limestone of the Piekielnica Coral Limestone Member, and is often marked by the discontinuity surface (Kaźmierczak, Pszczółkowski, 1968; Pszczółkowski, 1970). In the Bukowa quarry section it corresponds to a sudden lithological change from the chalky limestones to well-bedded micritic limestones with poor fauna (Roniewicz, 2004, appendix: boundary between beds 19 and 20). The upper boundary with the marly limestones of the Góry Marl Member = "lowermost marly horizon" of Kutek (1968) is also often marked by a discontinuity surface (e.g. Kaźmierczak, Pszczółkowski, 1968, fig. 6B).

Geological age: Lower to middle parts of the Platynota Zone.

Distribution: South-western margin of the Holy Cross Mts., possibly stretching onto its north-western margin, but so far not recognized in detail.

Equivalents: The unit was recognized by Kutek (1968) as the "deposits overlying chalky limestones", and as such was described subsequently in several papers on the southwestern margin of the Holy Cross Mts. (e.g., Pszczółkowski, 1970; Gutowski et al., 2006; Matyja, 2011).

\section{Góry Marl Member (Wierzbowski, 2017)}

This was formally distinguished in the Wielun Upland (Wierzbowski, 2017a), recognized there earlier as the "middle marly unit" (Wierzbowski, 1966). It was treated always as strictly corresponding to the "lowermost marly horizon" of the south-western margin of the Holy Cross Mts. (Kutek, 1968).

The Góry Marl Mbr. = "lowermost marly horizon" is the highest member of the Bukowa Formation. It is composed of marls/marly shales and marly limestones. It ranges from some - generally below 10 metres (according to Kutek, 1968), but locally even up to several meters in thickness. The unit occurs in the south-western margin of the Holy Cross Mts. (Fig. 4) except for its northern and southern parts, being replaced there by micritic limestones (Kutek, 1968; Pszczółkowski, 1970). 


\section{MAŁOGOSZCZ OOLITE FORMATION (herein established)}

Name: After Małogoszcz town in the south-western margin of the Holy Cross Mountains, where the formation is fully exposed in a large cement-works quarry. (Polish name: formacja wapieni oolitowych z Małogoszcza).

Type area and type section: South-western margin of the Holy Cross Mts. The type section seen in the cementworks quarry at Małogoszcz was described by Matyja et al. (2006a, fig. B2.30) and Matyja (2011, fig. 4).

Subdivision: The formation is subdivided into four members (in brackets old informal names given after Kutek, 1968): the Rogalów Limestone Member ("underlying pelitic limestones"), the Gluchowiec Oolite Member ("lower oolite"), the Mieronice Banded Limestone Member ("banded limestone member"), the Sobków Oolite Member ("upper oolite"). The Celiny Onkolite Bed ("onkolite horizon") occurs at the top of the formation (Fig. 4).

Thickness: About 60 meters in the type section; from 60-70 meters in other sections.

Lithology: Oolitic limestones varying from showing large scale cross-bedding to being non-cross-bedded are dominant in the oolite members; commonly occurring, moreover, are micritic limestones often with intercalations of fine-grained (oolitic-onkolitic-organodetrital) limestones, including a very characteristic unit of banded limestones composed of alternating bands of micritic limestones and fine-grained limestones often showing ripple cross-bedding with early-diagenetic cherts developed along shrimp burrows (Radwański, 2003); thin onkolitic limestone bed at the top of the formation; discontinuity surfaces common - some of a wider regional distribution (see description of the members), benthic fauna in some parts (especially in non-crossbeded oolites) commonly encountered, represented by diversified bivalve assemblages, brachiopods, various echinoderms, etc. (Kutek, 1968).

Boundaries: Lower boundary at the top of the underlying Góry Marl Member corresponding to the top of the $\mathrm{Bu}-$ kowa Formation marked by the widely distributed discontinuity surface (Chudzikiewicz, Wieczorek, 1985, fig. 2; see also Krajewski et al., 2014, where the surface is discussed, but note also the critical comments herein on some aspects of its interpretation by these authors). Upper boundary at the top of the Celiny Onkolite Bed, and the overlying marly deposits of the Spinkowa Góra Formation (see Matyja et al., 2006, fig. B2.31 - where this boundary is arrowed).

Geological age: Upper part of the Platynota Zone to lowermost part of the Hypselocyclum Zone.

Distribution and age equivalents: South-western margin of the Holy Cross Mountains. The oolite units recognized in the north-western margin of the Holy Cross Mts. and in the Szczerców-Bełchatów area are mostly not ageequivalents of the formation (see Wierzbowski, 2017a; Wierzbowski, Głowniak, 2018). Although the correlation between the oolite units of the north-eastern and south-western margins of the Holy Cross Mts. is not clear in detail, the "Wierzbica oolite and platy limestones", and the "Ożarów oolite and platy limestones" can be considered as possible equivalents of the Małogoszcz Oolite Formation ( $c f$. Gutowski, 1992, 1998, 2006). The formation can be recognized also in some of the cores in the Miechów Synclinorium, such as Węgleszyn IG-1 (see Jurkiewicz et al., 1969, fig. 3).

\section{Rogalów Limestone Member (herein established)}

Name: After Rogalów village in the south-western margin of the Holy Cross Mts., where the deposits of the unit attain a larger thickness and have yielded ammonites ( $c f$. Kutek, 1968, tab. 2). (Polish name: ogniwo wapieni z Rogalowa).

Type area: South-western margin of the Holy Cross Mts. (Kutek, 1968, tab. 2; Pszczółkowski, 1970, fig. 3). The most representative sections are: (1) of Sobków quarry elaborated in detail by Chudzikiewicz and Wieczorek (1985, fig. 2, from bed 2 to bed 10); (2) of Bukowa quarry described by Matyja (2011, fig. 3, see also description in p. 142); (3) of Rogalów compiled by Malinowska (1970, fig. 2, bed (member) 12; after Świdziński, 1962, fig. 9).

Thickness: From $2.6 \mathrm{~m}$ at Bukowa quarry to about 10 15 meters (commonly); the thickness of about 20 meters as corresponding to the upper part of the "platy" unit in the Rogalów section ( $c f$. Malinowska, 1970, fig. 2), however, seems too large ( $c f$. Kutek, 1968; Pszczółkowski, 1970).

Lithology: Micritic limestones commonly with bioclasts, and ooids, and with marly intercalations, especially characteristic of the middle part of the unit (Chudzikiewicz, Wieczorek, 1985; Matyja, 2011). Intercalations of oolitic limestones are common in the upper part of the unit.

Boundaries: Lower boundary with the Góry Marl Mbr. of the topmost part of the Bukowa Formation along the prominent discontinuity surface often covered by a layer with bored and encrusted carbonate clasts (Chudzikiewicz, Wieczorek, 1985, fig. 2, base of bed 2). Upper boundary with the Gluchowiec Oolite Member placed at the base of the uniform set of oolitic limestones, often marked by a discontinuity surface (Chudzikiewicz, Wieczorek, 1985, fig. 2, base of bed 11).

Geological age: Upper part of the Platynota Zone.

Distribution and equivalents: South-western margin of the Holy Cross Mts. The unit is replaced laterally by the oolitic limestones of the Gluchowiec Oolite Member ("lower 
oolite") as e.g. at Wola Świdzińska in the northern part of the study area (Kutek, 1968, tab. 2).

The unit was originally recognized informally by Kutek (1968) as the "underlying pelitic limestones", and as such was described in several papers (e.g. Matyja et al., 2006a; Matyja, 2011). Occasionally, however, it was included in the "lowermost marly horizon" = Góry Marl Member (Chudzikiewicz, Wieczorek, 1985), but successively transferred into the "underlying pelitic limestones" (Krajewski et al., 2014, p. 123). In older geological literature it was treated jointly with underlying marls (= Góry Marl Member), and pelitic limestones with marls (= Leśnica Limestone Member) as corresponding to the "platy complex" (III) of Świdziński (1962; see also Malinowska, 1970).

\section{Głuchowiec Oolite Member (herein established)}

Name: After Głuchowiec quarry at Małogoszcz, where this unit is exposed, and it has been described from the neighbouring quarry at Mieronice (Kutek, 1962a). (Polish name: ogniwo wapieni oolitowych z Gluchowca).

Type area and type section: South-western margin of the Holy Cross Mts. The most typical development is between Skorków and Małogoszcz. The type section is in the large cement-works quarry at Małogoszcz described by Matyja et al. (2006a, fig. B2.30) and Matyja (2011, fig. 4).

Thickness: Between 10 and 20 meters.

Lithology: The most typical deposits are large-scale cross-bedded oolites, which are commonly encountered between Skorków and Mieronice; in other areas there occur also oolitic limestones not showing cross-bedding (Kutek, 1969). The macrofossils are very rare, mostly "pulverized to ooid size or lesser, and thus cannot be recognized taxonomically" (Radwańska, Radwański in: Matyja et al., 2006a, p. 194).

Boundaries: Lower boundary with the Rogalów Limestone Member placed at the base of the uniform set of oolitic limestones often showing cross-bedding, and marked by the omission surface (Chudzikiewicz, Wieczorek, 1985, fig. 2, base of bed 11). Upper boundary with the Mieronice Banded Limestone Member placed at the base of the first layer composed of alternating bands of micritic and grained limestones typical of the latter unit.

Geological age: Upper part of the Platynota Zone.

Distribution: The member occurs in the south-western margin of the Holy Cross Mts., but it cannot be recognized further northward, already at Mojżeszów and Dobromierz, directly outside the study area (Świdziński, 1962; Kutek, 1968).
Equivalents: The unit was recognized by Świdziński (1962) as the "Astartian oolite" in the lowermost part (member 13) of his "main oolite complex" (IV). It was distinguished also as the "lower oolite" by Kutek (1968, tab. 2) and under this name described in several papers (e.g. Pszczółkowski, 1970; Matyja et al., 2006a; Matyja, 2011).

\section{Mieronice Banded Limestone Member (herein established)}

Name: After Mieronice quarry, from where the section was described by Kutek (1962a). (Polish name: ogniwo wapieni pasiastych z Mieronic).

Type area and type section: South-western margin of the Holy Cross Mts. between Skorków, Małogoszcz and Mieronice where it shows the most typical development (Kutek, 1969). The type section is in the large cement-works quarry at Małogoszcz (Matyja et al., 2006a, fig. B2.30; Matyja, 2011, fig. 4); the reference section is at Mieronice quarry (Kutek, 1962a, fig. 1; Kutek, 1969, pl. 13: 1, 2).

Thickness: from a few to about 20 meters.

Lithology: In typical development limestones composed of alternating bands of micritic and grained limestones, some of the latter displaying ripple-cross bedding. The white-colored flints occurring at many horizons represent silica concentrations contouring the burrows of alpheid shrimps (Radwański, 2003). Outside the area of typical development other lithologies are also encountered: micritic limestones not showing the banded structure and devoid of cherts; locally also oolitic limestone bodies, as e.g. at Bolmin (Pszczółkowski, 1970, figs 2, 4).

Boundary: Lower boundary with the Gluchowiec Oolite Mbr. is placed at the base of the uniform set of banded/ micritic limestones. Upper boundary with the overlying Sobków Oolite Mbr. at the prominent discontinuity (hardground) surface of large regional extent (Kaźmierczak, Pszczółkowski, 1968, fig. 2, between units 8 and 9; figs 4, 5; pl. 1: 1, 2; Kutek, 1969, pl. 13: 2, between units b and a; see also Figs 4, 7, herein). A coralliferous biostrome, about 2 meters thick and of a large lateral extent (over $5 \mathrm{~km}$ ) is developed at the top of the Mieronice Banded Limestone Member at Brzegi and Żerniki (Roniewicz, Roniewicz, 1968, fig. 1): the biostrome is present at the top the hardground surface at the junction with the overlying Sobków Oolite Member.

Geological age: Upper part of the Platynota Zone.

Distribution and equivalents: South-western margin of the Holy Cross Mts.; the occurrence of the banded limestones typical of this unit is not known outside this area (Świdziński, 1962; Kutek, 1968). The unit was recognized 
as representative of the middle part (member 14) of the "main oolite complex" (IV) by Świdziński (1962), and subsequently as the "banded limestone member" by Kutek (1968, 1969; see also e.g. Pszczółkowski, 1970; Matyja et al., 2006a; Matyja, 2011).

\section{Sobków Oolite Member (herein established)}

Name: After Sobków quarry in the south-western margin of the Holy Cross Mts., from where the deposits of the unit were described and yielded ammonites (Kutek, 1968; see also Pastusiak, 1987). (Polish name: ogniwo wapieni oolitowych z Sobkowa).

Type area and type section: South-western margin of the Holy Cross Mts. The type section is that of the cement-works quarry at Małogoszcz (Matyja et al., 2006a, fig. B.2.30; Matyja, 2011, fig. 4); the reference sections at Sobków quarry (after Pastusiak, 1987: re-illustrated herein in Fig. 7).

Thickness: from about 20 to 35 meters.

Lithology: Oolitic limestones commonly with shell detritus, partly showing cross-bedding, but large parts are not cross-bedded. Some fragments of the unit, especially of its upper part, are represented by micritic limestones with streaks and other concentrations of grained material (ooids, onkoids, intraclasts, bioclasts) (see Kutek, 1968; Kutek, 1969, pl. 13: 2; pl. 14: 1; Pszczółkowski, 1970; see also Fig. 7, herein). Macrofauna abundant: brachiopods, serpulids, very diversified bivalve assemblages, gastropods, various echinoderms (echinoids, crinoids, starfishes, ophiuroids), ammonites (Świdziński, 1962; Kutek, 1968; Radwańska, Radwański in: Matyja et al., 2006a); common Thalassinoides burrows. Discontinuity surfaces both of the softground and the hardground type commonly encountered (Kaźmierczak, Pszczółkowski, 1968; Gruszczyński, 1986; Pastusiak, 1987).

Boundaries: Lower boundary with the Mieronice Banded Limestone Member placed at the change of lithology into dominant oolitic limestones and above the prominent discontinuity surface (hardground) (see description of the Mieronice Banded Limestone Mbr., see also Fig. 4, herein). Upper boundary also at the discontinuity surface of especially large extent in the south-western margin of the Holy Cross Mts., and being the boundary with the overlying onkolitic limestones of the Celiny Onkolite Bed (see Kutek, Radwański, 1967, fig. 1; Kutek, 1969, pl. 15: 2; Kaźmierczak, Pszczółkowski, 1968, fig. 2, between units 9 and 10; Gruszczyński, 1986).

Geological age: Upper part of the Platynota Zone to lowermost part of the Hypselocyclum Zone (lussasense horizon).
Distribution and equivalents: South-western margin of the Holy Cross Mts. The unit was distinguished originally as the "Kimmeridgian oolite" (member 15) of the upper part of "main oolite complex" (IV) by Świdziński (1962), and then as the "upper oolite" by Kutek (1968; see also e.g. Pszczółkowski, 1970; Matyja et al., 2006a; Matyja, 2011).

\section{Celiny Onkolite Bed (herein established)}

Name: After Celiny village in the south-western margin of the Holy Cross Mts., where this unit cropped out in an old quarry (Kutek, Radwański, 1965, 1967). (Polish name: warstwa onkolitu z Celin; onkolit z Celin).

Type area and type section: South-western margin of the Holy Cross Mts. The type section is at an old quarry at Celiny (Kutek, Radwański, 1967, fig. 1; Kutek, 1969, pl. 15: $2)$; the reference section at the large cement-works quarry at Małogoszcz (Matyja et al., 2006a, figs B.2.30, 31; Matyja, 2011, fig. 4).

Thickness: From several centimeters to few meters (about $0.20 \mathrm{~m}$ at Małogoszcz, about 2 meters at Celiny); the marked difference in thickness results from the location of the bed near the discontinuity surface - in some sections it is missing.

Lithology: Onkolitic limestones composed of densely packed bean-shaped pisoonkoids usually about $1.5 \mathrm{~cm}$ in diameter, the largest up to about $2.5 \mathrm{~cm}$, occurring in a sparse micritic matrix (Kutek, Radwański, 1965). Onkoids developed commonly around fragments of oyster shells, often bored by bivalves and overgrown by different encrusting animals (oysters, serpulids, bryozoans - Kutek, Radwański, 1965).

Boundaries: Lower boundary marked by the prominent discontinuity surface (hardground) of very large lateral extent (Fig. 4). The underlying deposits of the Sobków Oolite Member are erosionally truncated and bored by lithophags (Kutek, Radwański, 1967; Kaźmierczak, Pszczółkowski, 1968; Gruszczyński, 1986). The upper boundary with the Spinkowa Góra Formation is placed at the base of the marly unit (Kiełczygłów Marl Member).

Geological age: Lower part of the Hypselocyclum Zone.

Distribution: The Celiny Onkolite Bed is seen all over the whole south-western margin of the Holy Cross Mts., and also it occurs outside, forming everywhere a good marker horizon. It should be noted that in the southern part of the area of study from Brzegi towards the south, the position of the bed in the succession changes suddenly into a level placed some meters higher (see Kutek, 1968). The discussed bed is traced in the adjoining part of the north-western mar- 
gin of the Holy Cross Mts., being recognized between Dobromierz and Przedbórz (Kutek, 1968); also from the Radomsko elevation (Wierzbowski, Głowniak, 2018, figs. 2, 3 , onkolites at the top of bed 9).

Equivalents: Distinguished as the "pisolitic horizon" (member 16) in the uppermost part of the "main oolite complex" (IV) by (Świdziński, 1962), and as the "onkolite horizon" by Kutek (1968, 1969; see also e.g. Matyja et al., 2006a; Matyja, 2011).

\section{SPINKOWA GÓRA FORMATION (herein established)}

Name: After Spinkowa hill at the southern edge of the large cement-works quarry at Małogoszcz. (Polish name: formacja ze Spinkowej Góry).

Type area and type section: South-western margin of the Holy Cross Mts. between Lipie, Gruszczyn Skorków and Mieronice, where the unit shows its most typical development. The type section is at the large cement-works quarry at Małogoszcz (Matyja et al., 2006a, figs. B.2.30-B.2.32; Matyja, 2011, fig. 4).

Subdivision: The formation is subdivided into four members: the Kiełczygłów Marl Member originally distinguished by Wierzbowski (2017a) in the Wielun Upland, and the adjacent Szczerców-Bełchatów area, and the three members newly distinguished herein: the Grabki Limestone Member, the Dobromierz Marl Member, and the Buczyna Limestone Member (Fig. 4).

Thickness: About 40 to 50 meters.

Lithology: Micritic limestones with subordinate intercalations of organodetrital-oolitic-onkolitic limestones, sometimes also of oyster coquina beds, micritic "sublithographic" limestones, marly limestones and marls.

Boundaries: The lower boundary with the Małogoszcz Oolite Formation is placed at the top of the Celiny Onkolite Bed (see above). Upper boundary with the "coquina" formation $=$ Skorków lumachelle of Kutek (1968) placed at the prominent discontinuity surface (hardground) at the top of the sublithographic limestones of the Buczyna Limestone Member (see Kaźmierczak, Pszczółkowski, 1968, fig. 2, between units 13 and 14; Gruszczyński, 1986; Matyja et al., 2006a, fig. B.2.32; Fig. 4). This boundary is also the boundary of the two tectono-stratigraphic sequences $\mathrm{COK}$ and LUK, recognized in the territory of central Poland by Kutek (1994, figs. 11, 12).

Geological age: Lower to upper parts of the Hypselocyclum Zone.

Distribution: In its typical development between Lipie and Mieronice in the south-western margin of the Holy
Cross Mts. Towards the north and south successively replaced by oolitic limestones, which belong possibly to separate lithostratigraphic units, not fully recognized so far.

Equivalents: The deposits attributed to the formation were referred in the past to "complex V" composed of wellbedded limestones with intercalations of oolites and oyster lumachelles, and marls as described by Świdziński (1962). The formation corresponds also to the "oolite-platy member" and the "shaly limestones and underlying clays" of Kutek (1968): the former is subdivided herein into: the Kiełczygłów Marl Member and the Grabki Limestone Member, the latter into - the Dobromierz Marl Member and the $\mathrm{Bu}$ czyna Limestone Member.

\section{Kiełczygłów Marl Member (Wierzbowski, 2017)}

The marly unit recognized in the lowermost part of the Spinkowa Góra Formation (Fig. 4), attaining a few meters in thickness (about $5 \mathrm{~m}$ in the large cement-works quarry at Małogoszcz) is strictly comparable with the Kiełczygłów Marl Member as recognized in the north-eastern margin of the Wielun Upland, and in the Burzenin area (Wierzbowski, 2017a, figs. 4, 6, 7). The same unit is recognized in the Szczerców-Bełchatów area, where it corresponds to "unit B" seen in several boreholes (Wierzbowski, 2017a, fig. 5). It was distinguished as the "F-9 facies" in other boreholes in the same area by by Olchowy et al., 2019 (figs 2, 3, 5), but wrongly compared with the "lowermost marly horizon" = Góry Marl Member of the south-western margin of the Holy Cross Mts. (see also comments in chapter on facies succession and stratigraphical interpretation, herein). The Kiełczygłów Marl Member was also recognized at Rogaszyn quarry in the Radomsko elevation (Wierzbowski, Głowniak, 2018, figs. 2, 3, bed 10). It is thus a well-defined marker level of high correlation value.

\section{Grabki Limestone Member (herein established)}

Name: After Grabki hill at the large cement-works quarry at Małogoszcz where the type-section of the unit is located. (Polish name: ogniwo wapieni z Grabek).

Type area and type section: South-western margin of the Holy Cross Mts., between Lipie and Mieronice, where the unit shows its most typical development. Type section is in the large cement-works quarry at Małogoszcz (Matyja et al., 2006a, figs. B.2.30, B.2.31 - corresponding to the "oolite-platy member", which includes the Kiełczygłów 
Marl Member at the base and the Grabki Limestone Member above; Matyja, 2011, fig. 4).

Thickness: About $15-20$ meters (12 meters at Małogoszcz quarry).

Lithology: In typical development micritic limestones with subordinate intercalations of organodetrital-ooliticonkolitic limestones, sometimes also of oyster coquina beds. In some other areas oolitic limestones are also recognized.

Boundaries: The lower boundary at the top of the Kietczygłów Marl Member is placed at the base of a thicker limestone bed above the marly interval. Upper boundary with the Dobromierz Marl Member placed at the base of the thicker fairly uniform marly unit (Fig. 4).

Geological age: Lower part of the Hypselocyclum Zone.

Distribution and equivalents: South-western margin of the Holy Cross Mts., towards the north successively replaced by oolitic limestones, towards south difficult for precise recognition due to the disappearance of the overlying marly unit (Dobromierz Marl Member), and the appearance of larger bodies of the oolitic limestones (see Kutek, 1968, tab. 2; Pszczółkowski, 1970, fig. 3).

Together with the Kiełczygłów Marl Member it corresponds to the "oolite-platy member" between Mieronice and Oleszno (in its typical development), and further north-west, between Dobromierz and Przedbórz, where the oolitic limestones predominate (Kutek, 1968, tab. 2, fig. 11).

\section{Dobromierz Marl Member (herein established)}

Name: After Dobromierz village, north of the study area, where the reference section of the unit is established. (Polish name: ogniwo margli z Dobromierza).

Type area and type section: South-western margin of the Holy Cross Mts. between Mieronice and Oleszno, and further outside the study area between Dobromierz and Przedbórz (Kutek, 1968, tab. 2, fig. 11). The type section is the large cement-works quarry at Małogoszcz, the reference section at Dobromierz in the southern part of the Dobromierz anticline, directly south of Kowale hamlet, where temporary outcrops of the unit existed in the past (Fig. 8).

Thickness: Between 10 and 20 meters (about $12 / 18 \mathrm{~m}$ in the type section, and about 10 in the reference section).

Lithology: Grey to blue-grey marls with thin, a few centimeters in thickness, intercalations of marly limestones; macrofauna not recognized.

Boundaries: The lower boundary with the Grabki Limestone Member is placed at the level of dominance of marls in the succession, and locally marked (e.g. at Małogoszcz quarry) by the distinct discontinuity surface (Matyja et al., 2006a). Upper boundary with the Buczyna Limestone Member placed at the base of the first thicker bed of the sublithographic limestones (Fig. 4).

Geological age: Hypselocyclum Zone, near the boundary between the lower (Hippolytense Subzone), and the upper part (Lothari Subzone).

Distribution: South-western margin of the Holy Cross Mts., and adjacent northern areas between Dobromierz and Przedbórz; towards the south the unit disappears (Kutek, 1968, tab. 2; Pszczółkowski, 1970; see also Fig. 4, herein).

Equivalents: The Dobromierz Marl Member as recognized herein corresponds to the lower, marly part of the "shale limestones and underlying clays" of Kutek (1968). It was also recognized by Barwicz-Piskorz (1995, fig. 4) as "marls E". A possible marly equivalent at the north-eastern margin of the Wielun Upland and adjacent SzczercówBełchatów area is the "unit E" as distinguished by Wierzbowski (2017a, figs. 5, 6).

\section{Buczyna Limestone Member (herein established)}

Name: After Buczyna hill, the natural reserve area at the northern limb of the Dobromierz Anticline, where the unit crops out (cf. Świdziński, 1935). (Polish name: ogniwo wapieni z Buczyny).

Type area and type section: South-western margin of the Holy Cross Mts., from Małogoszcz to Oleszno, and adjacent area from the north between Żeleźnica, Dobromierz and Przedbórz. Type section is the large cement-works quarry at Małogoszcz (Matyja et al., 2006a, figs B.2.30, B.2.32; Matyja, 2011, fig. 4). Reference section near Dobromierz at Buczyna hill (see Świdziński, 1935, fig. 9), and an unnamed hill south of Kowala hamlet (see Figs. 2, 4, 8, herein).

Thickness: $7-10$ meters in the south-western margin of the Holy Cross Mts., and larger up to $20 \mathrm{~m}$ towards the north, mostly outside the study area between Oleszno, Mojżeszów, Dobromierz and Przedbórz (Kutek, 1968, tab. 2, fig. 11).

Lithology: In the south-western margin of the Holy Cross Mts., thin-bedded micritic "sublithographic" limestones splitting into thin flags when weathered, with thin marly intercalations; fauna very poor and specific (small bivalves, special isopod and marine reptile rests - see Radwański, Radwańska in: Matyja et al., 2006a, with references given).

A different lithology is observed in the uppermost part of the unit, north of the area of study, as recognized most completely at Dobromierz (Radwański, 1960; Wierzbowski, 1961; see Figs. 2 and 8, herein). This part of the unit, seen only here, is at least about 7 meters in thickness. It is composed of oolitic-organodetrital limestones alternating with micritic 
limestones and marl; the thickness of the particular beds of these two lithologies oscillates from several centimeters to about 2 meters; a thick marly bed about 2-3 meters in thickness, showing markedly erosional contact with the underlying micritic limestones, is observed at the top of the member; lenses of fine-grained limestones with erosional upper boundaries interpreted originally as flow-folds (possibly load-casts) are commonly encountered (Radwański, 1960, pl. 16: 1-3); the erosional boundaries, the discontinuity surfaces (hardgrounds), and clasts bored by lithophags are common in the whole studied interval (see Kutek, 1994, fig. 12B). Abundant (about 15-20\%) small quartz grains (about $0.1 \mathrm{~mm}$ in size) are encountered in beds and clasts of oolitic-organodetrital limestones.

Boundaries: Lower boundary with the Dobromierz Marl Member placed at the level, where the micritic limestones become dominant. Upper boundary placed at the top of the micritic "sublithographic" limestones and marked by the prominent discontinuity (hardground) surface ("main hardground" after Radwański, Radwańska in: Matyja et al., 2006a, p. 196) in the south-western margin of the Holy Cross Mts.; it represents here the boundary between the Spinkowa Góra Formation and the Skorków lumachelle ("coquina") formation (see Matyja et al., 2006a, figs. B.2.30, B.2.32; see also comments above; see Fig. 4). The upper boundary of the member in the northern areas (such as the Dobromierz section) is placed directly at the top of the last micritic limestone or marly bed, directly below the overlying oyster coquinas belonging to the Skorków lumachelle/ "coquina" formation of Kutek $(1968,1994)$.

Distribution and equivalents: The main problem remains the stratigraphical relation between the micritic sublithographic limestones of the Buczyna Limestone Mbr. in the south-western margin of the Holy Cross Mts., and the uppermost part of the member, showing the intercalations of oolitic-organodetrital limestones with common discontinuity surfaces in the north, mostly outside the area of study. According to Kutek (1994, fig. 12 B), the upper parts of the member are of similar age in both areas, and the differences in development resulted from the fact that "biodetrital and biomicritic layers isochronous but of a limited areal extent (...) in most cases peter out within micritic sediments". However, as another interpretation, it is also possible that the upper part of the Buczyna Limestone Member in the northern areas is younger and not represented in the succession in the south-western margin, where a stratigraphical gap at the top of the member occurs.

The Buczyna Limestone Member corresponds to the upper part of the "shaly limestones and underlying clays" of Kutek (1968). 


\section{Appendix 2}

\section{AMMONITE SYSTEMATIC PALAEONTOLOGY}

The following abbreviations are used in the description of the ammonites: D - diameter of specimen in $\mathrm{mm}$; Wh whorl height as a percentage of $\mathrm{D}$; $\mathrm{Ud}$ - umbilical diameter as a percentage of $\mathrm{D}$; $\mathrm{PR}$ - number of primary ribs per whorl (or PR/2 - per half a whorl); SR/PR - secondary/primary rib ratio counted on 5 primary ribs at given diameter.

The review of ammonites given below concentrates on forms unknown so far or poorly represented from the territory of Poland, as well as on specimens described in older papers when their new systematic interpretation is given herein.

The ammonites studied come mostly from the collection housed in the Museum of the Geological Faculty of the University of Warsaw (especially the collection number ZI/100/1-40), including both the older specimens of J. Kutek (described in his study from 1968), but also new ones gathered later. Some specimens described by Matyja (1977) and Matyja et al. (1989) - collection number ZI/22 are also preserved in the Museum of the Geological Faculty of Warsaw.

\section{FAMILY ATAXIOCERATIDAE BUCKMAN, 1921}

Genus Orthosphinctes Schindewolf, 1925 (Pls 1, 2, 3: 1). The ammonites of the genus are interpreted according to Atrops (1982), who distinguished two groups of microconchs attributed to the subgenera Orthosphinctes Schindewolf, 1925 and Ardescia Atrops, 1982, and one group of macroconchs attributed to the subgenus Lithacosphinctes Oloriz, 1978 according to the morphotaxonomical interpretation of the genus. Two large specimens of Lithacosphinctes were described previously from the area of study by Kutek (1968) under the genus name Lithacoceras according to the older classification of Geyer (1961). Both of them need special comment because of their different species interpretation as presented herein. The specimen described as "Lithacoceras subachilles (Wegele)" by Kutek (1968, p. 550, pl. 2) from the Sobków Oolite Member ("upper oolite") in Sobków quarry is closely comparable with Orthosphinctes (Litahcosphinctes) pseudoachilles (Wegele) as interpreted by Atrops (1982) - it shows a similar coiling (weakly involute to weakly evolute on the inner whorls, and markedly evolute on the outer whorl), attains large size (D is about $300 \mathrm{~mm}$ ), and reveals a similar rib density during ontogeny, and a high $\mathrm{SR} / \mathrm{PR}$ ratio (near 7-8) at $\mathrm{D}=200 \mathrm{~mm}$. Another specimen referred to as "Lithacoceras evolutum (Quenstedt)" by Ku- tek (1968, p. 550, pl. 3; see also Pl. 1, herein) from the Rogalów Limestone Member ("underlying pelitic limestones") in Rogalów quarry differs from Orthosphinctes (Lithacosphinctes) evolutum (Quenstedt) as defined by Atrops (1982) mostly in the character of the inner whorls: a smaller number of ribs (PR is about 37 at $\mathrm{D}=60 \mathrm{~mm}$, and it can be calculated to be about $30-32$ at $\mathrm{D}=140 \mathrm{~mm}$ ), a more rounded whorl section, and a more evolute coiling. These features are typical of Orthosphinctes (Lithacosphinctes) stromeri (Wegele) according to Atrops (1982), but the specimens of this species as known so far differ in their smaller final size - the lectotype attains possibly about $145-150 \mathrm{~mm}$ in its final diameter (see Wegele, 1929, pl. 7: 4), and another specimen illustrated by Atrops (1982, pl. 2: 3) has the peristome preserved at about $145 \mathrm{~mm}$ diameter. The specimen studied (Pl. 1) is markedly larger, attaining at least $245 \mathrm{~mm}$ in final diameter (i.e. its shell is at least a one whorl longer than the two specimens of this poorly known species discussed above, and it reveals the presence of single swollen ribs occurring on the last fragment of whorl preserved unknown in the specimens described so far). Thus, the studied specimen is referred to as Orthosphinctes (Lithcosphinctes) aff. stromeri (Wegele). It should be remembered that $O$. (L.) stromeri was identified by Atrops (1982, p. 145) as a macroconch counterpart of the early microconchs of the Orthosphinctes (Ardescia) inconditus (Fontannes) group and not of Orthosphinctes (Orthosphinctes) polygyratus (Reinecke), which is an older microconch counterpart of $O$. (L.) evolutum.

The giant specimen from Bukowa quarry (collected by M. Hofman) derives from micritic limestones of the Leśnica Limestone Member of the Bukowa Formation (Pl. 2). It attained about $450 \mathrm{~mm}$ in final size, but the last $3 / 4$ of whorl is not preserved. The specimen is $330 \mathrm{~mm}$ in diameter - it shows an evolute coiling of the last whorl preserved (at $\mathrm{D}=330 \mathrm{~m}, \mathrm{Wh}=29, \mathrm{Ud}=40$ ), and a weakly involute coiling of the inner whorls (at $\mathrm{D}=210 \mathrm{~mm}, \mathrm{Wh}=39, \mathrm{Ud}=35$ ). The ribbing of the outer whorl consists of loosely-spaced thick primaries (at $\mathrm{D}=330 \mathrm{~mm}, \mathrm{PR}=25$ ) and very numerous secondaries (at $\mathrm{D}=330 \mathrm{~mm}, \mathrm{SR} / \mathrm{PR}=10$ ). The ribbing on the inner whorls, only partly visible, is very dense (at $\mathrm{D}=180 \mathrm{~mm}$, up to the distinct constriction, the number of primary ribs per half a whorl equals 27). The character of ornamentation of the specimen is very close to Orthosphinctes (Lithcosphinctes) gidoni Atrops. It is worth noting that the described specimen is markedly larger than all specimens attributed so far to that species which only attained up 
to about $250 \mathrm{~mm}$ in diameter (see Atrops, 1982; Wierzbowski, 2017a). Beside the difference in final size, there are marked differences in the diameters marking the particular stages of shell development between the discussed specimens. It is the case e.g. of later disappearance of secondary ribs (still observed at $330 \mathrm{~mm}$ diameter in the specimen studied, but normally disappearing at 190-200 mm diameters) or the maximum diameters at which involute coiling of the shell is observed (at $180 \mathrm{~mm}$ in the specimens studied, but only about $120-140 \mathrm{~mm}$ in other specimens) (see Atrops, 1982; Wierzbowski, 2017a).

When comparing the three discussed macroconchs of Lithacosphinctes - L. subachilles, $L$. aff. stromeri, and $L$. gidoni coming from the shallow-water deposits of the Holy Cross Mts. with their counterparts generally coming from deeper-water deposits of south-eastern France and central Poland (Wielun Upland), it may be noticed that the former generally show larger sizes and some differences in shell development. This can be explained by heterochrony - possibly resulting from the prolonged duration of growth of the ammonite shell and its later offset as controlled by unstable environmental conditions. The problem needs, however, further studies and is beyond the scope of the present paper.

Beside the discussed Lithacosphinctes ammonites, some specimens of the genus Orthosphinctes come from the $\mathrm{Bu}$ kowa Formation in Bukowa quarry and Krzyżowa Góra and/or Głuchowiec quarry. These include typical microconch representatives of Orthosphinctes (Orthosphinctes) polygyratus (Reinecke) (Pl. 3: 1), and a fragment of a large whorl of a macroconchiate $O$. (Lithacosphinctes), which is densely ribbed and could possibly correspond to $O$. (L.) evolutus (Quenstedt).

Genus Ataxioceras Fontannes, 1879 (Pl. 3: 2-4). This is interpreted according to Atrops (1982), who distinguished two microconchiate genera, Parataxioceras Schindewolf, 1925 and Schneidia Atrops, 1982, and the nominative subgenus Ataxioceras for the macroconchs.

The oldest assemblage of ammonites comes from the Sobków Oolite Member ("upper oolite") and the Celiny Onkolite Bed ("onkolite horizon") of Sobków quarry. The specimen described originally as "Ataxioceras ex gr. discobolum (Font.)" by Kutek (1968, pl. 4: 4) is a microconch about $120 \mathrm{~mm}$ in diameter showing a lappeted peristome; the coiling is moderately evolute (at $\mathrm{D}=90 \mathrm{~mm}, \mathrm{Wh}=36$, $\mathrm{Ud}=42$ ). The specimen shows close affinity to Ataxioceras (Parataxioceras) homalinum Schneid, being very similar to its lectotype as illustrated by Schneid (1944, pl. 5: 1) and Geyer (1961, pl. 15: 1), and discussed by Atrops (1982). Specimens of this species were recently described by Wierzbowski (2017a, pl. 5: 2, 3) from the Wielun Upland. Another specimen, which can be compared with the subgenus Parataxioceras, is about $75 \mathrm{~mm}$ in diameter, shows a moderately evolute coiling (at $\mathrm{D}=75 \mathrm{~mm}, \mathrm{Wh}=34.5, \mathrm{Ud}=42.5$ ) and a rather dense ribbing $(\mathrm{PR}=38)$ with fairly high $\mathrm{SR} / \mathrm{PR}$ ratio equaling about 3.8-4.0. This specimen, although incomplete, can be referred to as Ataxioceras (Parataxioceras) cf. hippolytense Atrops (Pl. 3: 4).

Another assemblage consists of highly involute specimens, which can be referred to the subgenus Schneidia. Here belongs a highly involute form (at $\mathrm{D}=91 \mathrm{~mm}$, $\mathrm{Wh}=40.7, \mathrm{Ud}=27.5$ ) covered with dense ribs (at $\mathrm{D}=90$ $\mathrm{mm}, \mathrm{PR} / 2=17$, and $\mathrm{SR} / \mathrm{PR}=3.0$ ) coming from the Sobków Oolite Member ("upper oolite") in the large cement-works quarry at Małogoszcz (Pl. 3: 2). This specimen represented by the phragmocone (up to about $85 \mathrm{~mm}$ diameter) and a fragment of the body chamber can be safely compared with Ataxioceras (Schneidia) lussasense Atrops (cf. Atrops, 1982, p. 177). Another highly involute specimen described by Kutek (1968, pl. 5: 4a, b) as "Ataxioceras (Ataxioceras) involutum Geyer" from the same unit in Sobków quarry belongs to the subgenus Schneidia as well, but it is too poorly preserved for specific identification. Undoubtedly the most difficult one for closer identification is a nicely preserved specimen coming from the same locality and originally referred to by Kutek (1968, p. 552, pl. 5: 1) as "Ataxioceras (Ataxioceras) guentheri (Oppel)". The specimen shows involute coiling (at $\mathrm{D}=83 \mathrm{~mm}, \mathrm{Wh}=41, \mathrm{Ud}=29$; at $\mathrm{D}=$ $67 \mathrm{~mm}, \mathrm{Wh}=42, \mathrm{Ud}=29$ ), and moderately dense ribbing (at D about $65-83 \mathrm{~mm}, \mathrm{PR}=23-24$ ), with a very high SR/ PR ratio equaling about 6.5 . This specimen should not be compared, however, with A. guentheri of Oppel (1863, pl.66: 1), because the latter is very poorly defined, and the type specimen is lost (Atrops, 1982, p. 181). It should be remembered that specimens compared with Ataxioceras guentheri (Oppel) by Geyer (1961, p. 60) have been referred to as Ataxioceras (Schneidia) lussasense by Atrops (1982, p. 177), but the discussed specimen of Kutek (1968) differs in its markedly smaller number of primary ribs. It is possible that this specimen represents an extremely loosely-ribbed representative of the latter species, or possibly it belongs to another poorly known species of the genus Schneidia. Similarly looking specimens were described by Gygi (2003, p. 111, fig. 127a-d) and referred to as Ataxioceras (Schneidia) genuinum Schneid (see also Schneid, 1944, pl. 3: 7-9) with the comment that their "dimensions and the ribbing resemble Ataxioceras (Schneidia) lussasense" although the "ribbing is stronger".

\section{FAMILY AULACOSTEPHANIDAE SPATH, 1935}

Two main groups of aulacostephanids belonging to different lineages are represented in the lower part of the succession, which corresponds to the Platynota-lower Hypselo- 
cyclum zones. One of them is the Submediterranean or NE European Subboreal group (see Matyja, Wierzbowski, 1995; Wierzbowski et al., 2016) represented by macroconch genera: Vielunia Wierzbowski et Glowniak, 1995, and its descendants Eurasenia Geyer, 1961 and Involuticeras Schneid, 1917 (Pls. 8, 9), and corresponding microconchs, mostly of the Prorasenia Schindewolf, 1925 type. The problems of their classification were discussed recently by Wierzbowski (2017a) on the occasion of the occurrence of these ammonites in coeval deposits in the Wielun Upland of central Poland.

These ammonites are represented in older deposits mostly by infrequent giant specimens - attaining about 300 $400 \mathrm{~mm}$ in diameter, and thus representing typical "megaconchs". Such a specimen is "Ringsteadia (Ringsteadia) sp." as described by Kutek (1968, pl. 9) from Bukowa quarry. It is closely comparable with "Ringsteadia tenuiplexa (Quenstedt)" as described from the Wielun Upland by Wierzbowski (1970) which belongs to the genus Vielunia (see Wierzbowski et al., 2010; Wierzbowski, 2017a). Possibly some other large specimens in the studied collection could also belong to that genus, but these are difficult for closer identification because of their poor preservation. They come both from the Bukowa Formation (the Piekielnica Coral Limestone Member, similarly as the discussed specimen) but also from the Małogoszcz Oolite Formation. It is noteworthy that the ammonites actually placed in the genus Vielunia were commonly attributed in the past to the genus Ringsteadia (e.g. Wierzbowski, 1970). However, the distinction between the genera Ringsteadia and Vielunia is based on morphological grounds (stronger development of secondary ribs, their appearance lower on the whorl side, and their persistence up to larger diameters in Vielunia), but also on the different type of their corresponding microconchs (Microbiplices versus Prorasenia) (see Wierzbowski et al., 2010, p. 70). There is also a marked difference in the stratigraphical distribution of these genera, because they follow each other in the uppermost Oxfordian/lowermost Kimmeridgian succession in NE European areas in a way somewhat parallel to that shown by the genera Ringsteadia and Pictonia in NW European areas (see e.g. Wright, 2010; Wierzbowski et al., 2016). Nevertheless, it is worth pointing out that the genus Ringsteadia smoothly evolved into the genus Vielunia, as in a similar fashion in a younger part of the succession Vielunia, represented either by stronger or weaker ornamented, and moderately or strongly involute groups of species, evolved into Eurasenia and Involuticeras. A gentle evolutionary transformation can result in some problems, when interpreting the systematic position of the specimens from the "transitional" stratigraphic interval. A similar situation is, however, commonly encountered in many ammonite lineages. This is related e.g. with the interpretation of the boundary between the last Pictonia and the first Rasenia in the NW European lineage of Aulacostephanidae (see Wright, 2010), and corresponds to the situation "where the boundaries between genera are purely arbitrary and represent no clearly discernible breaks in the morphological distribution of the groups as a whole" (Birkelund, Callomon, 1985, p. 30). In accordance with the aforegoing, the interpretation of Vielunia as a junior synonym of Ringsteadia, as recently postulated by Enay and Howarth (2019, p. 91), seems inappropriate both from phylogenetic as well as from stratigraphic points of view.

Other aulacostephanid ammonites of the discussed group are Involuticeras and Eurasenia commonly occurring in the south-western margin of the Holy Cross Mts., in the upper part of the Sobków Oolite Member ("upper oolite") and in the Celiny Onkolite Bed ("onkolite horizon") of the uppermost part of the Małogoszcz Oolite Formation. These are forms showing involute, and high oval whorl sections, and both of them are typical genera/subgenera of the NE Subboreal (or Submediterranean) lineage. Here belong such forms as Eurasenia vernacula (Schneid) (see Kutek, 1968, pl. 6: 1) recognized in the Celiny Oncolite Bed at Leśnica, showing a moderately involute coiling (at $\mathrm{D}=69 \mathrm{~mm}$, $\mathrm{Wh}=42, \mathrm{Ud}=29)$ and a strong ornamentation consisting of short and swollen primary ribs and fairly numerous secondaries (at $\mathrm{D}=70 \mathrm{~mm}, \mathrm{PR}=20-21, \mathrm{SR} / \mathrm{PR}=3.6$ ). Even more commonly encountered, however, are representatives of $I n$ voluticeras, showing generally a more involute coiling: more especially in I. involutum (Quenstedt) (Pl. 8: 1) at $\mathrm{D}=100-130 \mathrm{~mm}, \mathrm{Wh}=48.5-53.1, \mathrm{Ud}=17.8-23.4$, than in I. limbatum (Schneid) (Pl. 8: 2) at $\mathrm{D}=150 \mathrm{~mm}, \mathrm{Wh}=45-46$, $\mathrm{Ud}=27.6-30.8$, and a more dense ribbing from $\mathrm{PR}=20-22$ in the former, to $\mathrm{PR}=27-30$ in the latter. Moreover, the recognized species of Involuticeras coming from Sobków quarry as well as from the large Małogoszcz cement-works quarry, and the nearby Leśnica section attain often very large final sizes: I. involutum more than $200 \mathrm{~mm}$, I. limbatum even about $250 \mathrm{~mm}$ in final diameter (Pl. 9), which is close, or even above the maximum sizes of the representatives of these species known so far (Geyer, 1961).

Another group of the aulacostephanid ammonites is related to the NW European Subboreal lineage. Here belong such Early Kimmeridgian ammonites as Pictonia Bayle, 1878 and Rasenia Salfeld, 1913 (Pl. 6), representing the most typical representatives of the lineage, but also Pictonites Mesezhnikov, 1969, Pomerania Arkell, 1937 (Pls. 4, 5: 1) and Pachypictonia Schneid, 1940 (Pls. 5: 2; 7: 1, 2), which occur in Submediterranean as well as in NE European Subboreal areas, representing a special offshoot of the lineage as interpreted herein (see also Wierzbowski, 2017b).

A typical representative of the NW European Subboreal lineage is the unique specimen originally referred to as " $R a$ - 
senia (Eurasenia) pendula Schneid" by Kutek (1968, p. 555, pl. 11) from the lowermost part of the Małogoszcz Oolite Formation (Rogalów Limestone Member = "underlying pelitic limestones") at Rogalów in the south-western margin of the Holy Cross Mts. This specimen attains about $230 \mathrm{~mm}$ in final diameter, showing a body chamber about one whorl long, and the phragmocone/body chamber boundary at about $130 \mathrm{~mm}$ diameter. The coiling is at the evoluteness/ involutness boundary (at $\mathrm{D}=105 \mathrm{~mm}, \mathrm{Wh}=37, \mathrm{Ud}=38$; at $\mathrm{D}=160-230 \mathrm{~mm}, \mathrm{Wh}=37-38 ; \mathrm{Ud}=37-38)$, the ribbing is distant, represented by short bullate primaries (only in the innermost whorls the ribs are not bullate), which number per whorl oscillates from 19 at $\mathrm{D}=70 \mathrm{~mm}$, through $19-21$ at $\mathrm{D}=70-100 \mathrm{~mm}$, to 24 at $\mathrm{D}=157 \mathrm{~mm}$, and the secondaries appear fairly low on the whorl sides and are numerous (at $\mathrm{D}=110 \mathrm{~mm}, \mathrm{SR} / \mathrm{PR}=3.6$, at $\mathrm{D}=160 \mathrm{~mm}, \mathrm{SR} / \mathrm{PR}=4.0$ ). This specimen (Pl. 6) strictly corresponds to Rasenia inconstans Spath as described e.g. from East Greenland by Birkelund and Callomon [1985, p. 33-35, pls. 12: 1-4; 13: 1-5; 14: $1-4$; and see the relevant illustrations of the ammonites by Spath (1935), placed into the synonymy of the species]. It represents the earliest Rasenia species at the transition from older Pictonia into the NW European Subboreal lineage (e.g. Birkelund, Callomon, 1985). It is worth noting that the occurrence of large-sized specimens of Rasenia of NW European affinity has been recognized both in south-western France and northern Switzerland (Hantzpergue, 1989; Comment et al., 2015) in deposits corresponding to the lower part of the Subboreal Cymodoce Zone. The phylogeny of the Subboreal Aulacostephanidae in the NW European Subboreal province, including the genus Rasenia, was recently discussed by Wierzbowski A. et al. (2018).

The large-sized "megaconchs" of Pomerania and Pachypictonia occur fairly commonly in the south-western margin of the Holy Cross Mts. These ammonites were discovered by Kutek (1962a, b, 1968) in the vicinities of Rogalów, Małogoszcz, Mieronice and Sobków in deposits attributed herein to the upper part of the Bukowa Formation and to the Małogoszcz Oolite Formation, corresponding to the middleupper parts of the Platynota Zone - lowermost part of the Hypselocyclum Zone.

The older ammonites, such as Pictonia (Pomerania) dohmi (Arkell) and P. (P.) albinea (Oppel), exhibit the development of bullate primary ribs on the middle whorls. The species $P$. dohmi is represented by one well-preserved specimen described and illustrated by Kutek (1968, p. 561-563, pl. 9; see also Pl. 4) from the Krzyżowa Góra section at Małogoszcz, upper part of the Bukowa Formation (Leśnica Limestone Member = "the deposits overlying chalky limestones"), and by two other incomplete specimens referred to this species with reservation (see Kutek, 1968, p. 563), and coming from Rogalów quarry (Rogalów Limestone Member
= "underlying pelitic limestones"; Pl. 5: 1), and Sobków quarry (Głuchowiec Oolite Member = "lower oolite"), both corresponding to the lower part of the Małogoszcz Oolite Formation. The specimens even attain well above 250 $300 \mathrm{~mm}$ in final diameter as the largest of them is not complete, showing a partly preserved body chamber. They reveal evolute coiling in the middle whorls (at $\mathrm{D}=165-190 \mathrm{~mm}$, $\mathrm{Wh}=30-32, \mathrm{Ud}=43.0-44.5)$ and highly evolute coiling in the outer whorl (at $\mathrm{D}=220-300 \mathrm{~mm}, \mathrm{Wh}=27 / 28-30$, $\mathrm{Ud}=43-51)$. The ribbing on the inner whorls is composed of strongly prorsiradiate primaries, which become swollen on the middle whorls from about $120 \mathrm{~mm}$ diameter, where the short bullate strongly prorsiradiate primaries occur, whereas secondaries successively disappear; the outer whorl is covered with sparsely placed cuneiform single ribs. Number of primary ribs $(\mathrm{PR})$ on the inner-middle whorls grows from about 19 to 24 at $\mathrm{D}=60-150 \mathrm{~mm}$, and successively diminishes to about $20-21$ at $\mathrm{D}=170-200 \mathrm{~mm}$, and finally attains about $17-16$ ribs at $\mathrm{D}=270-300 \mathrm{~mm}$. The specimens discussed are closely comparable with the holotype of $\mathrm{Po}$ merania dohmi (Arkell) as based on the specimen of "Pictonia baylei' of Dohm (1925, p. 32, pl. 5: 6).

Another large specimen was interpreted as Pomerania albinea (Oppel) by Kutek (1968, p. 562-563, pl. 8: 3) and comes from Sobków quarry (Głuchowiec Oolite Member = "lower oolite" of the lower part of the Małogoszcz Oolite Formation). The specimens is about $290 \mathrm{~mm}$ in diameter, but it is not complete as shown by the partly preserved body chamber (the phragmocone/body chamber boundary is at $240 \mathrm{~mm}$ diameter). The coiling is evolute on the middle whorls (at $\mathrm{D}=105 \mathrm{~mm}, \mathrm{Wh}=31.5, \mathrm{Ud}=44.5$ ), but it becomes strongly evolute on the outer whorl (at $\mathrm{D}=275 \mathrm{~mm}$, $\mathrm{Wh}=28, \mathrm{Ud}=52$ ). The ribbing of the inner and partly middle whorls is not bullate, but soon thereafter, at about $150 \mathrm{~mm}$ diameter, bullate ribs appear. The secondary ribs in the inner/early middle whorls are 3-4 per one primary. On the outer whorl, the ribbing consists of single cuneiform primaries, whereas the ventral parts of the whorl become smooth. The number of primary ribs in the inner - middle whorls at $\mathrm{D}=55-150 \mathrm{~mm}$ is about $28-30$, then it markedly diminishes and attains $\mathrm{PR}=23$ at $\mathrm{D}=200 \mathrm{~mm}$, and $P R=13-14$ at $\mathrm{D}=275-290 \mathrm{~mm}$. The specimen in its inner whorls is closely comparable with Ammonites albineus as described and illustrated by Oppel [1863, pl. 50: 3a, b; see also Schneid (1940, pl. 6: 3, where the holotype is illustrated)], especially in the character of ribbing and type of coiling. It differs from $P$. dohmi (Arkell) in having a larger number of primary ribs in the inner whorls, and in the appearance of bullate ribs at a larger diameter.

Additionally, a few fragmentary specimens which can be referred to as Pictonia (Pomerania) sp., coming from the Leśnica Limestone Mbr. ("the deposits overlying chalky 
limestones") of the Bukowa Fm. at Głuchowiec quarry (see Kutek, 1962a, 1968), and the Głuchowiec Oolite Mbr. ("lower oolite") of the Małogoszcz Oolite Fm. at Sobków quarry, although specifically not determinable, show a similar morphology to the species described above.

Different morphology is shown by the specimens attributed to the genus Pachypictonia Schneid, 1940. All of them come from the Sobków Oolite Mbr. ("upper oolite") of the upper part of the Małogoszcz Oolite Fm. from Sobków quarry, thus they are younger than the above described Pictonia (Pomerania). According to Kutek (1968, p. 509), they occurred here commonly constituting about 50\% (11 specimens) of the whole number of collected ammonites. In the material studied they are represented by a few large specimens about 200-330 $\mathrm{mm}$ in diameter. The largest specimen shows a well-preserved ornamentation of the outer whorl consisting of extremely heavy cuneiform ribs, much stronger than those of the Pomerania species. This specimen illustrated by Kutek (1968, p. 564, pl. 10) reveals strongly evolute coiling of its outer whorl (at D $=330, \mathrm{Wh}=29$, $\mathrm{Ud}=48)$, and heavy and distant ribbing is present $(\mathrm{PR}=11)$. The ornamentation of the inner whorls is very poorly visible, but the presence of strong primary ribs can be noticed. This specimen seems similar to Pachypictonia peltata (Schneid). Another large specimen, about $206 \mathrm{~mm}$ in diameter shows strongly developed ribbing consisting of short, bullate primary ribs (at $\mathrm{D}=120 \mathrm{~mm}, \mathrm{PR}=25$ ). Its inner whorls are moderately evolute (at $\mathrm{D}=135, \mathrm{Wh}=30.4$, $\mathrm{Ud}=37.8$ ), but outer whorls are strongly evolute (at $\mathrm{D}=206 \mathrm{~mm}, \mathrm{Wh}=31.5, \mathrm{Ud}=43.2)$. This specimen (Pl. 5: 2) can be referred to as Pachypictonia cf. perornatula (Schneid).

Of some other specimens, the one with a hand-written label by Kutek "Pomerania (Pachypictonia) peltata" (Pl. 7: 2), is about $200 \mathrm{~mm}$ in diameter (at least with some parts of the body chamber preserved), shows moderately evolute coiling (at $\mathrm{D}=196 \mathrm{~mm}, \mathrm{Wh}=36.2, \mathrm{Ud}=38.2$ ), and the presence of strong cuneiform ribs on the outer whorl $(P R=16)$. The ornamentation fragmentarily discernible on its inner whorls is very strong, consisting of short primaries, as well as secondaries, with a low point of the rib division, and a rather low secondary/primary ribs ratio (at $\mathrm{D}=130 \mathrm{~mm}, \mathrm{SR} / \mathrm{PR}=3.0$ ). Still another fragmentarily preserved specimen described as "Pomerania (Pachypictonia) sp." (P1. 7: 1) by Kutek shows loosely placed, short, bullate primary ribs, and wide-spaced, not numerous secondaries; this specimen shows a low-oval whorl section, and its coiling is near the evoluteness/involuteness boundary (at D about $120 \mathrm{~mm}, \mathrm{Wh}=\mathrm{Ud}=37.5$; at $\mathrm{D}$ about $90 \mathrm{~mm}, \mathrm{Wh}=\mathrm{Ud}=33.3$ ). These specimens show an ornamentation similar to "Rasenia" trifurcata (Reinecke) placed in the subgenus Eurasenia by Geyer (1961), but are possibly closely related to the German Pachypictonia (Birkelund, Callomon, 1985).
All these data indicate a close phylogenetic relationship between Pomerania and Pachypictonia, but the problems of the development of the lineage in question in the Submediterranean areas/ NE European Subboreal areas from its very beginning, as well as its relation to typical NW European Subboreal aulacostephanids, need detailed discussion (see also Wierzbowski, 2017b).

The first new ammonite preceding the appearance of Pomerania was possibly Pictonia perisphinctoides (Wegele), being close to another Submediterranean Pictonia species $-P$. thurmanni (Contejean), both of them representing immigrants from the NW European Subboreal areas (see Hantzpergue, 1989; Schweigert, Callomon, 1997). These ammonites are known from the Submediterranean Planula Zone in southern Germany and central Poland, from the Wieluń Upland (Schweigert, Callomon, 1997; Wierzbowski, 2017a), which may be correlated with some parts of the Normandiana Subzone of the upper part of the Subboreal Baylei Zone. The special feature of Pictonia perisphinctoides is probably the coarse curved triplicate ribbing of the outer whorl which is, however, poorly visible in the holotype of the species, originally described as "Rasenia" perisphinctoides by Wegele from southern Germany (1929, pl. 10: $2 \mathrm{a}, \mathrm{b})$, because of its fairly small size. Such ribbing is well seen in another specimen of Wegele (1929, pl. 10: 1a, b) originally referred to as "Rasenia dacquei", and treated for a long time as a separate species, but which represents the outer whorl of a form close to $P$. perisphinctoides (see Schweigert, Callomon, 1997, p. 45; see also Wierzbowski, 2017a, p. 81). A similar development of the ornamentation on the outer whorl is shown by another, somewhat younger, species of Pictonia of the same lineage described as Pictonia kuyaviensis Matyja et Wierzbowski, from the Barcin area in northern Poland; it is represented by small-sized specimens and a fragment of the outer whorl referred originally to "Rasenia aff. daquei " by Matyja, Wierzbowski (2002, P1. 1: 4-11, 12) from the Galar Subzone. These ammonites of the genus Pictonia reveal thus special features somewhat different from those of the nominative subgenus, and deserve a separate subgenus name. Such was the original proposal of Mesezhnikov (1969), who distinguished the name Pictonites with the type species - Pictonia (Pictonites) perisphinctoides (Wegele) for the evolute forms from southern Germany, showing fairly regular ornamentation which continues on the outer whorl.

On the other hand, the ammonite "Rasenia daquei " of Wegele (1929, pl. 10: 1a, b) has been placed by Geyer (1961, p. 118) in the synonymy of "Pictonia indicatoria" Schneid (1940, p. 90, pl. 8: 1-4), which is the type species of the subgenus Pachypictonia Schneid, 1940 as recognized in southern Germany. This interpretation is, however, inappropriate ( $c f$. Schweigert, Callomon, 1997), not only for the 
reason given above, but also because the inner whorls of Pachypictonia indicatoria show already at small diameters the presence of swollen stout primary ribs different from those occurring at comparable diameters in Pictonia (Pictonites) perisphinctoides.

The crucial aspect of any proposal that is considered to explain the relation between Pictonia (Pictonites) and Pachypictonia is strictly related with the recognition of the phylogenetical position of the somewhat enigmatic taxon Pomerania Arkell, 1937. The ammonites originally described by Dohm (1925) from the Upper Jurassic of western Pomerania, in the quarry at Czarnogłowy (Zarnglaff), were compared by him with the genus Pictonia. Such an interpretation was questioned by Arkell (1937), who introduced a new name Pomerania (with the type species Pomerania dohmi as based on specimens attributed by Dohm to the species Pictonia baylei - see Dohm, 1925, p. 32, pl. 5: 6), and proposed it as a new subgenus of the genus Decipia. Although there exists some similarity in ornamentation of the middle and outer whorls between Decipia and Pomerania, the stratigraphical position of these two ammonite taxa are quite different. Geyer (1961) recognized that the Lower Kimmeridgian ammonites placed in the genus Pachypictonia by Schneid (1940) are related to the genus Pomerania, and distinguished provisorily the genus Pomerania with two subgenera Pomerania and Pachypictonia, indicating the relation of the former with the genus Pictonia, and the latter with the genus Rasenia. A similar opinion was expressed also by Kutek (1968) when studying the material from the south-western margin of the Holy Cross Mts. On the other hand, Enay and Howarth (2019), when giving the classification of the family Aulacostephanidae, recognized the separate genus Pachypictonia, but treated the assignment of the genus Pomerania to Aulacostephanidae as still disputable.

However, it should be remembered that there exist strong resemblances between Pomerania and Pictonia (Pictonites) indicating their close affinity, but the main difference is in the character of the outermost whorls of Pomerania which bear bold coarse single, straight or wedge-shaped ribs on the body chamber at larger diameters. These observations suggest that the name Pictonites Mesezhnikov, 1969 could be treated either as a junior synonym of Pomerania Arkell, 1937, or the two names correspond to morphs somewhat different in their final growth - the former attaining maturity earlier than the latter. Thus, the names PomeraniaPictonites should be considered as subgenus/era of Pictonia.

There exist a number of species, which may be placed in the subgenus/era Pomerania-Pictonites as described mostly by Schneid (1940) from southern Germany. Some of them were subsequently described also from Switzerland and central Poland (Kutek, 1968; Gygi, 2003), thus showing their wide distribution in the Submediterranean areas. In the same areas have also been described species attributed to Pachypictonia as originally distinguished on the basis of Pachypictonia indicatoria Schneid (see Schneid, 1940, pl. 8: 1-3) which differ from those of the Pictonites-Pomerania type in their having markedly stronger and swollen primary ribs in the inner whorls. Thus, the two taxa should be treated separately - the former as corresponding to the independent genus Pachypictonia, the latter as the subgenus/era of Pictonia. Both of them occur commonly in the NE European part of the Subboreal Province (Dohm, 1925 - see also comments below; Głowniak et al., 2010).

As was shown in the material studied from the Holy Cross Mts., the ammonites of the genus Pictonia (Pomerania) occur mostly in somewhat younger deposits (i.e. Platynota Zone) than those which yield Pictonia (Pictonites) (i.e. Planula Zone), which confirms additionally for the time being the application of both the Pictonites and Pomerania names to the two different morphotypes which may be distinguished at the subgenus level. It is not excluded that during the evolution of the lineage in question - after dominance of the Pictonites forms, the appearance of successively larger, and attaining later maturity macroconchs of the $\mathrm{Po}$ merania type has been attained. On the other hand, a gentle succession from the Pomerania to Pachypictonia macroconchs without any discernible breaks in morphology is generally recognized, as these forms replaced each other from the Submediterranean middle to upper Platynota Zone to the lowermost Hypselocyclum Zone. This is especially well-marked in the material studied from the south-western margin of the Holy Cross Mts., where from the transition between the lower and middle parts to the upper part of the Platynota Zone occur species like Pictonia (Pomerania) dohmi (Arkell) and P. (P.) albinea (Oppel), showing the appearance of bullate ribs on the middle whorls. Their smooth evolutionary transition to Pachypictonia towards the top of the Platynota Zone resembles that from Pictonia to Rasenia in the main lineage of the Aulacostephanidae in NW European areas ( $c f$. Birkelund, Callomon, 1985). The end of the Early Kimmeridgian marked possibly the decline of the side-lineage in question in the area of study which was possibly related to the change in sea-current circulation as well as the disappearance of the central European zone of shallowwater carbonate deposits interfingering with the clastic influx of the so-called "European Archipelago" constituting the main area of the Subboreal Province, which was the area of development of Aulacostephanidae ( $c f$. Fürsich, Sykes, 1977). 